\title{
1987 Annual Report on
}

\section{Alaska's Mineral Resources}

\section{U.S. GEOLOGICAL SURVEY CIRCULAR 1012}

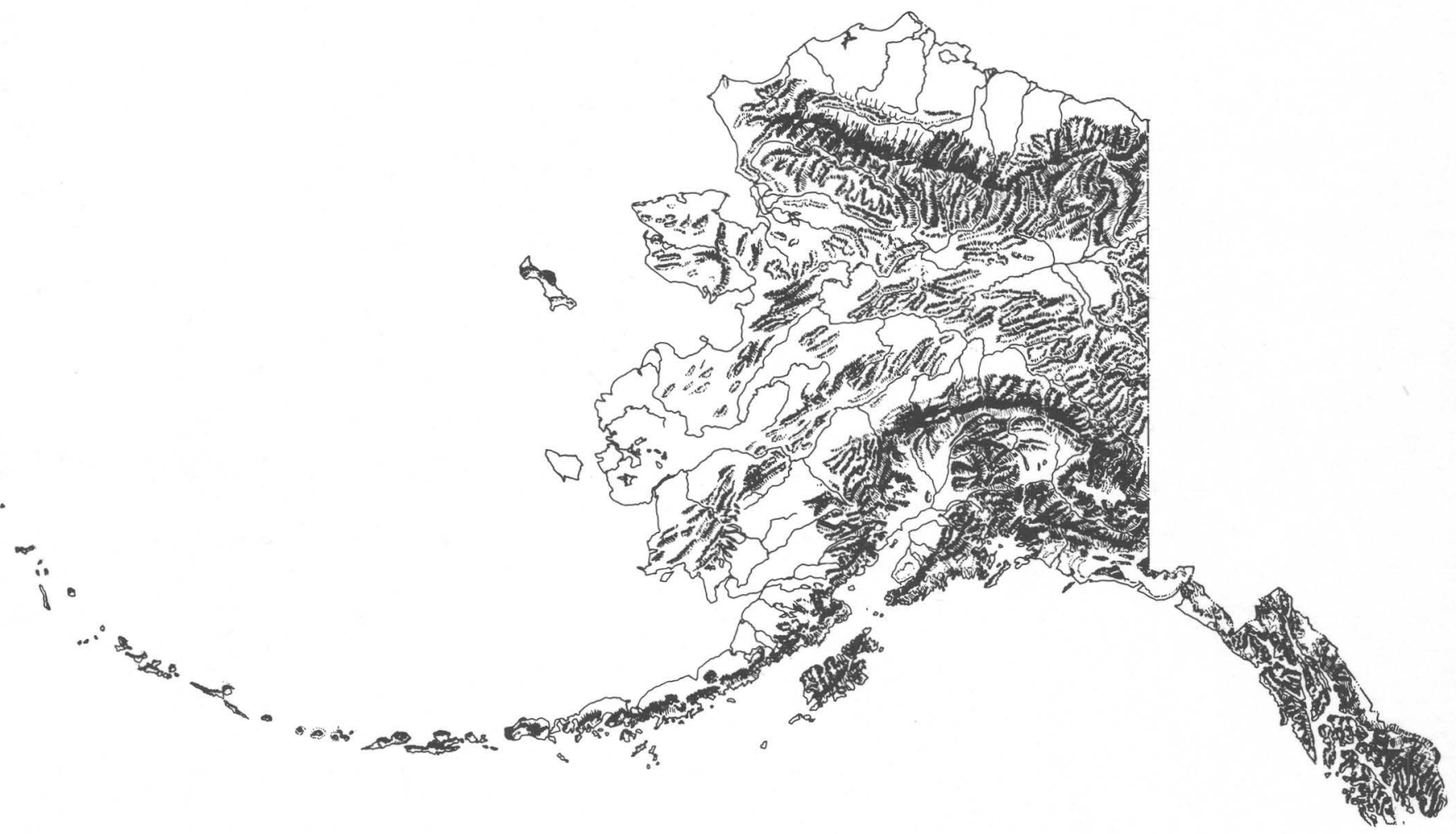

Prepared in cooperation with

the Bureau of Land Management,

the Fish and Wildife Service,

the National Park Service, the

U.S. Bureau of Mines, the U.S.

Forest Service, and the Department

of Energy, as mandated by Section 1011

of the Alaska National Interest Lands

Conservation Act, Public Law 96-487,

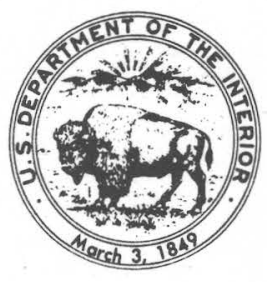

of December 2, 1980 


\title{
Contributors
}

\author{
Department of the Interior \\ Bureau of Land Management \\ Reed Smith \\ Fish and Wildlife Service \\ Ann Rappoport \\ National Park Service \\ Cordell Roy \\ U.S. Bureau of Mines \\ Donald P. Blasko \\ U.S. Geological Survey \\ Max Brewer \\ Kendell Dickinson \\ Bruce Gamble \\ Norman Scott III \\ Gary Stricker \\ M. Elizabeth Yount \\ Department of Agriculture \\ U.S. Forest Service \\ Roger Griffin \\ Department of Energy \\ William Gwill iam \\ Rodney Malone \\ Marshall Reed \\ Harold Shoemaker
}

Frontispiece, facing page

Solomon Gulch near Valdez--site of the Midas mine, an iron-copper-zinc-lead deposit being studied by the U.S. Geological Survey. Photograph by S.W. Nelson. 


\title{
1987 Annual Report on
}

\section{Alaska's Mineral Resources}

\author{
DIEDRA BOHN, Editor
}

\section{U.S. GEOLOGICAL SURVEY CIRCULAR 1012}

Prepared in cooperation with the Bureau of Land Management, the Fish and Wildlife Service, the National Park Service, the U.S. Bureau of Mines, the U.S. Forest Service, and the Department of Energy, as mandated by Section 1011 of the Alaska National Interest Lands Conservation Act, Public Law 96-487, of December 2, 1980

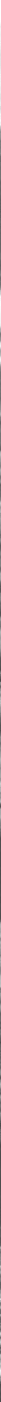




\section{DEPARTMENT OF THE INTERIOR \\ DONALD PAUL HODEL, Secretary}

U.S. GEOLOGICAL SURVEY

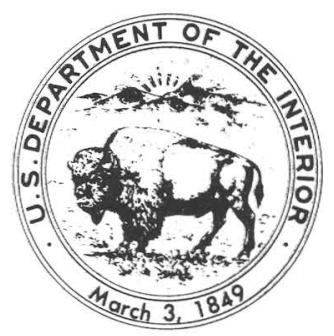

Dallas L. Peck, Director

Library of Congress Cataloging-in-Publication Data:

Annual report on Alaska's mineral resources. 1982-[Reston, Va.]: Dept. of the Interior, U.S. Geological Survey. [1982-

v. : maps; $26 \mathrm{~cm},--$ (U.S. Geological Survey Circular) Annual.

"As mandated by Section 1011 of the Alaska National Interest Lands Conservation Act, Public Law 96-487, of Dec. 2, 1980."

Supt. of Docs. no.: 1 19.4/2:

GP0: Item 620-A

ISSN 8755-0709 = Annual report on Alaska's mineral resources.

1. Mines and mineral resources--Alaska--periodicals. 1. U.S. Geological Survey. 11. Series: United States. Geological Survey Circular 1012. TN24.A4A66 533'.09798-de19 86-642168 AACR 2 MARC-S Library of Congress [8604]

Free on application to the Books and Open-File Reports Section, U.S. Geological Survey, Federal Center, Box 25425, Denver, C0 80225 


\section{CONTENTS}

Summary

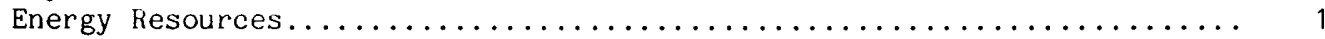

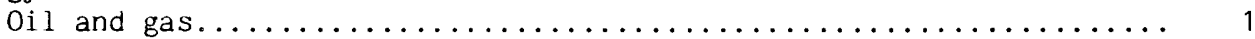

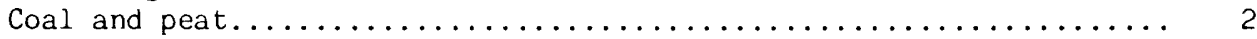

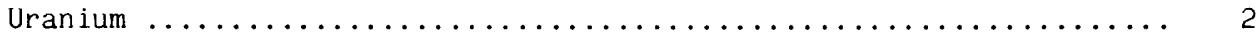

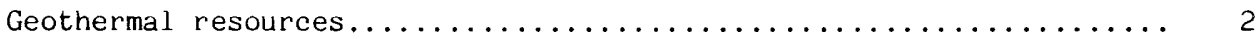

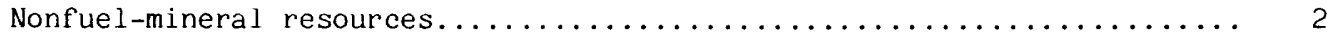

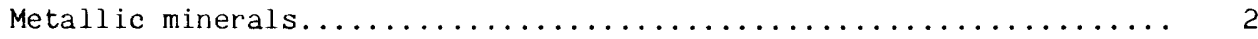

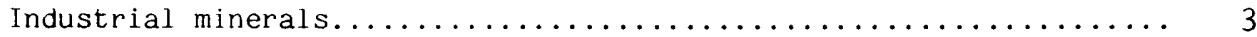

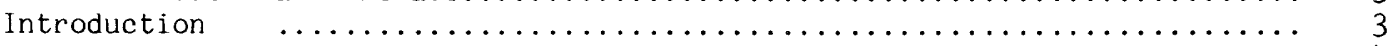

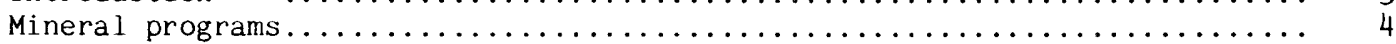

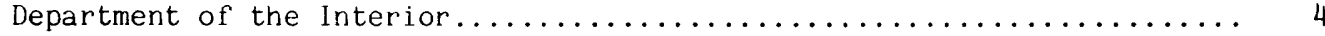

U.S. Geological Survey ............................ 4

U.S. Bureau of Mines............................. 4

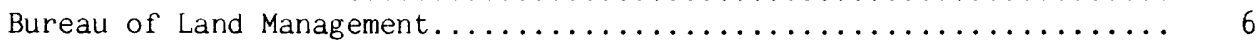

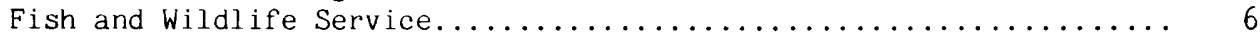

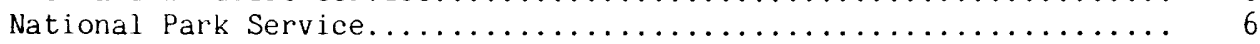

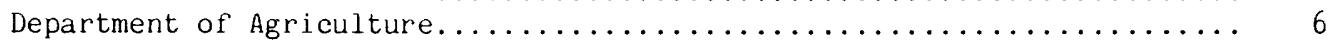

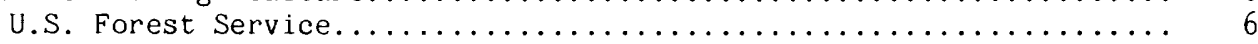

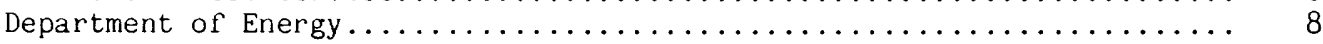

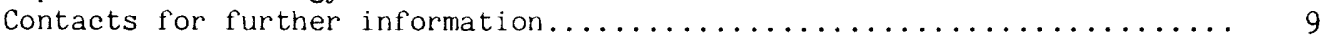

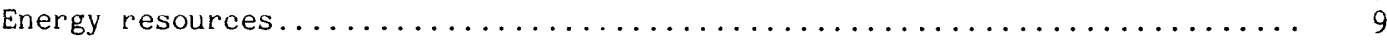

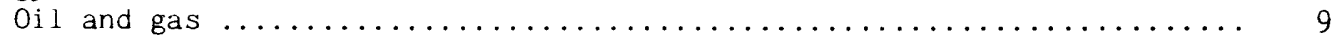

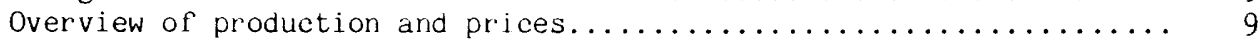

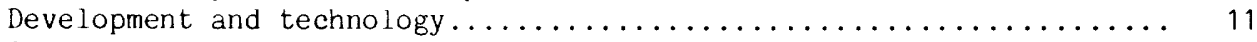

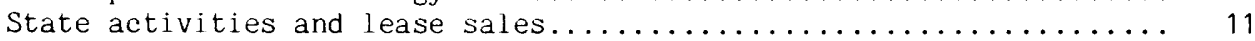

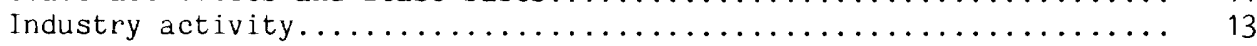

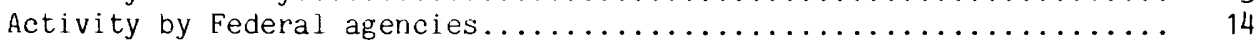

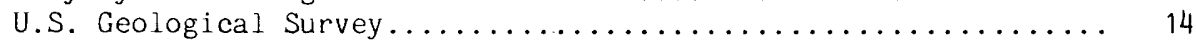

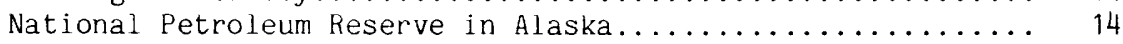

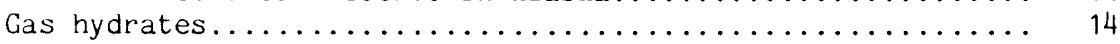

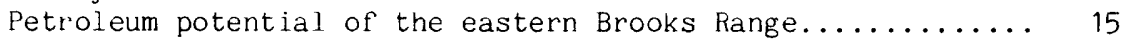

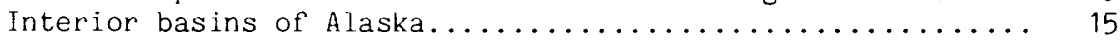

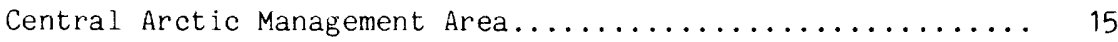

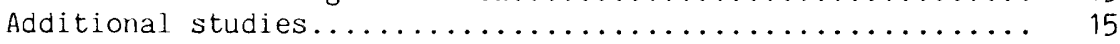

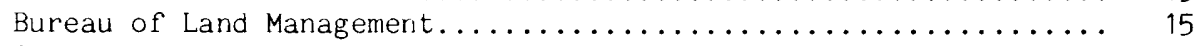

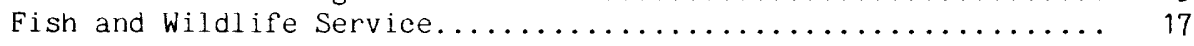

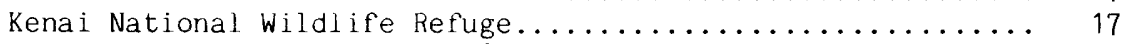

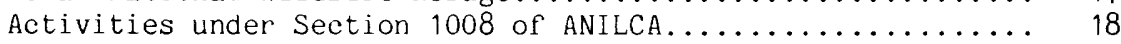

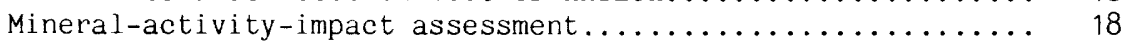

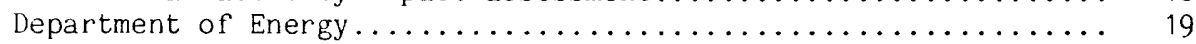

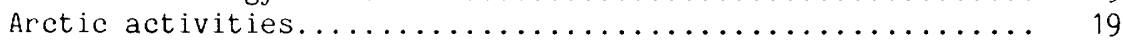

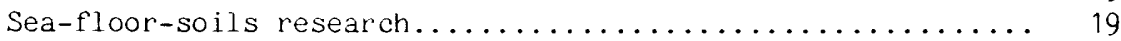

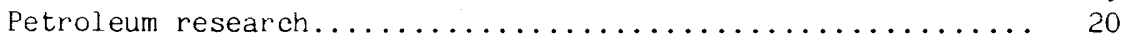

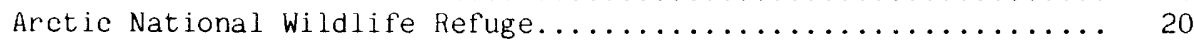

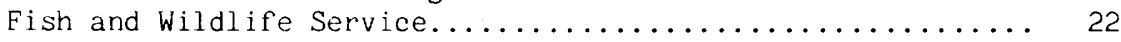

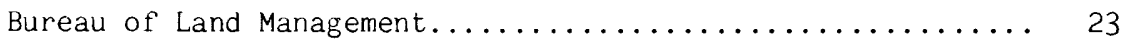

U.S. Geological Survey........................ 23

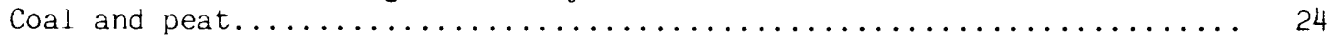

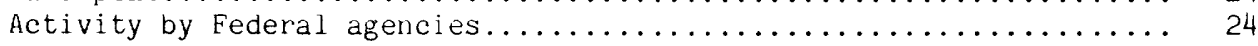

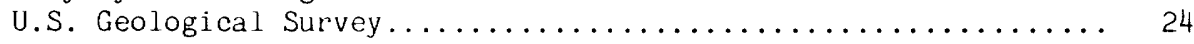

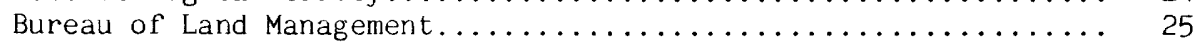

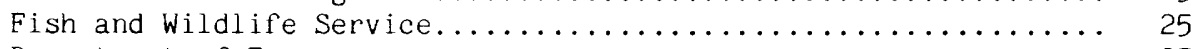

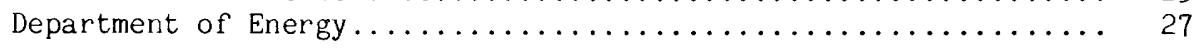




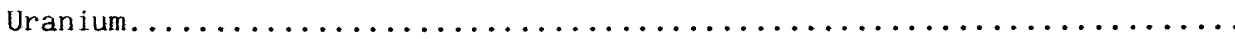

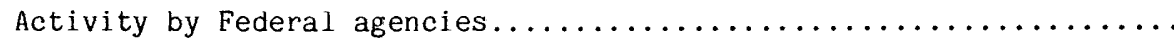

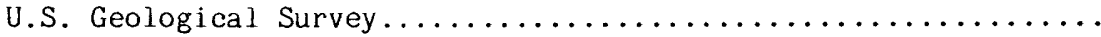

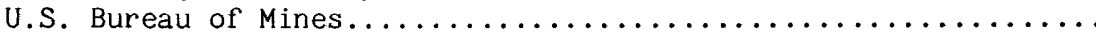

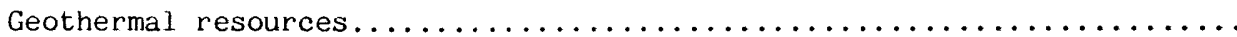

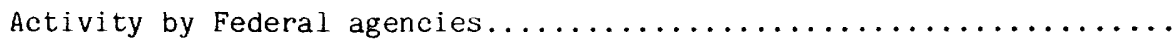

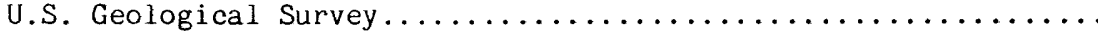

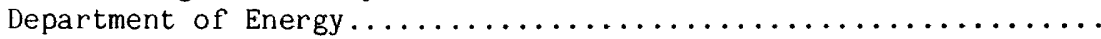

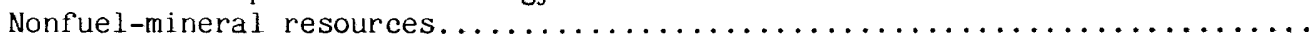

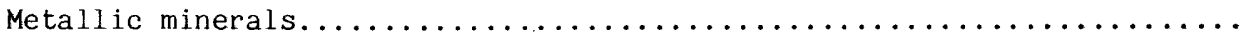

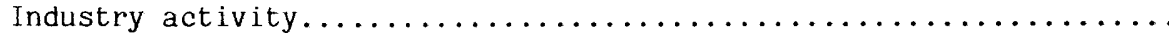

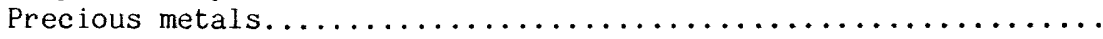

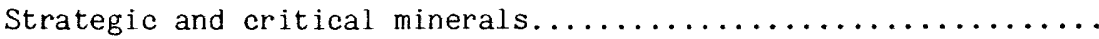

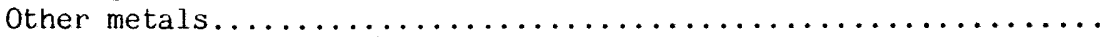

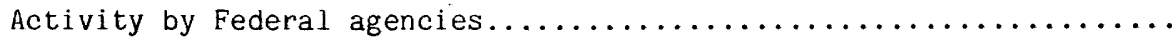

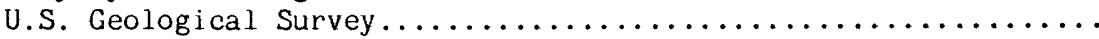

Alaska Mineral Resource Assessment Program..............

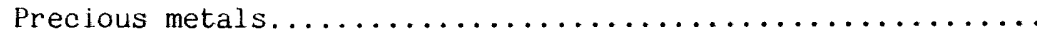

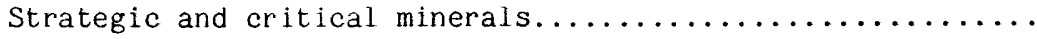

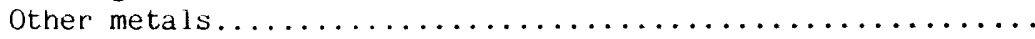

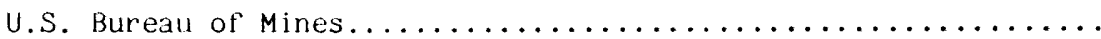

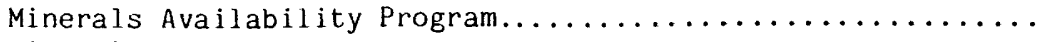

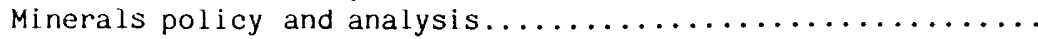

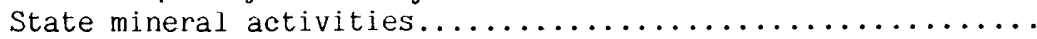

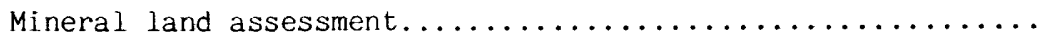

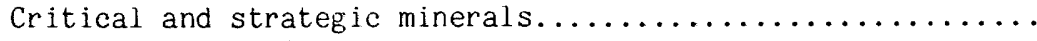

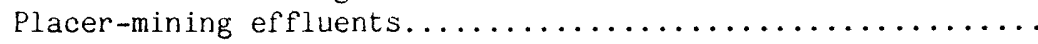

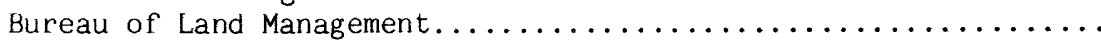

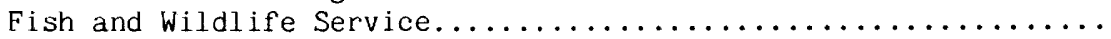

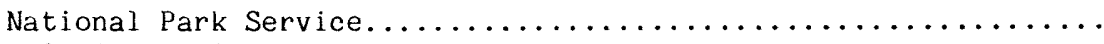

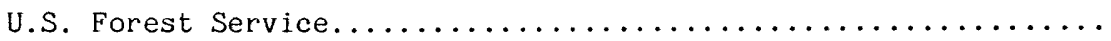

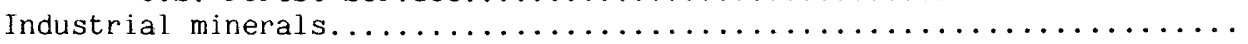

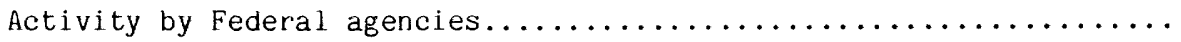

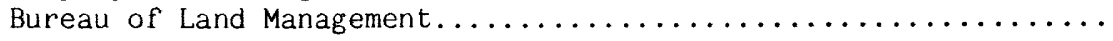

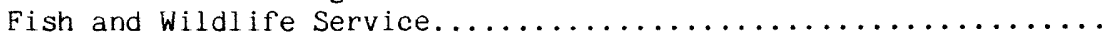

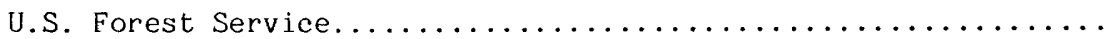

References cited

Appendix 1.--Alaska mineral reports released during 1986 and early

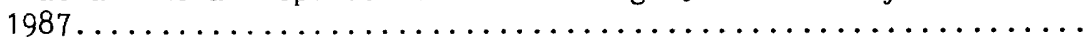

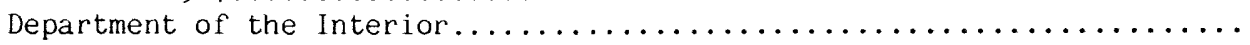

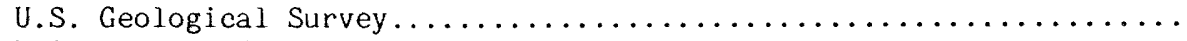

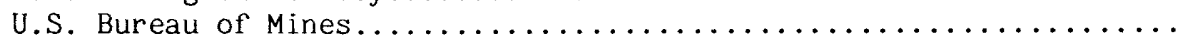

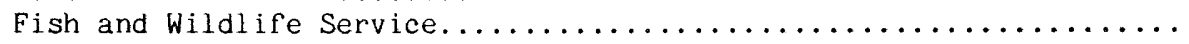

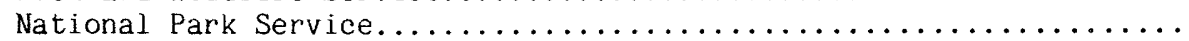

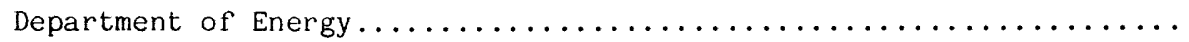

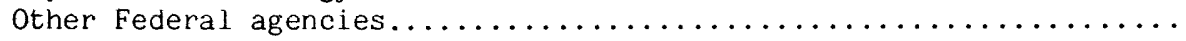

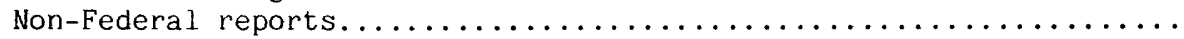

Alaska Division of Geological and Geophysical Surveys..........

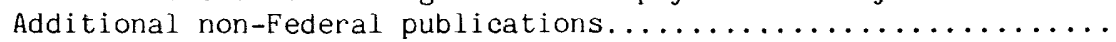

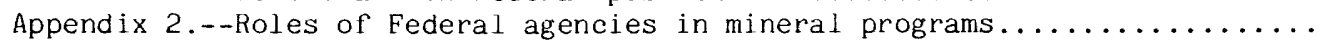

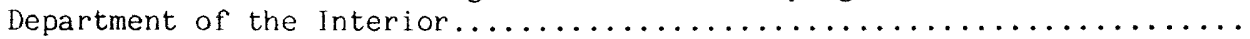

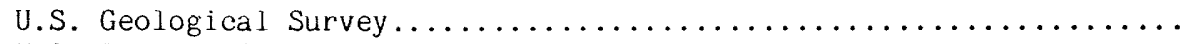

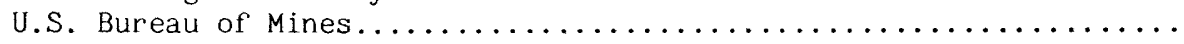

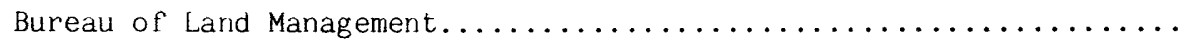

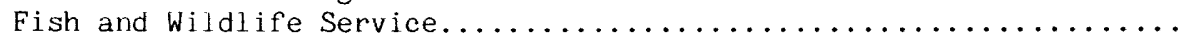

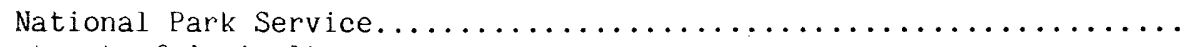

Department of Agriculture. . . . . . . . . . . . . . . . . . . . . .

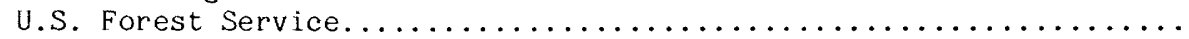

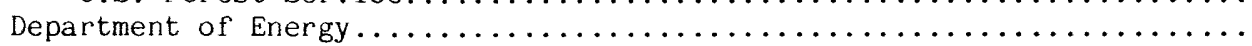




\section{ILLUSTRATIONS}

Figures 1-2. Maps showing:

Page

1. Federal land ownership in Alaska................ 5

2. National wildl ife refuges in Alaska............... 7

3. Photograph of Mount Spurr, one site of Department

of Energy-sponsored geothermal research.............. 8

4. Map showing locations of exploratory wells, oil and gas

fields, and possible petroleum-bearing onshore sedimentary basins............................. 10

5. Graph of total U.S. oil production and the price of oil

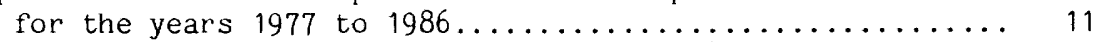

6-7. Maps showing:

6. Areas of oil and gas lease sales................. 12

7. Onshore Favorable Petroleum Geological

Provinces, land units referred to in text, and locations of Department of Energy-funded

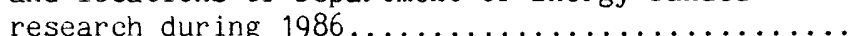

8. Photograph of the 1002 area, Arctic National

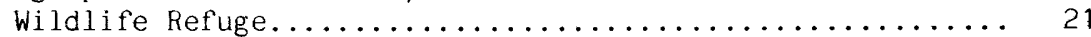

9. Map showing location of the 1002 area, Arctic

National wildlife Refuge........................ 21

10-12. Photographs of:

10. A musk ox, Aretic National Wildlife Refuge......... 22

11. U.S. Geological Survey geologists examining coal cores at the Sagwon Bluffs on the North Slope..... 25

12. A coal geologist at Usibelli Coal Mine, Inc......... 25

13. Map showing areas of potential coal and peat, uranium,

and geothermal resources........................ 26

14-16. Photographs of :

14. Emmons Lake caldera, subject of

U.S. Geological Survey geothermal research....... 28

15. Klawasi mud volcano, target of Department

of Energy-sponsored geothermal research.............. 28

16. The Bima, a new of fshore gold dredge in the Nome area........ 29

17-18. Maps showing:

17. Areas of significant industry activity for metallic minerals (excluding uranium) in 1986, and mine locations referred to in text............... 30

18. Location of U.S. Geological Survey metallic-mineral

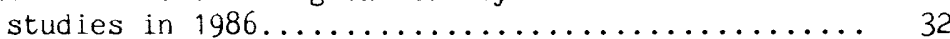

19. Map showing status of level III Alaska Mineral

Resource Assessment Program studies, February 1987........

20-21. Photographs showing:

20. U.S. Geological Survey geologist at an hydraulic

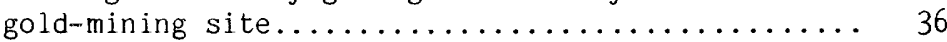

21. Rocks in the Midas mine near Valdez............... 36

22-23. Maps showing:

22. Locations of minerals on the U.S. Bureau of Mines Minerals Availability System (MAS) data base

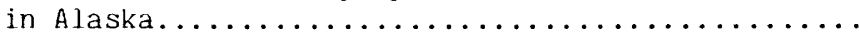

23. Locations of U.S. Bureau of Mines studies of mining districts and critical and strategic minerals

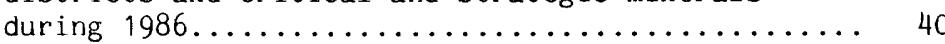

24. Photograph of U.S. Bureau of Mines geologists sampling

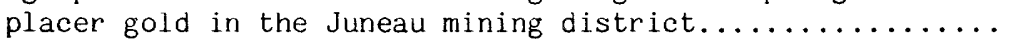


TABLES

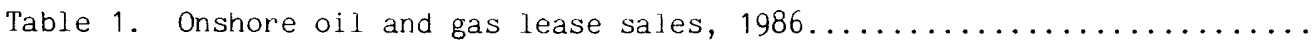

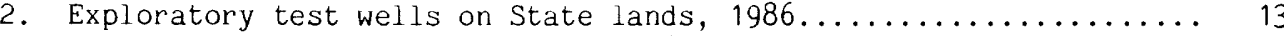

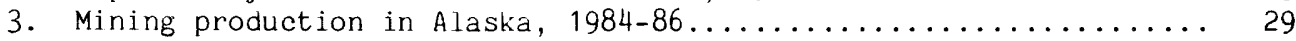

4. Level IV studies of the Alaska Mineral Resource Assessment

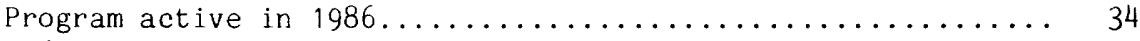

5. Areas of U.S. Bureau of Mines activity in mining districts and critical and strategic minerals in 1986.

Any use of trade names and trademarks in this report is for descriptive purposes only and does not constitute endorsement by the U.S. Geological Survey. 


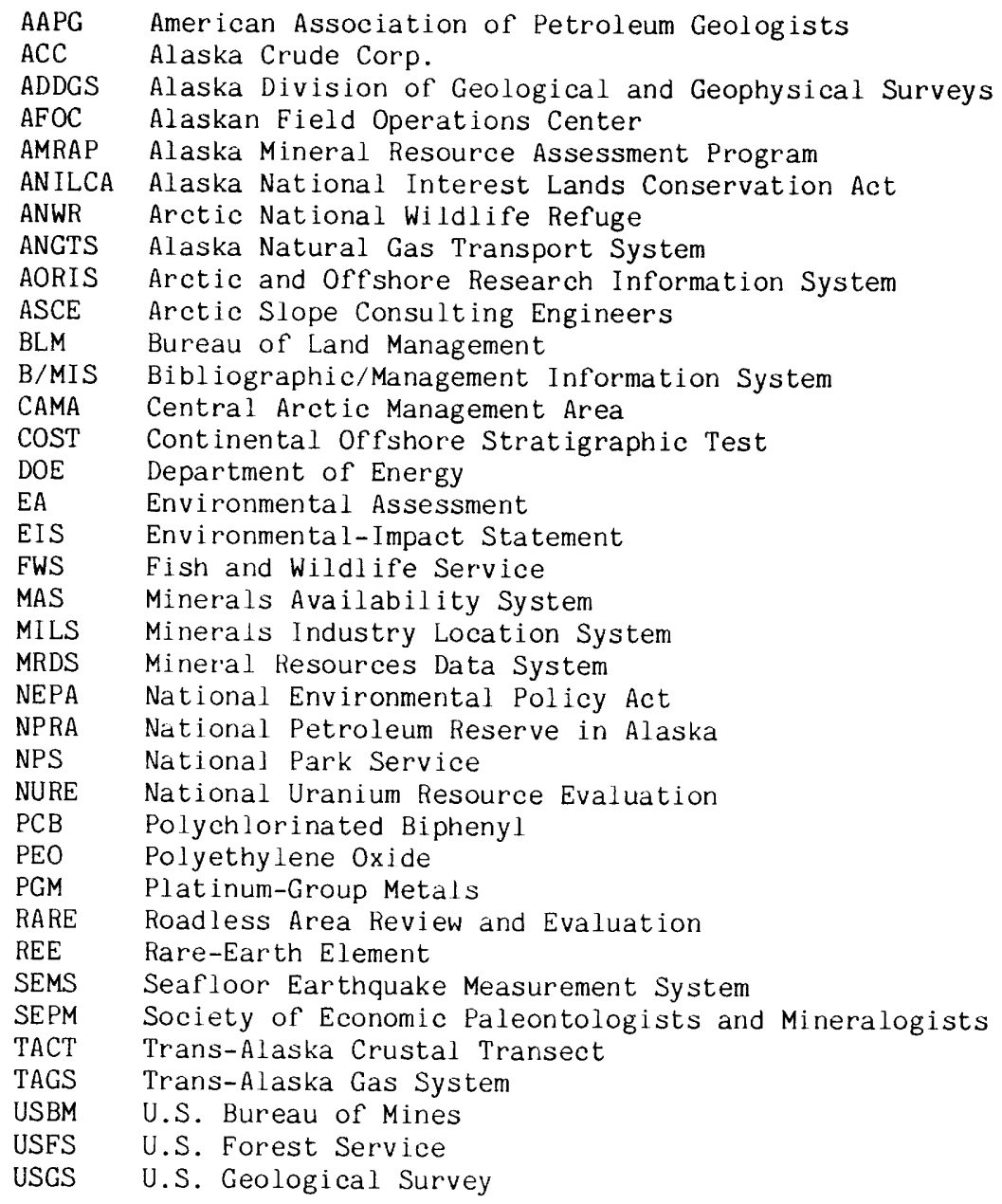





\title{
1987 Annual Report on Alaska's Mineral Resources
}

\author{
Diedra Bohn, editor
}

\section{SUMMARY}

Section 1011 of the Alaska National Interest Lands Conservation Act (ANILCA) of 1980 requires that "On or before October 1, 1982, and annually thereafter, the President shall transmit to Congress all pertinent public information relating to minerals in Alaska gathered by the United States Geological Survey, Bureau of Mines, and any other Federal agency." This report has been prepared in response to that requirement.

The U.S. Geological Survey (USGS) and the U.S. Bureau of Mines (USBM) are the principal Federal agencies that publish information about mineral resources in Alaska. Their reports and data are commonly used by other Federal agencies in decisionmaking on land use, access, environmental impacts, and claim evaluation. Because of the time required for sample analysis, data synthesis, and the publication process, scientific reports are generally issued a year or more after the initial sample and data collection. Other sources of information include Federal and State publications, trade and professional journals, newspaper articles, presentations at public meetings and hearings, and press releases.

This Circular is the sixth in a series of annual ANILCA reports. The report provides information about current Alaskan mineral projects and events during 1986 and in the early months of 1987; the emphasis is on Federal activity. In general, the report addresses only onshore areas of Alaska. Information is provided for two broad categories of minerals: energy resources and nonfuel-mineral resources.

\section{ENERGY RESOURCES}

\section{Oil and Gas}

The oil industry in Alaska was severely stressed by the rapid fall in the price of domestic crude oil during 1986 . The far-reaching effects on the State's oil-based economy had implications for most aspects of life in Alaska, including markedly increased unemployment and decreased construction activities. Declining oil prices crippled the State government, which collects 85 percent of its revenue from royalties and taxes on oil production. Industry responded to the drastic fall in oil prices by tightening budgets and reducing the number of employees. Operations ceased at the 1 year-old Milne Point field on the North Slope by the end of the year.

Oil production increased slightly in Alaska during 1986, in spite of the decline in market value. Alaska continues to rank second among the oil-producing States, and supplies approximately 20 percent of domestic oil production. Proportionally more oil was produced from North Slope fields as production levels fell in the Cook Inlet area. By September, oil production was estimated to have reached the halfway point for recoverable reserves from the Prudhoe Bay field. Eight new exploratory wells were drilled on the North Slope during the year. Also on the North Slope, industry further developed two promising technologies: horizontal drilling and manmade ice islands.

Three competitive onshore oil and gas lease sales held by the State during 1986 attracted $\$ 3.9$ million in high bids for 704,000 acres of land.

Energy-resource studies by the USGS concentrated on the North Slope of Alaska, including a compilation of technical papers on the National Petroleum Reserve in Alaska (NPRA), research on natural-gas hydrates, and an assessment of the petroleum potential of the central North Slope area. South of the Brooks Range, the USGS continued research on the petroleum potential of the sedimentary basins in interior Alaska, and released a volume of reports related to the drilling of a well in Cook Inlet.

The Bureau of Land Management (BLM) continued its oil and gas leasing program on three areas south of the Brooks Range but postponed a lease sale in the NPRA, owing to low demand. The BLM also provided the Fish and Wildlife Service (FWS) with petroleum assessments for four national wildlife refuges by June 1987, and continued cooperative oil and gas studies with the USGS on lands of the central North Slope.

In keeping with its mission to protect fish, wildlife, and habitat, the FWS monitored and evaluated the environmental impact of existing 
petroleum-related activities, and proposed development on several national wildlife refuges.

Continuing Arctic and offshore research by the Department of Energy (DOE) in 1986 included expansion of a computerized data base of Arctic energy-related technical information, coordination and funding of interagency studies, and research on recovery techniques for Arctic petroleum. The DOE also sponsored new technological studies on gas hydrates (a solid, icelike form of gas) and deep-source gas (from depths greater than 30,000 ft).

Arctic National Wildlife Refuge.--During 1986, the draft report and recommendations to Congress and the legislative environmental-impact statement (EIS) on the Arctic National Wildlife Refuge (ANWR) coastal-plain resource assessment were published; the final report was released in April 1987. This report marks the culmination of several years of geologic, geophysical, wildlife, wilderness, and subsistence studies by the FWS, BLM, and USGS.

\section{Coal and Peat}

In 1986, Alaskan coal was the fourth most valuable mineral commodity in the State, and production increased by 9 percent over 1985 output. However, a decline in the price for Alaskan coal resulted in only a minimal economic gain over the previous year's value. The demand for peat, used primarily in urban areas for horticultural applications, dropped sharply along with the plunge in housing construction.

All of the 1986 Alaskan coal production came from one coal mine in central Alaska, owned by Usibelli Coal Mine, Inc., southwest of Fairbanks. Half of their production was exported to Korea, and the rest was sold for instate heating and fuel needs. Other industrial activity centered on resource-quality investigations and marketing strategies for coal from the Beluga, Healy, and Jarvis Creek fields. If plans for a coal-fired powerplant in Alaska and proposed exports to Pacific Rim countries are successful, Alaskan coal production will increase in the near future.

During 1986, State of Alaska geologists continued a promising investigation of coal deposits for local use by village residents of the Seward Peninsula.

Federal activity related to coal included research, leasing management, and an assessment of coal development's environmental impact. The USGS continued research into the quality and chemical composition of coals statewide. USGS projects included assessments of the resources in the very large Northern Alaskan coal field, the petroleum-source potential of coals near Healy, the geochemistry of Usibelli coal, and the quality of the State's thickest-known coal seam on the Seward Peninsula. Interest in the BLM coal-leasing program is low at this time, and only one lease was active during the year. The FWS provided information related to environmental concerns for planned coal development on Native inholdings within the NPRA. Research funded by the DOE included a study of liquefaction of Alaskan coals by the University of Alaska.

\section{Uranium}

Most U.S. uranium producers cannot compete at the price of imported uranium, and so there is little uranium exploration activity nationwide and particularly in Alaska, with its high exploration and production costs.

Uranium studies by Federal agencies were minimal during 1986. The USBM released a report on an investigation of the uranium source for the Death Valley prospect on the Seward Peninsula.

\section{Geothermal Resources}

There are many potential geothermal-energy sources from the numerous volcanoes in Alaska, but few source areas are close to existing powertransmission networks. Mount Spurr, near Anchorage, is an exception. In 1986, the State of Alaska competitively leased two geothermal tracts totaling 2,628 acres near Mount Spurr. The mountain was also studied for its geothermal potential in a cooperative project by State and university geologists, funded by the DOE.

On the Alaska Peninsula east of Cold Bay, the USGS began geologic studies to define the geothermal potential of Emmons Lake caldera. Although the USGS continues many other investigations of active volcanoes in Alaska, the remoteness of most of the site locations limits potential geothermal-resource development.

\section{NONFUEL-MINERAL RESOURCES}

\section{Metallic Minerals}

Activity in Alaskan metallic minerals during 1986 declined significantly from previous years. In a report on Alaska's mineral industry in 1986, Bundtzen and Green (1987) report that expenditures for finding, developing and producing Alaskan minerals fell 14 percent, while the number of people employed through mining dropped by 19 percent.

The greatest decrease in mining activity was in placer gold mining, as one-sixth of the claims active in 1985 ceased operations. A full 22 percent fewer new claims were filed in 1986 than 1985. Contributing to the decline in placer mining is recent concern about compliance with State water-quality standards. According to Bundtzen and Green, 30 mining operations employing 175 people were temporarily halted by litigation affecting 3 units of the national park system. A lawsuit filed against the BLM threatened to shut 
down operations at an estimated 242 mines, but an out-of-court settlement on the temporary restraining order was reached before the mining season began.

For lode deposits, the rising dollar value for gold offset the 16-percent decline in Alaskan gold production for 1986. Gold production valued at $\$ 60.8$ million accounted for 98 percent of the Alaskan metals market. Tin, silver, antimony, tungsten, and mercury constitute the rest of that market, of which only tin showed an increase in production and value during 1986. The only mining of platinum in the United States continued in 1986 at Goodnews Bay, Alaska; production statistics are held confidential. As prices for zinc and lead began to rise in late 1986, development plans for the Red Dog zinc-lead-silver deposit in northwestern Alaska centered on port construction and road development. The lead-zinc-silver-gold deposit at Greens Creek in southeastern Alaska awaits development approval by the new owners.

Federal activity in Alaskan metallic minerals ranged from research to regulatory functions. The results of studies that are part of two USGS programs, the Alaska Mineral Resource Assessment Program (AMRAP) and the Trans-Alaska Crustal Transect (TACT), continued to provide information about mineral wealth and geologic structures on both regional and local scales. USBM reports released in 1986 include those on predictions of remaining Alaskan precious-metal reserves based on past production; economic-feasibility studies of mineral deposits near Juneau and for offshore Alaska; assessment of platinum potential in Goodnews Bay; statewide chromite investigations; and mineral-resource assessments for southern and southeastern Alaska. In 1986, the USBM enlarged its computerized data base for mineral deposits and land status, and continued studies of new technologies to treat effluent waters from placer mines.

In response to litigation concerning the management of mining on national park lands, the National Park Service (NPS) significantly increased its minerals-management staff in Alaska during 1986. NPS activity centered on the task of developing and implementing policies and programs designed to comply with Federal regulations for environmental impacts resulting from mining activities.

The U.S. Forest Service (USFS) continued environmental-impact studies of the Greens Creek and Quartz Hill proposed mine-development plans in southeastern Alaska. In addition, the USFS is compiling mineral-resource data on Tongass $\mathrm{Na-}$ tional Forest for land-management purposes.

In 1986, the FWS conducted baseline studies, environmental analyses, and monitoring to ensure protection for fish, wildlife, and habitat during mining activities at several national wildlife refuges.

\section{Industrial Minerals}

Sand and gravel provided the second most valuable mineral production in the State of Alaska again in 1986. Nevertheless, production rates dropped by one-quarter over the 1985 rates, as oilrelated construction on the North Slope and urban construction declined in reaction to plunging oil prices.

Building-stone use increased substantially as a result of major construction projects in the Pribilof Islands, near Nome, and east of Homer.

Leasing, permitting, and mitigating the impacts of mining sand and gravel were the major Federal activities related to industrial minerals in Alaska. In 1986, the BLM issued permits for sand and gravel along the Trans-Alaska Pipeline. The FWS exchanged subsurface rights to sand and gravel on land within the Kenai National Wildlife Refuge for an easement along the Kenai River. The USFS provided sand and gravel for road and other construction activities.

\section{INTRODUCTION}

Section 1011 of ANILCA of 1980 requires that "On or before October 1, 1982, and annually thereafter, the President shall transmit to Congress all pertinent public information relating to minerals in Alaska gathered by the United States Geological Survey, Bureau of Mines, and any other Federal agency." The USGS has been delegated as the lead agency in responding to this requirement. This Circular, the sixth in a series, synthesizes information made public in 1986 and early 1987, and focuses on information about onshore areas of Alaska.

USGS and the USBM are the principal Federal agencies that generate information about mineral resources in Alaska. Their data, analyses, and reports are used by other agencies in decisionmaking on land use, access, environmental impacts, and, in some instances, claim evaluation.

In February 1987, representatives from six Federal ageneies (USGS, USBM, BLM, FWS, NPS, and USFS) and the State of Alaska met to coordinate research plans for Alaskan minerals with agency needs for minerals management. Further cooperative efforts among these agencies are expected in 1987 .

As used herein, the term "public information" includes results of Federal projects as published in Government reports and professional and trade journals; talks by representatives of Federal and State agencies and industry at symposia, conferences, and other public forums; and proceedings volumes, press releases, and newspaper articles. Cited references are listed at the end of this report; additional pertinent literature selections are listed in appendix 1. Data from 
the annual summary of industrial-mineral activity in Alaska, published by the Alaska Division of Geological and Geophysical Surveys (ADGGS), are used in parts of this report.

The report is structured around two primary categories of minerals: energy resources (oil, gas, uranium, geothermal, coal, and peat) and nonfuelmineral resources (metallic and industrial minerals).

The next several pages describe the current onshore mineral programs of land-management and other Federal agencies in Alaska. The roles of these agencies as they relate to minerals are discussed in appendix 2. The distribution of ANILCA conservation units and the locations of lands under Federal management are shown in figure 1 .

\section{MINERAL PROGRAMS}

\section{DEPARTMENT OF THE INTERIOR}

\section{U.S. Geological Survey}

As directed by Section 1010 of ANILCA, the Secretary of the Interior requires an assessment of "the oil, gas, and other mineral potential on all public lands in the State of Alaska in order to expand the data base with respect to the mineral potential of such lands." AMRAP is an example of the response of the USGS to this legislation. The goal of this program is a systematic investigation of the State's metallic-mineral resources, through four progressively more detailed levels of study. Studies at levels I and II are general and cover large areas. Studies at level III draw on many geologic disciplines to produce areal resource reports and maps at scales of $1: 250,000$ and $1: 125,000$. In all, 29 level III studies have been finished or are nearly complete. A total of 37 level IV studies were under way in 1986 , including detailed studies of specific mining districts, mineral deposits, or topics related to the genesis of mineral deposits. These studies are used to help determine the distribution and quality of national mineral and energy endowments and to aid in formulating policy affecting their use and in improving technology to minimize potential hazards or impacts. These studies also help industry locate new mineral deposits and develop concepts, models, and techniques to identify such deposits. USGS publications are frequently used by industry as a source of information about known mineral deposits in the State.

The USGS carries on its work in Alaska through several programs in addition to AMRAP. Among the programs active in 1986 were: (1) the Earthquake Hazards Reduction Program, which seeks to mitigate earthquake losses through providing data and evaluations for land-use planning, engineering, and emergency preparations; (2) the Volcano Hazards Program, which includes studies on the assessment, reduction, and prediction of volcanic hazards; (3), the Geologic Framework Program, involving both general and specialized research on the regional geology of the State; (4) studies of mineral resources on public lands; (5) the Development of Assessment Techniques Program, whose goal is improvement of the ability to identify and evaluate mineral resources; (6) the Critical and Strategic Minerals Program, for identifying the potential of these resources to meet national military and economic needs; (7) the Sedimentary Basins Program, which conducts studies of depositional, structural, diagenetic, and thermal processes to predict and evaluate water, mineral, and petroleum resources; and (8) the Geothermal Investigations Program, which focuses on studies of the nature, distribution, and energy potential of these resources nationally. TACT, a recent informal program, applies a multidisciplinary approach to study the Earth's crust along a corridor from the Pacific Ocean to the Arctic Ocean. This program is coordinated with the Trans-Alaska Lithosphere Investigation that includes earth scientists from the ADGGS, the University of Alaska, other universities, and private industry. The mineral-related aspects of many of these programs are more fully described in later sections of this report.

Economic-geologic information for mineral occurrences in the United States and worldwide is available through the USGS, Mineral Resources Data System (MRDS) computerized files. In Alaska, recently updated records focusing on metallic minerals contain 2,051 entries for forty $1: 250,000$-scale quadrangles in the south-central and southeastern areas of the State. Data in these files include mineral-deposit size, type, description, location, reserves, and pertinent literature references for known or potentially locatable mineral resources (see Leonard and Huber, 1987). Geologic information from the Alaska MRDS files can be used to complement economically oriented data from the USBM's Mineral Availability and Mineral Industry Location Systems computerized files, discussed in the next section. Further MRDS information can be obtained from Donald F. Huber, Central and Western Regional Representative, U.S. Geological Survey, MS 984, 345 Middlefield Road, Menlo Park, CA 94025.

\section{U.S. Bureau of Mines}

The Alaskan Field Operations Center (AFOC) of the USBM is currently active in the five programs listed below; further information on the scope and nature of these programs can be found in appendix 2.

(1) Mineral land assessment--The USBM's major emphasis in Alaska is to develop area- and commodity-oriented mineral assessments. A major part of this program focuses on evaluations of mining districts in Alaska, with assessments of the type, quantity, distribution, reserve estimation, and beneficiation potential of specific mineral deposits. The program also centers on 


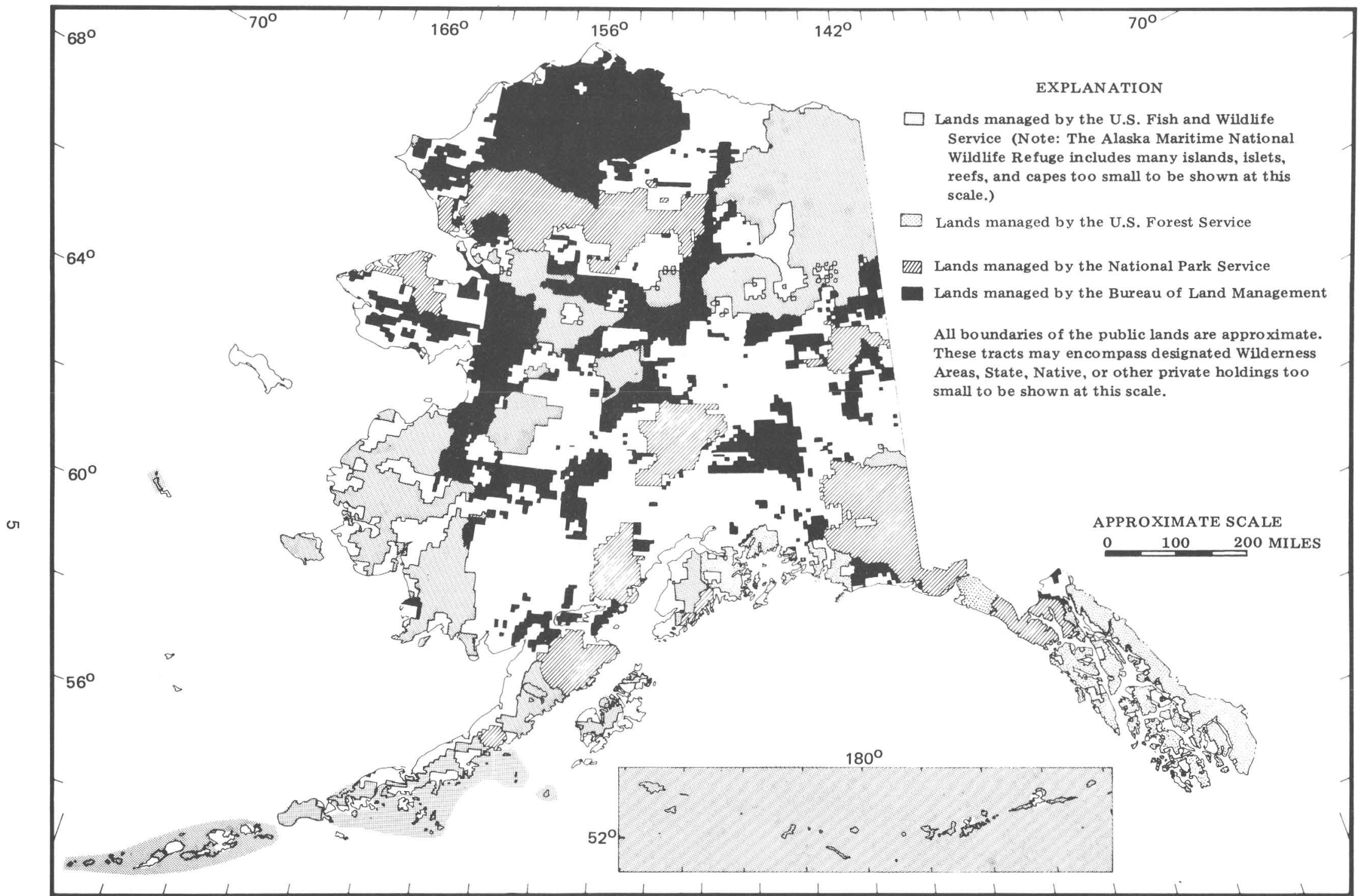

Base from maps prepared by the Bureau of Land Management in 1986.

Figure 1.--Federal land ownership in Alaska (boundaries as of February 28, 1986). Federal agencies manage approximately 70 percent of all land in the State of Alaska: Fish and Wildlife Service, 21 percent; U.S. Forest Service, 6 percent; National Park Service, 15 percent; and Bureau of Land Management, 27 percent (with a final target of 18 percent after BLM land conveyances to the State of Alaska and Alaska Native organizations). 
critical- and strategic-mineral studies throughout the State. USBM geologists and engineers locate, map, and estimate the size and grade of mineral deposits, and collect samples for metallurgic research.

(2) Minerals Availability--The two computerized components of this program are the Minerals Availability System (MAS) and the Minerals Industry Location System (MILS) data bases. The MAS contains information on reserve estimates, mineral extraction and beneficiation methodologies, environmental constraints on mining, and cost analyses for selected major mineral deposits. The MILS lists basic information on the identification and location of known mineral deposits.

(3) Minerals policy and analysis--This program compiles analyses of mineral data with respect to local and national needs. Technical, institutional, political, social, and economic parameters are used to identify mineral issues.

(4) State mineral activities-- A USBM Alaskan State Mineral Officer compiles and analyzes mineral data to report on activities and trends within Alaska's mining industry.

(5) Mineral research--In addition to mineral assessment, the USBM and university research centers are attempting to provide solutions to mineral-recovery problems. The USBM's Tuscaloosa, Ala., Research Center has been involved in field-demonstration projects in Alaska applying techniques to reduce turbidity in waters discharged in placer-mining operations.

\section{Bureau of Land Management}

The principal activities of the BLM that are related to Alaska's onshore mineral and energy resources are: (1) preparation for the scheduling of Federal oil and gas leases in onshore areas with the concurrence of the surface-management agency, (2) organization and evaluation of Federal oil and gas leases, (3) mineral and resource assessments of National Wildlife Refuges, (4) recording of mining claims and determination of the validity of claims for mineral patents, and (5) regulation of mining activities on BLM lands to protect the environment. The BLM is also responsible for enforcing environmental and technical stipulations of the Agreement and Grant of Right of Way for the Trans-Alaska Pipeline. The overall goal is to maintain a continuous supply of energy with minimal environmental impact. In addition, the BLM issues land-use authorizations and conducts mineral and material sales to support preconstruction activities for the planned naturalgas pipeline and other projects.

Administrative responsibilities for minerals require close coordination with other surfacemanagement agencies. Generally, in the case of upland or onshore leases, the BLM issues leases and integrates leasing with other land uses in cooperation with the surface-management agency. After a lease is issued, the BLM assumes jurisdiction of exploratory and development activi- ties in cooperation with the land manager to assure proper surface protections.

\section{Fish and Wildlife Service}

Mineral activities on FWS land in Alaska must conform to the agency's mission of protecting fish, wildlife, and their habitat. In Alaska, FWS activities include administration of 77 million acres of national wildlife refuge land, fish and wildlife research, law enforcement, and habitat protection through agency review of and comments on permit requests, environmentalimpact statements, and other items. The FWS has an environmental-contaminants program that includes sampling and reporting on contaminants in waters, sediments, and organisms affected by oil and gas exploration and development, placer mining, and other mineral activities.

The locations of the 16 national wildlife refuges managed by the FWS in Alaska are shown in figure 2 .

\section{National Park Service}

Minerals management programs of the NPS in Alaska include mineral examinations to determine claim validity, engineering analyses and environmental assessments (EA's) of proposed plans of operations, bonding, monitoring, and reclamation of approved operations. Guidelines for the NPS management and regulation of mining activities are discussed in appendix 2 .

\section{DEPARTMENT OF AGRICULTURE}

\section{U.S. Forest Service}

Under a memorandum of understanding with the BLM, the USFS jointly administers the general mining laws on its own lands in Alaska. An example of this joint responsibility is the patent issued to U.S. Borax and Chemical Co. for mining claims at their Quartz Hill deposit near Ketchikan. The USFS recommended issuance of this patent on the basis of favorable findings in the mineral report prepared by USFS mineral examiners.

The USFS cooperates with Department of the Interior agencies, particularly the BLM, in issuing mineral leases and assuring mitigation of surface impacts of such activities. The USFS also cooperates with the State of Alaska and the private sector in development of energy and mineral resources on inholdings. One such inholding is the Bering River coal field, under consideration for possible development by Chugach Alaska, Inc., and others in a consortium.

In Alaska, 23 million acres of land are administered by the USFS (fig. 1), whose regional office is in Juneau. Offices for Chugach National Forest are in Anchorage, Seward, and Cordova, and for Tongass National Forest in Sitka, Ketchikan, and Petersburg. 


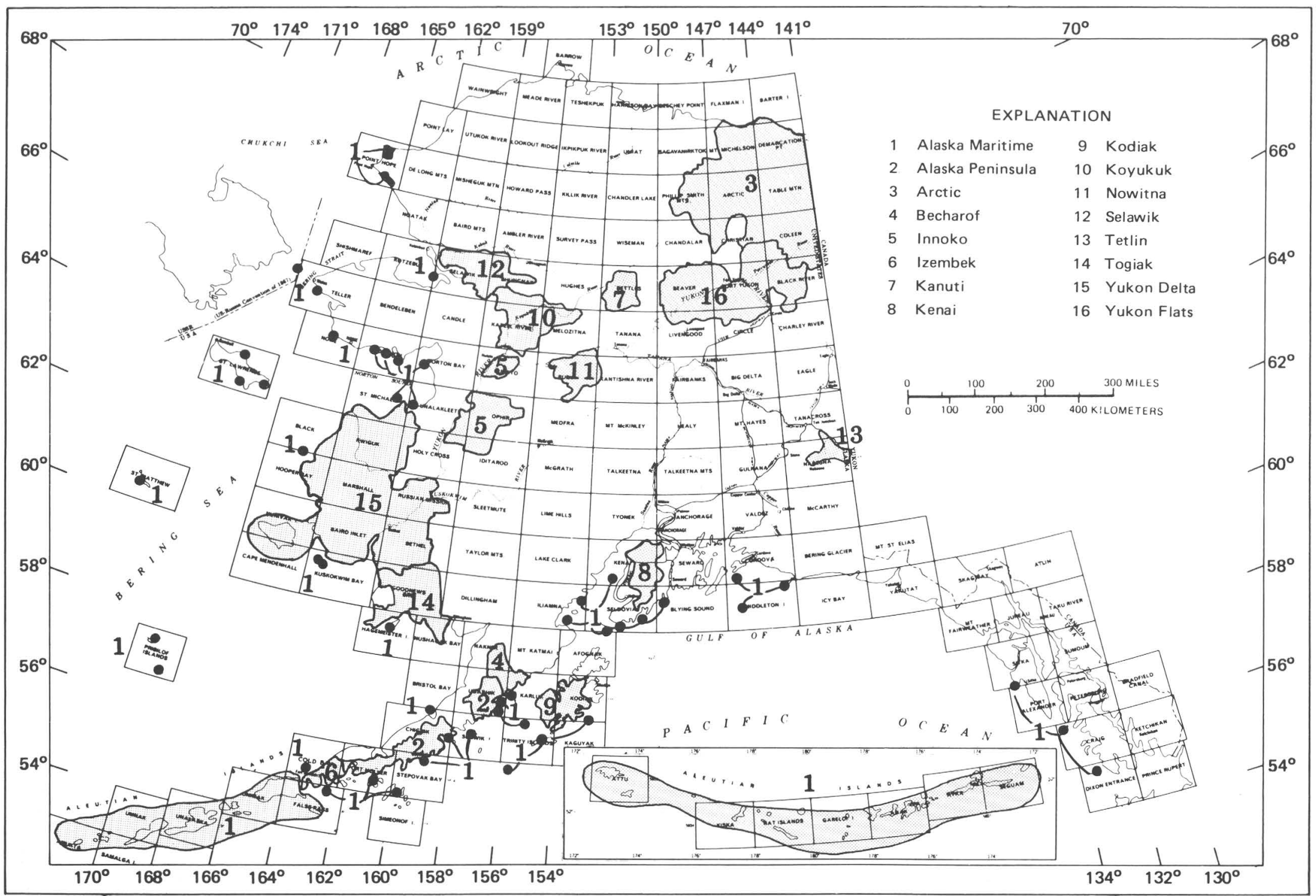

Figure 2.--National wildlife refuges in Alaska. 


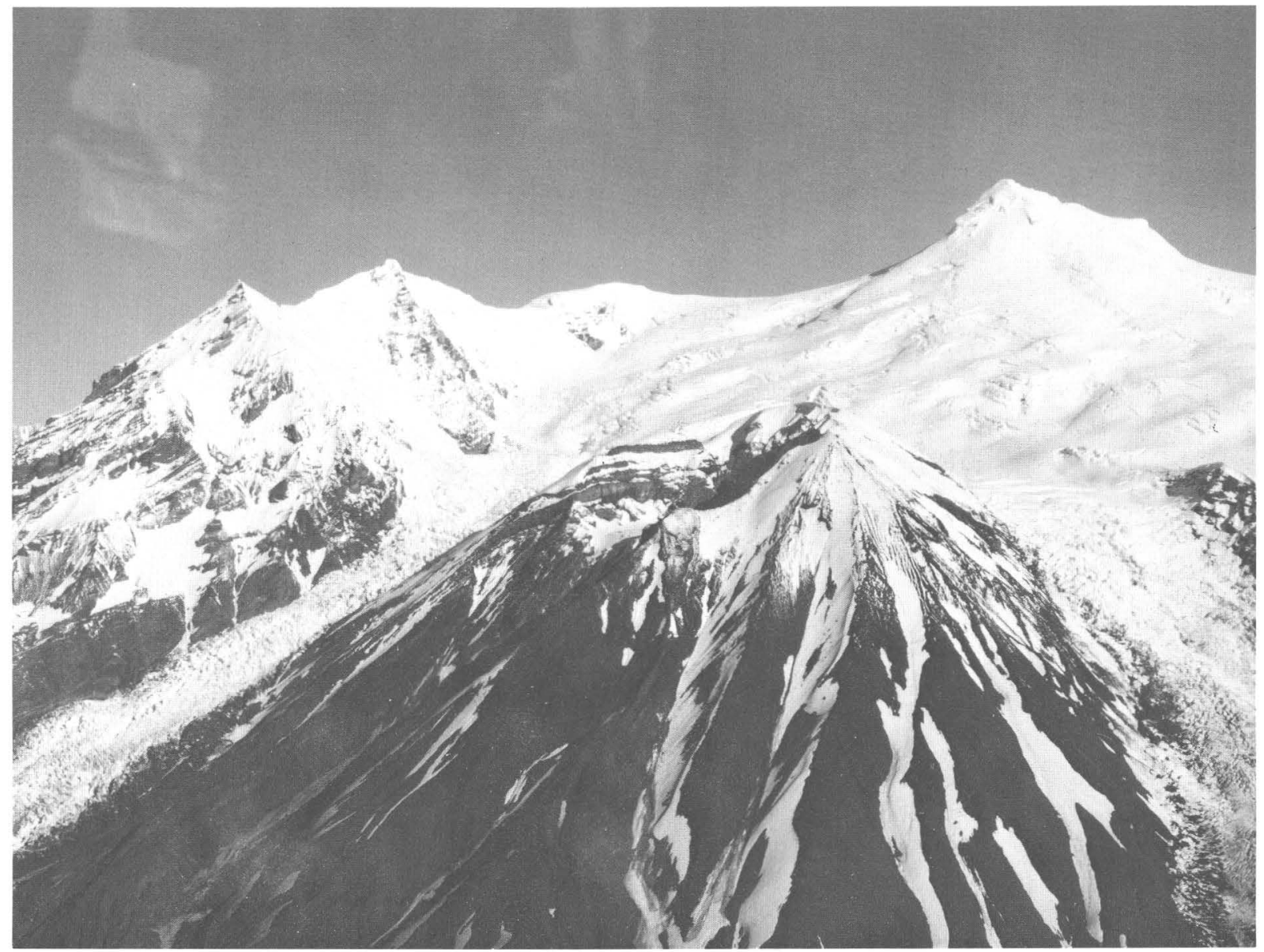

Figure 3.--Mount Spurr volcano, $70 \mathrm{mi}$ west of Anchorage, is subject of geothermal-resource research funded by the Department of Energy. Photograph by M.E. Yount.

\section{DEPARTMENT OF ENERGY}

In Alaska, the DOE is focusing its efforts on petroleum, coal, and geothermal resources. The DOE in Alaska administers current petroleum acts and Congressional mandates relating to energy, monitors grants, and oversees contracts for energy-resource studies. DOE funding helps to support USGS resource-assessment studies and research by the ADDGS and the University of Alaska.

To develop a better understanding of both conventional and unconventional petroleum resources and to provide fundamental information to accelerate use of these resources, the DOE focuses on investigating resources and technologies that continue to expand the body of essential basic seientific knowledge of conventional and heavy petroleums, shale oil, tar sands, gas hydrates, and deep-source gas. Gas hydrates, deep-source gas, and Arctic offshore energy are specific targets of DOE research in Alaska.
The DOE is working to evaluate Alaskan coal in terms of its contribution to the total resources of the Nation. Coal research currently centers on utilization methods suitable to Alaskan coals and conditions.

The DOE has established several computerized data bases, including the Arctic and Offshore Research Information System (AORIS), which is designed to provide scientific oil- and gas-related information for use by the Arctic energy community. AORIS is composed of a directory of 85 available energy-related data bases; a bibliography containing approximately 7,000 citations; and a quantitative database on sea ice, ice gouging, and subsea-permafrost characteristics.

The DOE's Geothermal Energy Program provided funds in Alaska to the University of Alaska's Geophysical Institute and the ADGGS for research about specific geothermal systems (fig. 3). Through the cooperation of Federal and State agencies, a significant information base on Alaska's geothermal resource has been developed and is now available to the public. 
The DOE's National Uranium Resource Evaluation (NURE) Program, formerly active in Alaska, has been terminated. All nonproprietary geoscience data from this program have been transferred to the USGS. Proprietary information about reserves or production are being retained by the DOE Energy Information Administration. Inspection of cores and cuttings can be arranged through T.C. Michalski, U.S. Geological Survey, MS 975, Box 25046, Denver Federal Center, Denver, CO 80225; information about sample analyses can be obtained from B.R. Burger, MS 973, at the same address.

The DOE closed its regional office in Anchorage in 1985. Requests for information about DOE Alaskan activities should be addressed to the offices listed below.

\section{CONTACTS FOR FURTHER INFORMATION}

Bureau of Land Management

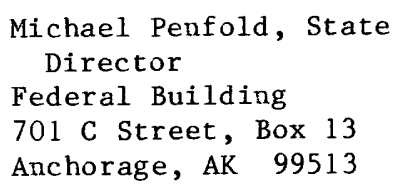

Fish and Wildlife Service

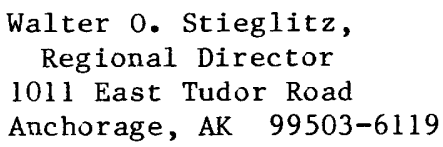

National Park Service

Boyd Evison, Regional
Director
Alaska Regional office
2525 Gambell Street
Anchorage, AK $99503-2892$

U.S. Bureau of Mines

Donald P. Blasko, Chief
Alaska Field Operations
Center
201 East Ninth Avenue,
Suite 101
Anchorage, AK 99501

U.S. Geological Survey

Donald Grybeck, Chief Branch of Alaskan Geology 4200 University Drive Anchorage, AK 99508-4667
U.S. Forest Service

Michael Barton, Regional

Forester, Alaska Region

P. 0. Box 1628

Juneau, AK 99802

Department of Energy

Hydrocarbon resources

Joseph Lagler

Morgantown Energy

Technology Center

P. O. Box 880

Collins Ferry Road

Morgantown, WV 26505

Geothermal resources

Marshall Reed

Geothermal Technology Division

U.S. Department of Energy, CE-342

Washington, DC 20585

\section{ENERGY RESOURCES}

\section{OIL AND GAS}

\section{Overview of Production and Prices}

In 1986 , as in the previous several years, oil and gas were the most valuable commodities produced in Alaska. Alaska's two oil-producing areas, the Arctic North Slope and Cook Inlet (fig. 4), supplied a total of 681.3 million bbl ( $1 \mathrm{bbl}=42$ gal) of oil, 182 billion $\mathrm{ft}^{3}$ of dry natural gas, and 1.20 billion $\mathrm{ft}^{3}$ of casinghead gas in 1986 . These values represent an increase over 1985 production of about 2.3 percent for oil and 4.3 percent for gas (Alaska Oil and Gas Conservation Commission, 1987). Production increases on the State of Alaska's North Slope leases offset the production declines from Cook Inlet. Alaskan oil production increased by about $42,000 \mathrm{bbl} / \mathrm{d}$ in 1986 , mainly as a result of production increases from the Kuparuk River field (World Oil, Feb. 1986). The rate of oil production from the entire State of Alaska at the end of 1986 amounted to $1.87 \mathrm{million} \mathrm{bbl} / \mathrm{d}$, or about 20 percent of U.S. daily production.

A decline in the world price of oil that began in late 1985 continued into 1986 (fig. 5). Between December 1985 and July 1986, the price declined from about $\$ 27 / \mathrm{bbl}$ to $\$ 9 / \mathrm{bbl}$ (Petroleum Information's Alaska Report, July 9, 1986). By the end of 


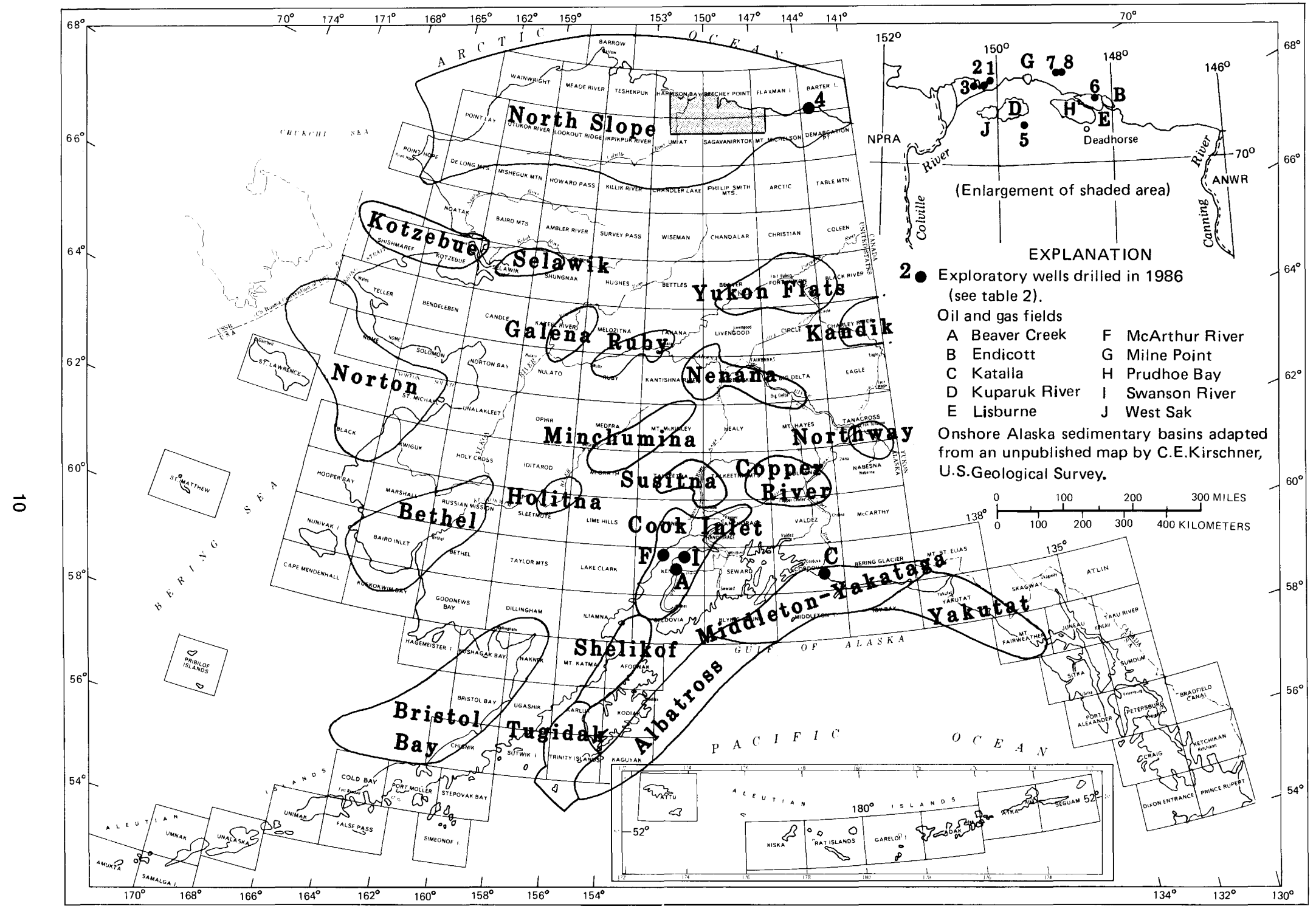

Figure 4.--Locations of exploratory wells drilled in 1986, oil and gas fields, and possible petroleum-bearing onshore sedimentary basins. 


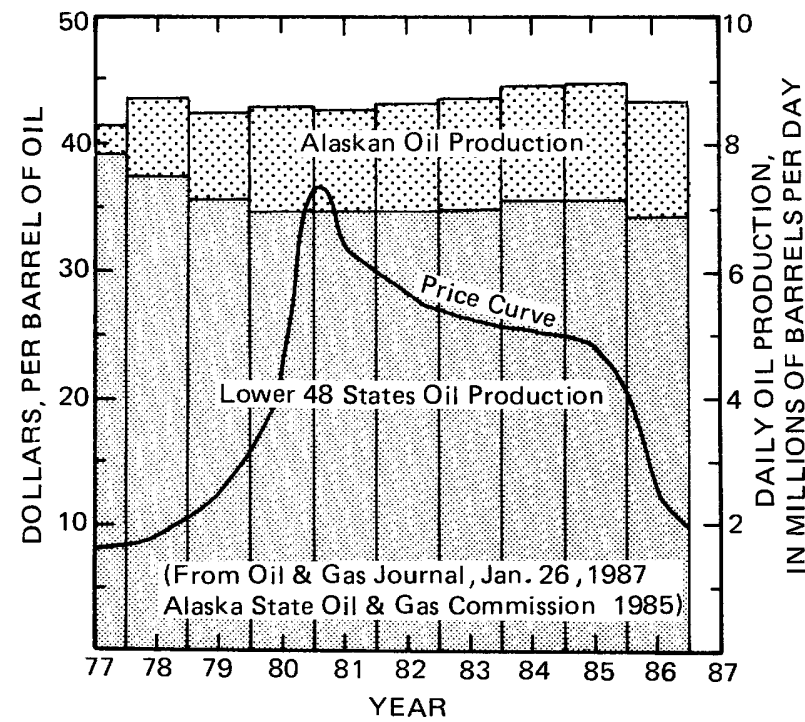

Figure 5.--Total U.S. oil production and price of oil for the years 1977 to 1986 .

1986, the price of North Slope crude oil had increased to $\$ 14.25 / \mathrm{bbl}$, delivered to the West Coast (Petroleum Information's Alaska Report, Jan. 7, 1987). The State of Alaska's economy is especially vulnerable to fluctuations in crude-oil prices because 85 percent of the State's current revenue is derived from royalties and taxes paid on State-owned oil and gas leases (Alaska Division of Geological and Geophysical Surveys, 1986). The sensitivity of exploration for, and production of, oil fields to world oil prices was reflected in the curtailment of many industry activities. For example, the Milne Point oil field, the third field to produce on the North Slope, was completely shut down by the end of the year. The major operators have announced drastically reduced capital budgets, which affect all aspects of the business and have a trickledown effect on other industries in the State. ARCO Oil and Gas, Standard Oil Co., and Chevron Corp. all had lower net incomes for 1986, attributed mainly to the falling crude-oil prices.

\section{Development and Technology}

Despite the depressed condition of the oil industry, development of the present fields is proceeding on or ahead of schedule. Contributing to the ongoing development of the North Slope, the 1986 sealift was the largest of its kind since 1975 and included 27 barges shared by ARCO Alaska and Standard Alaska Production. ARCO's share included modules for three major projects: a new miscible-gas-injection project for the Prudhoe Bay field, a third production facility for the Kuparuk River field, and the first major production facility for the Lisburne field. Standard
Alaska's share consisted of production modules for the Endicott field development. Meanwhile, Marathon Oil Co. began building the largest drilling and production platform in Cook Inlet. Platform Steelhead, located in the McArthur River field (the largest of the four fields in Cook Inlet), is capable of supporting 48 wells, which will further develop the estimated 316 billion $\mathrm{ft}^{3}$ of gas reserves and 5 million bbl of oil reserves (Pacific Oil World, Jan. 1987).

New technologies were tested on the North Slope during 1986. Standard Alaska Production drilled three horizontal development wells in the Prudhoe Bay field. The advantage of a horizontal well in comparison with a conventional well is that more area in the productive zone is exposed to the well bore, thereby allowing more oil to be produced (Oil and Gas Journal, Feb. 16, 1986). Horizontally drilled wells also have the potential to produce from areas of a reservoir that would not be practical to produce by using conventional wells, such as a very thin but laterally extensive portion of a reservoir.

Another new technology tested in 1986 was Amoco Production Co.'s ice island in the Beaufort Sea, the first commercial island built entirely out of spray ice. This low-cost alternative to costly gravel islands involves spraying seawater into the air that freezes into ice granules, collects on the sea floor, and builds up layers of ice that eventually form an island (Petroleum Information's Alaska Report, Sept. 25, 1985). Since Amoco's test was successful, future construction of manmade islands in shallow Arctic marine basins will probably utilize this economical, low-impact method.

\section{State Activity and Lease Sales}

During 1986, State agencies conducted three onshore competitive oil and gas lease sales, monitored and supervised lease development, collected rent on leases and royalties on prodution, and conducted numerous geologic and geophysical studies relating to oil and gas resource evaluation and land classification. In 1986, the Alaska Department of Natural Resources published Information Circular 31, "Oil-and-Gas Resources of Alaska," which presents an overview of the history of exploration and development, current prospects, resource estimates, and the State's leasing program.

At the competitive lease sales, a total of $\$ 3.9$ million was offered in high bids to acquire about 704,000 acres for future exploration. At least 10 oil companies and several independent investors participated in 1 or more of the 3 sales. Information about the lease sales is summarized in table 1, and the locations of the lease areas are shown in figure 6 . The terms of the leases, which in 1986 were all on State lands, can be obtained from the Lease Administration Office, Alaska Department of Natural Resources, 555 Cordova 


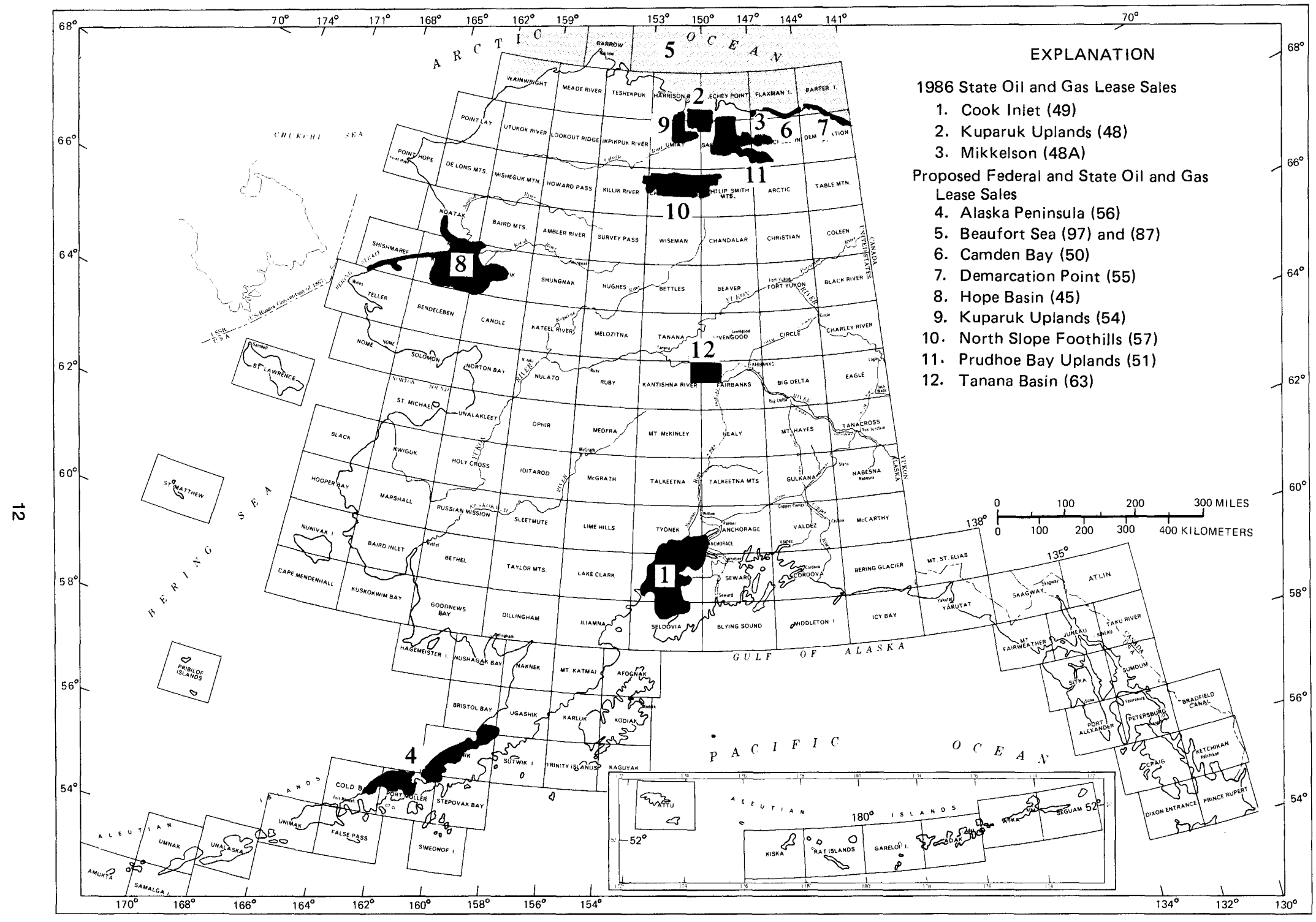

Figure 6.--Areas of oil and gas lease sales. 
Table 1. -- Onshore oil and gas lease sales, 1986

[Areas shown in figure 6. All sales were conducted by the State of Alaska; value of high bids in millions of dollars. Data from Alaska Division of oil and Gas ]

\begin{tabular}{llcccr}
\hline Area & Sale & Sale date & $\begin{array}{c}\text { Acres offered } \\
(\mathrm{x} 1,000)\end{array}$ & $\begin{array}{c}\text { Acres bid } \\
\text { on }(\mathrm{x} \mathrm{1,000)}\end{array}$ & $\begin{array}{c}\text { Total high } \\
\text { bids }\end{array}$ \\
\hline & & & & & \\
1 & 49 & $6 / 24$ & 1,189 & 395 & .95 \\
3 & 48 & $2 / 25$ & 526 & 267 & 2.44 \\
3 & $48 \mathrm{~A}$ & $2 / 25$ & 42 & 42 & .51 \\
\hline
\end{tabular}

Table 2.--Exploratory test wells on State and Native lands, 1986

[Data from Alaska Division of Oil and Gas; see figure 4 for 1ocations. P\&A, plugged and abandoned; S, suspended]

\begin{tabular}{|c|c|c|c|c|c|c|}
\hline We11 & Company & Wel1 name & $\begin{array}{c}\text { Location } \\
\text { (Umiat meridian) }\end{array}$ & $\begin{array}{c}\text { Total } \\
\text { depth ( } f t)\end{array}$ & $\begin{array}{c}\text { Date } \\
\text { completed } \\
\end{array}$ & Remarks \\
\hline 1 & Texaco & Colville Delta 2 & Sec. 23, T. 13 N., R. 7 E. & 6,800 & $3 / 16$ & $P \& A$ \\
\hline 2 & Texaco & Colville Delta 3 & Sec. 33, T. 13 N., R. 7 E. & 6,800 & $3 / 31$ & $P \& A$ \\
\hline 3 & Amerada Hess & Colville Delta 25-1 & Sec. 25, T. 13 N., R. 6 E. & 6,871 & $3 / 04$ & $P \& A$ \\
\hline 4 & Chevron & $\mathrm{KIC}^{1}$ Well 1 & Sec. 1, T. 8 N., R. 36 E. & 15,193 & $4 / 24$ & $P \& A$ \\
\hline 5 & ARCO & $\begin{array}{c}\text { Kuparuk River } \\
\text { Unit WT-1 }\end{array}$ & Sec. 22, T. 10 N., R. 10 E. & 4,015 & $3 / 07$ & $P \& A$ \\
\hline 6 & Standard Prod. & Niakuk 6 & Sec. 25, T. 12 N., R. 15 E. & 13,107 & $3 / 25$ & $S$ \\
\hline 7 & Amerada Hess & Northstar $1^{2}$ & Sec. 32 , T. 14 N., R. 13 E. & 11,820 & $1 / 15$ & $\mathrm{~S}$ \\
\hline 8 & Amerada Hess & Northstar 2 & Sec. 32 , T. 14 N., R. 13 E. & 11,921 & $4 / 06$ & $P \& A$ \\
\hline
\end{tabular}

${ }_{2}^{1}$ KIC=Kaktovik Inupiat Corp.

2 oil discovery

Street, Anchorage, AK 99501. For further information about State petroleum-related activities, the reader should contact the Alaska Division of Oil and Gas, 3601 C Street, Anchorage, AK 99503; or obtain Information Circular 31 from the Alaska Department of Natural Resources, Division of Geological and Geophysical Surveys.

\section{Industry Activity}

Industry activity for onshore Alaska in 1986 included further delineation of a new oil field and startup of oil production from another field, both of which are located on the North Slope, as well as geophysical and geologic surveys and drilling of 8 exploratory wells (fig. 4; table 2) and about 135 development wells. Development drilling was concentrated primarily on the North Slope in four producing and several developing fields. The eight exploratory wells are all located on the North Slope. Little information has been released to the public, but some is being made available through private subscription services, such as the weekly Alaska Report (published by Petroleum
Information). Oil discovered in the Amerada Hess Northstar No. 1 well is believed to be an extension of the Colville Delta reservoir, first discovered in 1985 by Texaco and its partners. Chevron USA, Inc., Standard Oil Co., and BP Alaska Exploration Co. drilled the first exploratory well on Native lands in the ANWR. There has been great interest in waiting for results of the KIC (Kaktovik Inupiat Corp.) No. 1 well because the ANWR is considered to contain the most promising accumulation of hydrocarbons remaining on the North Slope.

The Prudhoe Bay field (fig. 4), the world's 19 th largest producer (Tiratsoo, 1984) and the largest field in the United States, produces 1.53 million bbl/d of oil. A seawater-treatment plant installed in 1984 injects about $1.4 \mathrm{million} \mathrm{bbl} / \mathrm{d}$ of water into the producing reservoir to increase the amount of oil recovered (Petroleum Information's Alaska Report, Feb., 1987). In September 1986, the Trans-Alaska Pipeline transported its 5billionth barrel from the North Slope to the deepwater terminal at Valdez, in the Gulf of Alaska. This record represented the estimated halfway point for production from the Prudhoe Bay field, 
which has accounted for about 17 percent of the Nation's output since 1977 (Pacific Oil World, Jan. 1987).

The second largest oil field in the United States, the Kuparuk River field, produced about 94 million bbl of oil in 1986, or an average of about $258,000 \mathrm{bbl} / \mathrm{d}$. Beginning in December, a new production facility was brought on line to boost daily output by about 16 percent to 300,000 $\mathrm{bbl} / \mathrm{d}$. The Kuparuk field produced its 200millionth barrel after 4 years of operation (Alaska State Oil and Gas Conservation Commission, 1987).

The Milne Point field, the third field to produce oil on the North Slope, has suspended production only 1 year after beginning operation. Conoco, Inc., and partners (Champlin Petroleum Co., Cities Service Oil and Gas Co., Chevron USA, Inc., and Reading and Bates Petroleum Co.) cited several factors for the shutdown, including the depressed price of crude oil, and equipment problems that cut daily output by half (from 20,000 to $10,000 \mathrm{bbl} / \mathrm{d})$. The Milne Point field contains estimated recoverable reserves of 100 million bbl, with plans for the field to produce $30,000 \mathrm{bbl} / \mathrm{d}$. Conoco is keeping the facility operational, should there be a sudden increase in the price of oil (Petroleum Information's Alaska Report, Dec. 10, 1986).

On December 15, 1986, the Lisburne field became the fourth oil field to begin production on the North Slope. ARCO Alaska, Inc., and its partners Exxon Co. USA and Standard Alaska Production Co. plan to produce 40,000 to 50,000 $\mathrm{bbl} / \mathrm{d}$ from the field, which underlies the northeastern part of the Prudhoe Bay field. The Lisburne production facility has a capacity to produce $100,000 \mathrm{bbl} / \mathrm{d}$ from the $300 \mathrm{million} \mathrm{bbl}$ of estimated recoverable reserves (Petroleum Information's Alaska Report, Dec. 17, 1986).

The Endicott field, with reserves at 350 million bbl of oil and 800 billion $\mathrm{ft}^{3}$ of gas, is scheduled to begin production in late 1987. Standard Alaska Production Co. is using two island bases for the development of this field. Oil from the Endicott field will be transported by pipeline to the Trans-Alaska Pipeline's Pump Station No. 1 at Prudhoe Bay (Pacific Oil World, Jan. 1987).

ARCO Alaska, Inc., has concluded a 2-year pilot project to determine the feasibility of producing the estimated 20-billion-bbl heavy-oil accumulation at the West Sak field on the North Slope. The reservoir covers about $250 \mathrm{mi}^{2}$ and is located at depths between 3,000 and $4,000 \mathrm{ft}$. The project involved injecting hot water into the reservoir in hopes of reducing the viscosity of the oil, thereby allowing the oil to flow more easily through the reservoir (Anchorage Daily News, Jan. 22, 1987).

The Katalla oil field located in the Gulf of Alaska, abandoned since the 1930 's, has been reactivated. Alaska Crude Corp. (ACC) resumed drilling the KS No. 1 well in 1986. However, by
November, ACC had suspended operations at the Katalla River location, where the company had planned to drill 10 shallow production wells to recover an estimated 3 million bbl of oil (Petroleum Information's Alaska Report, Dec. 31, 1985).

\section{Activity by Federal Agencies}

\section{U.S. Geological Survey}

The North Slope continues to be the focus of most USGS studies related to onshore oil and gas resources. Many of these studies are part of the Evolution of Sedimentary Basins program or the Gas Hydrate program. South of the Brooks Range, basin studies are supported by the AMRAP. The paragraphs below summarize recent activities; selected pertinent reports are listed with the USGS and DOE publications in appendix 1 .

Many of the numerous talks and posters concerning the geologic aspects of Alaskan oil and gas resources that were presented at the regional meeting of the American Association of Petroleum Geologists (AAPG) and the Society of Economic Paleontologists and Mineralogists (SEPM) held in Anchorage in 1985 are nearing publication. More than 100 papers and abstracts are scheduled for mid-1987 publication by the SEPM'S Pacific Section and the Alaska Geological Society (Tailleur and Weimer, 1987). The National Convention of the AAPG and SEPM, to be held in Los Angeles in June 1987, will have several talks and posters reviewing studies in Alaska by the USGS (for list of abstracts, see AAPG Bulletin, v. 71 , no. 5,1987$)$.

\section{National Petroleum Reserve in Alaska}

The operational phase of the Federal petroleum-exploration program in the NPRA was completed in 1981. A nontechnical report (Gryc, 1985) describes this program. Meanwhile, more than 30 technical papers by USGS scientists will be published as a future USGS Professional Paper. Topics included are stratigraphy, sedimentation, seismic stratigraphy, petrography, paleontology, biostratigraphy, petroleum source-rock geochemistry, structural geology, direct hydrocarbon detection by aeromagnetic and helium methods, assessment results, and exploration history. Most data from the 1974-81 exploration program, as well as numerous pertinent contractor reports, are available to the public through the National Geophysical and Solar-Terrestrial Data Center, Boulder, CO 80303. Their catalog itemizes information about 38 wells, 14,770 line-miles of seismic-reflection surveys, 52,000 gravity measurements, and numerous reports about geology, geophysics, the environment, construction, and logisties.

\section{Gas Hydrates}

The North Slope natural-gas-hydrate-evalua- 
tion project, funded by the DOE, continued to be very active through 1986. Study of the physical properties controlling inplace natural-gas-hydrate stability dominated the research efforts. Topics of talks and publications during 1986 included: an evaluation of subsurface geothermal gradients and their effect on gas-hydrate stability (Collett and others, 1986b), determination of the regional effect of freezing-point depression at the base of ice-bearing permafrost (Collett and others, 1986a), and development of a regional stratigraphic-correlation framework (Molenaar and others, 1986a, b). Geologic and geochemical samples collected from an ARCO Alaska Co. production well in the Kuparuk River field are being studied to determine the compositions of natural gases in the nearsurface sediments (at depths of $0-1,000 \mathrm{~m}$ ) of the North Slope and to characterize the potential gashydrate reservoirs.

\section{Petroleum Potential of the Eastern Brooks Range}

In another DOE-funded study, the USGS and university scientists conducted geologic studies in the eastern Brooks Range and Charley River-Eagle areas (area 9, fig. 7). The goal of these studies is to project the known structural and stratigraphic relations into the Yukon Flats sedimentary basin and to evaluate the potential of that area for generating and trapping deep gas resources. This work is part of a larger effort to evaluate the potential for the occurrence of deeply buried petroleum resources along ancient convergent continental margins where obductive processes have been dominant. Field mapping and paleontologic and geochemical studies have shown new age and structural relations in these geologically complex areas, in which several accreted terranes are now recognized.

\section{Interior Basins of Alaska}

During 1986, USGS scientists continued their work summarizing the geology and evaluating the petroleum potential of the interior sedimentary basins of Alaska (those south of the North Slope and generally north of Cook Inlet; see fig. 4). During a 5-week helicopter-supported field program, the facies relations, sedimentology, and biostratigraphy of the Tertiary fluvial and lacustrine deposits in the Nenana Basin were studied. Using Rock-Eval pyrolysis, vitrinite reflectance, and kerogen tests, the petroleum-source potential of the coals and mudrocks associated with the Tertiary deposits was determined. Two articles in USGS Circular 998 show the results of the Nenana Basin studies (Stanley, 1987a, b) and a poster session presented at the 1987 National American Association of Petroleum Geologists Convention summarizes the reconnaissance study of the Cantwell Formation (Stanley, 1987c). Future studies include interpretation of the stratigraphy and petroleum geology of the two wells drilled in the basin. During an additional 3-week reconnaissance field program, the petroleum potential of the Matanuska Valley north of Anchorage, the Copper River basin, and the Yukon-Kandik Basin was assessed. Two abstracts and a poster session presented at the 1987 National AAPG Convention in Los Angeles review the findings of this reconnaissance work (Cook and others, 1987; Magoon and others, 1987).

\section{Central Arctic Management Area}

The USGS is working in cooperation with BL.M geologists and geophysicists on an oil and gas assessment of the Central Arctic Management Area (CAMA), lands between the NPRA and the ANWR north of lat $68^{\circ}$ N. (fig. 7). The Brooks Range overthrust belt, along the south boundary of the CAMA, is a geologically complex area with structures similar to those of oil-bearing areas in the Rocky Mountains. Fieldwork in the 1:250,000scale Killik River and Chandler Lake quadrangles has been completed, and an evaluation of the petroleum potential is underway. Objectives of this study include: (1) the type and abundance of potential hydrocarbon traps, (2) the extent and distribution of potential reservoir rocks, and (3) the potential for hydrocarbon-source rocks by organic geochemical analyses.

\section{Additional Studies}

Results of several USGS studies have recently been released. USGS Bulletin 1596 (Magoon, 1986) is a collection of a dozen papers on geologic studies related to the Continental Offshore Stratigraphic Test (COST) well drilled in Lower Cook Inlet in 1977. In early 1986, the USGS presented its second annual McKelvey Forum on Energy Resources in Denver, Colo. Four talks and posters dealing with Alaskan petroleum geology and energy resources, most on the North Slope, were presented. Abstracts of these were published in USGS Circular 974 (Carter, 1986).

\section{Bureau of Land Management}

In establishing and implementing an oil and gas leasing program as required by Section 1008 of ANILCA, the BLM has made land available for noncompetitive oil and gas leasing and for mineral entry under the Mining Law of 1872 in three areas south of lat $68^{\circ} \mathrm{N}$. The Minchumina area was opened in 1981, the Denali-Tiekel area in 1982, and the Seward Peninsula in 1983. As of December 10,1986 , the BLM had issued approximately 373 leases on 91,951 acres in the Minchumina area, 6,018 leases on $1,119,388$ acres in the Denali-Tiekel area, and 1,896 leases on $1,067,706$ acres in the Seward Peninsula. A total of 291,285 acres was leased in these areas during 1986. The locations of the general lease areas are shown in figure 7 . 


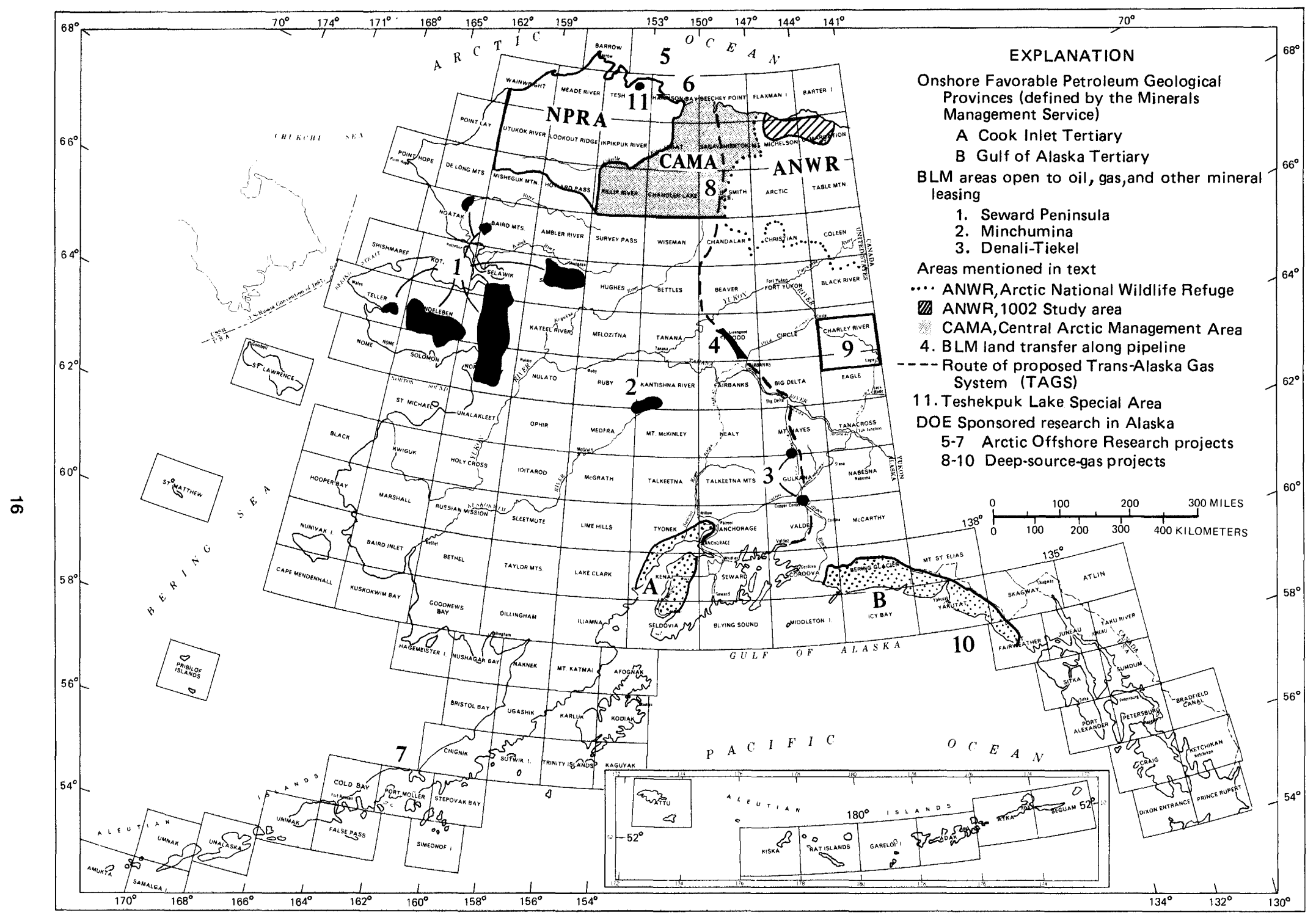

Figure 7.--Onshore Favorable Petroleum Geological Provinces, land units referred to in text, and locations of Department of Energy-funded research during 1986. 
The National Wildlife Federation v. Burford et al. lawsuit, concerning land withdrawals and classifications, specifically affects areas of the Seward Peninsula opened to oil and gas leasing and the mining laws under the authority of Section 204(a) of the Federal Land Policy and Management Act, by Public Orders 6477 and 6559 of October 5, 1983, and August 9, 1984, respectively. An injunetion effective February 14, 1986: (1) enjoins the Department of the Interior from revoking withdrawal or termination classifications in existence as of January 1, 1981; (2) enjoins the Department of the Interior from taking actions inconsistent with specific terms of the above withdrawals or classifications; (3) suspends all revocations of withdrawals and terminations of classifications completed after January 1,1981 ; (4) allows the Department of the Interior to accept filings required by law; and (5) exempts Alaska from the order where lands affected are for Native or State conveyances. Essentially, for the Seward Peninsula area, any pending offers on oil and gas leases will be suspended, and no new of fers will be considered. Mining Plans of Operations may not be approved if the lands were not open to location on January 1, 1981, and the lands remain closed to the full operation of the mining laws. However, many areas were open to the location of metalliferous minerals under the terms of the withdrawals in effect before January 1, 1981 .

A fifth lease sale in the NPRA (fig. 7) was postponed again in 1986, owing to low demand for NPRA leases and falling world crude-oil prices. A demand and market analysis will be completed in 1987 that should shape the leasing schedule for the near future. Since leasing began in 1982,56 leases covering approximately $1,350,000$ acres have been issued in the NPRA; 13 leases were relinquished or terminated in 1986 .

There were no new exploratory wells drilled on BLM-administered land during 1986.

By June 1987, the BLM provided the FWS with oil and gas resource assessments for 4 national wildlife refuges; Kenai, Becharof, Alaska Peninsula, and Yukon Flats (fig. 2). The FWS will use these assessments to help determine whether oil and gas leasing and development is compatible with the intent of these refuges.

The BLM is transferring lands in the "utility corridor" along the Trans-Alaska Pipeline between the Yukon River and Washington Creek (fig. 7) to the State of Alaska. The BLM began preparing a resource-management plan in 1986 for this corridor and adjacent BLM-administered lands north of the Yukon River. Included in this planning effort is a study of oil and gas resources, wilderness characteristics, and wildlife resources in the CAMA, as required by Section 1001 of ANILCA. This study, to be completed by the BLM no later than December 1988 , will be the basis for recommendations concerning future use and management of BLM land in the central North Slope area. BLM geoscientists are working in conjunction with USGS geologists to assess the petroleum potential of the CAMA.

The Annual Report of the BLM's Branch of Pipeline Monitoring is available through its Public Affairs Office in the Federal Building in Anchorage. This branch, part of the Division of Mineral Resources, assures that the terms and conditions of the Alyeska Pipeline Service Co.'s pipeline right-of-way are met.

The BLM's involvement with the Northwest Alaska Pipeline Co.'s proposed Alaska Natural Gas Transport System (ANGTS) remains at a low level because the project has been delayed. The Yukon Pacific Corp. submitted a modification to its right-of-way application to the BLM for its proposed Trans-Alaska Gas System (TAGS, fig. 7) from Prudhoe Bay to tidewater. The liquefiednatural-gas facility and port is now planned for Anderson Bay in the port of Valdez. The viability of both pipeline projects is linked to worldwide demand for and price of natural gas.

\section{Fish and Wildlife Service}

The primary efforts of the FWS in Alaska are to protect and conserve fish and wildlife and their habitats, and to administer 16 national wildlife refuges (fig. 2). The FWS also cooperates with other Federal and State agencies in similar efforts on behalf of wildlife throughout Alaska. Any oilor gas-related activities in refuges are subject to FWS restrictions and protective stipulations.

\section{Kenai National Wildlife Refuge}

The Kenai National Wildlife Refuge is the only refuge in Alaska from which oil and gas have been produced. In 1986,30 to 35 wells continued crude-oil production from the Swanson River, Alaska's first commercial field; production was down to approximately $5,500 \mathrm{bbl} / \mathrm{d}$. A workover rig was active in the field, correcting problems at several of the wells. Maximum production of about $50,000 \mathrm{MCF} / \mathrm{d}$ from 4 gas wells and about $450 \mathrm{bbl} / \mathrm{d}$ from 2 oil wells is being produced at the Beaver Creek field.

In 1985 , an agreement was reached between Chevron USA, Inc., and the U.S. Environmental Protection Ageney for the cleanup of polychlorinated-biphenyl (PCB)-contaminated materials inadvertently used in oil-development activities for dust control on some Kenai National Wildlife Refuge parking areas and roads. That agreement and the established cleanup levels have been accepted in a memorandum of understanding with ARCO Alaska, Inc., the unit operator, as of October 1,1986 . Contaminated roads have been blocked, and highly contaminated areas have been tarped and secured in response to the agreement. The change in unit operator necessitated a rebidding for cleanup of the PCB soil contamination. Mitigation maps were developed from an analysis of more than 1,000 soil samples. A contract to the successful bidder for cleanup was awarded in April 1987. 
Activities under Section 1008 of ANILCA

Section 1008 of ANILCA provides for oil and gas studies on refuges in Alaska to provide information for use in future land-management decisions. In 1986, special use permits were issued for surface geologic work in the Alaska Maritime and Yukon Flats National Wildlife Refuges. Chevron USA, Inc., obtained a special use permit for a gravity study in the Kenai National Wildlife Refuge. Special use permits include numerous stipulations for ensuring that permitted activities are environmentally sound and compatible with refuge purposes, and are designed for the specific locale and activities of the proposal. Bonds of $\$ 10,000$ must be posted before any company can undertake such work in Alaska refuges. Copies of data resulting from such exploration must be submitted to the FWS; they remain confidential in storage with the BLM.

Section 1008 of ANILCA also calls for establishing a program for oil and gas leasing on Federal lands south of lat $68^{\circ} \mathrm{N}$., pursuant to the Mineral Leasing Act of 1920 as amended. This program does not apply to those refuge lands where the Secretary of the Interior determines, after consideration of the national interest, that oil and gas exploration or development would be incompatible with the purposes of the refuge. Section $304(\mathrm{~g})$ of ANILCA cites a comprehensive conservation planning process as the means for identifying parts of refuges where leasing or related activities may be compatible. A final plan was issued for the Togiak National Wildlife Refuge in 1986 (U.S. Fish and Wildlife Service, 1986e). Draft plans were released for the Kanuti, Koyukuk, Nowitna, and Selawik National Wildlife Refuges in 1986 (U.S. Fish and Wildlife Service, 1986a, b, c, d); final versions for those refuges, as well as for the Yukon Flats, Tetlin, and Kodiak National Wildlife Refuges, are scheduled for 1987. Draft and final plans for the Yukon Delta and Innoko National Wildlife Refuges will be prepared in 1987. Draft plans prepared for the Alaska Maritime and Arctic National Wildlife Refuges in 1987 will be finalized in 1988 (see fig. 2 for NWR locations).

National-interest determinations involved in the Section 1008 process are being requested from the DOE. In 1986, the DOE determined it to be in the national interest to allow leasing anywhere within the Kodiak National Wildlife Refuge. The BLM is providing the FWS with information on the oil and gas potential of refuges for use in finalizing leasing policy on the comprehensive conservation plans. Preliminary information has been provided for the Alaska Peninsula, Becharof, and Yukon Flats National Wildlife Refuges.

Refuge lands leased by the BLM will be competitively leased if the land is in a Favorable Petroleum Geologic Province (as identified by the Minerals Management Service) (fig. 7), or noncompetitively leased if not within such a province. All leasing, exploration, and production would be subject to permits and stipulations designed to protect fish, wildlife, and subsistence activities.

\section{Mineral-Activity-Impact Assessment}

FWS mineral-related activity includes making recommendations for mitigating adverse impacts on fish, wildlife, and their habitats. To this end, the FWS reviews U.S. Army Corps of Engineers permit applications under Section 404 of the Clean Water Act of 1977; these applications may involve public or private lands. This review includes making recommendations for minimizing habitat losses in all proposals for new or modified roads, pads, well sitings, and operations.

As a result of Section 404 permit negotiations concerning the onshore part of the Lisburne project (fig. 4), a 1984 letter of agreement from ARCO Alaska, Inc., stated their intent to mitigate for habitat losses from gravel fill in consultation with the FWS. Negotiations under this agreement to ensure that impacts are fully mitigated continued in 1986. The process of quantifying losses and determining exactly how to minimize them has been difficult. Compensation of losses through acquisition and management of habitat outside the project area may be necessary. However, ARCO Alaska, Inc., has not yet agreed to compensate for habitat losses. Discussions have begun on controlling gull and fox populations that have become abnormally high in North Slope oil-development areas, resulting in increased predation on eggs and young birds. However, the FWS does not support predation control as an appropriate mitigation for habitat losses.

Field activities in northern Alaska included continuing water-quality studies of North Slope lakes and tundra ponds both within and away from development areas between the Colville and Canning Rivers. Contaminant studies in the Prudhoe Bay/Kuparuk oil fields included collecting sedgegrass, chironomids, and Daphnia for analysis of metals uptake; sedgegrass samples were analyzed for the uptake of hydrocarbons. Water and sediment samples were also collected.

The FWS helps monitor studies regarding impacts to birds and fish from the offshore production well, causeway, and related facilities for the Endicott project. The studies began in 1985 and are to continue throughout the lifetime of the project. The FSW is a member of the interagency technical-review committee involved with this project. As part of the mitigation required for the Endicott project on the North Slope, the FWS has been jointly managing, with Standard Alaska Production Co., a study of Arctophila (Arctic pendant grass) to determine the feasibility of revegetating disturbed wetlands.

The Habitat Management Plan for the Teshekpuk Lake Special Area (fig. 7), in the northeastern part of the NPRA, was developed in 1986 by the BLM in cooperation with the FWS and the Alaska Department of Fish and Game, in accor- 
dance with a 1985 memorandum of agreement. One of the most productive and diverse wetland ecosystems in Arctic Alaska, this area may be made available for leasing, although it has a low oil and gas potential, given current economies and logistics of development. A final decision on the plan was postponed, pending results of further studies on black brant use of the area.

The FWS commented on several proposed State oil and gas lease sales (fig. 6) during 1986: 45 (Hope Basin), 49 (Cook Inlet), 50 (Camden Bay), 51 (Prudhoe Bay Uplands), 54 (Kuparuk Uplands), 55 (Demarcation Bay), 56 (Alaska Peninsula), 57 (North Slope Foothills), and 63 (Tanana Basin), as well as the proposed 5-year plan for State oil and gas lease sales. Additionally, the FWS commented on the Minerals Management Service draft environmental-impact statement for the Federal Beaufort Sea Lease Sale 97, and two plans of operation for the previous Beaufort Sea Lease Sale 87. The FWS's Fish and Wildlife Enhancement field office in Fairbanks continued permit review and consultation activities for infill projects, primarily secondary and tertiary recovery, at the Prudhoe Bay oil field and for expansion of the Kuparuk oil field.

A report on the 1985 FWS workshop on the potential impacts to caribou and the mitigation possibilities with oil development on the coastal plain of the ANWR was prepared by Elison and others (1986), before a similar conference sponsored by the Alaska Oil and Gas Association and the Alaska Department of Fish and Game. The second conference, in October 1986, addressed the broader issue of the impact on caribou from oil and gas development throughout the North Slope. The FWS was a conference participant.

\section{Department of Energy}

\section{Arctic Activities}

The Arctic and Offshore Research subprogram of the DOE's Advanced Process Technology program was established to enhance petroleum-energy development by examining critical natural forces (such as sea ice and subsea-permafrost formation) and their effects and to establish a data base for Arctic parameters. Much of the subprogram's efforts are directed at offshore development (Morgantown Energy Technology Center, 1987a); onshore objectives involve enhanced oil recovery and study of heavy oil, oil shale, and tar sands.

In 1986, the DOE continued developing the Arctic energy-related technology data base (AORIS), sponsoring seminars (Morgantown Energy Technology Center, 1986), coordinating interagency research, and studying the applicability of recovery techniques to Arctic petroleum occurrences.

AORIS is a computerized information service designed to assist the technological and planning community in the development of Arctic oil and gas resources. It has three principal components: a directory that lists approximately 85 data bases containing Arctic energy-related information and how to access them; a bibliographic/management information system (B/MIS) containing approximately 7,000 references and abstracts on energyrelated research; and a scientific and engineering information system containing quantitative data on sea ice, ice gouging/scouring, and subseapermafrost characteristics from the B/MIS citations. AORIS also contains much unpublished information on the Arctic.

\section{Sea-Floor-Soils Research}

To improve Arctic petroleum-development technology, the DOE sponsored sea-ice and seafloor-soils research through several institutions and agencies. At the University of Alaska, research was on ice-island generation from the Canadian lslands ice shelves and their drift paths into the Alaskan Beaufort Sea, and on determining spray-ice bond strength to of fshore structures and vessels. Several ice islands that have calved off the Canadian Ellesmere Island ice shelves during the past few years are being electronically tracked in hopes of developing a drift-simulation model. Most of these buoy-equipped ice islands are currently located off Axel Heiberg Island, about 375 miles west of Greenland, and are slowly proceeding southwest toward Alaska. Sea-sprayice bond shear strength to various structural and protective coatings has also been determined (1-4 $\mathrm{lb} / \mathrm{in}^{2}$ ). Research demonstrated that a polyethylene coating showed the most potential for rapid shedding of spray ice by gravity loading.

Through the U.S. Army's Cold Regions Research and Engineering Laboratory, in cooperation with the USGS, research is designed to determine the seasonal changes in temperature and salinity at the seabed and how those changes influence seabed freezing and the occurrences of ice-bonded permafrost. During August 1985, four instrument packages that measure temperature and salinity values at the seawater/seabed interface were deployed in Harrison and Prudhoe Bays (fig. 7). Information was collected hourly over the past year, and the instruments and data were retrieved in August 1986. The data are currently being evaluated.

Research conducted by Sandia National Laboratories, in cooperation with the Minerals Management Service, was on measuring acceleration and velocity responses of the sea-floor soils to strong earthquakes. A redesigned Seafloor Earthquake Measurement System (SEMS II) unit was deployed near Shell's Ellen-Elly platforms about 10 $\mathrm{mi}$ west of Long Beach, Calif., in $250 \mathrm{ft}$ of water. This unit successfully monitored two separate earthquakes measuring 6.0 and 5.8 on the Richter scale that occurred in southern California in July 1986. This was the first time earthquakes that occurred near an offshore drilling platform have been monitored simultaneously by sensors located 
on land (USGS seismic stations along the coast), aboard offshore platforms (Shell-installed instrumentation), and beneath the sea floor (the SEMS II monitor, buried about $5 \mathrm{ft}$ into the seabed). The DOE plans to deploy SEMS II in the Bering Sea during the late 1980's (fig. 7).

Also in cooperation with the USGS, DOE research was on the age and features of deepwater ice gouging (155- to $210-\mathrm{ft}$ water depth) in the Beaufort Sea and the factors controlling the location of the ice-ridging shear zone, where shorefast ice meets the moving icepack. These sea-floor chracteristics are important in locating sea-floor equipment and pipelines in the area of the shear zone. The ice-gouging study demonstrated strong geologic evidence that the gouges observed in water depths to $210 \mathrm{ft}$ could have occurred during the past few hundred years. The ice-ridging shear zone occurs at essentially the same position (in about $60 \mathrm{ft}$ of water) year after year, generally associated with a break in slope. The bulldozing action of the ice and the currents shape and maintain these shoals.

Petroleum Research

A primary petroleum target is gas-hydrate reservoirs, which contain gas in a solid, icelike form. Occurrences of such hydrates have been identified on Alaska's North Slope, and the technology for eharacterizing and developing this resource is under study as part of the DOE's Environmental and Advanced Research subprogram. Subprogram efforts have recently been concentrating on laboratory testing of natural and synthetic hydrates to define the pressure and temperature conditions and geophysical and mechanical properties in both inhouse and contractors' facilities (Morgantown Energy Technology Center, 1987b). Arctic onshore and offshore research studies to determine the inplace conditions of gashydrate deposits have been initiated by the DOE in cooperation with the USGS as well as with ARCO Alaska, Standard Oil Co., and CONOCO.

The DOE's research on deep-source gas is focused on evaluating the potential for recovering gas from depths greater than $30,000 \mathrm{ft}$, based on the hypothesis that natural gas would be generated in sediments carried to these depths by tectonic processes. Primary reservoir targets are former subduction zones where suitable sediments have been encapsulated. One of the study areas is Yukon Flats near Fairbanks (no. 9, fig. 7), where cooperative stratigraphic, structural, and magnetotelluric studies are under way (Morgantown Energy Technology Center, 1987c). The DOE has also sponsored a search for such gas sources in south-central and southwestern Alaska through the University of Alaska.

\section{Arctic National Wildlife Refuge}

The first multidisciplinary compilation of Federal reports on the ANWR was released to the public in 1986 (U.S. Fish and Wildlife Service and others, 1986). This report is the culmination of several years of Congressionally mandated studies.

The Arctic National Wildlife Range was created in 1960 by Public Land Order 2214, encompassing 8.9 million acres of northeastern Alaska. In 1980, with the enactment of ANILCA, this unit was enlarged to 18.06 million acres and renamed the Arctic National Wildife Refuge. Subsequently, other additions, including the utility corridor immediately south of the original range, have increased the size of the ANWR to about 19.5 million acres. Also in ANILCA, Congress designated approximately 8 million acres of the ANWR as wilderness to be managed under the terms of the Wilderness Act (78 Stat. 892).

In Section 1002 of ANILCA, Congress: mandated a comprehensive and continuing inventory and assessment of the fish and wildlife resources on an approximately 1.5-million-acre strip of coastal plain, now known as the 1002 area, between the Staines-Canning River boundary of the ANWR and the Aichilik River (figs. 8, 9); required an analysis of the environmental impact of oil and gas exploration, development, and production; and authorized exploratory activity within the 1002 area in a manner that would avoid significant adverse effects on the fish and wildlife and other resources. That section required the Secretary of the Interior:

1. To conduct a baseline study: to assess the size, range, and distribution of the populations of fish and wildlife; to determine the extent, location, and carrying capacity of the habitats of the fish and wildlife; to assess the impacts of human activities and natural processes on the fish and wildife and their habitat; and to analyze the potential impacts of oil and gas exploration, development, and production on such wildlife and habitats, and on the culture and lifestyle of affected Native and other peoples; and

2. To prepare and submit, not earlier than December 2,1985 , and not later than September 2, 1986, a report to Congress containing: the identification, by means other than drilling of exploratory wells, of those areas within the 1002 area that have oil and gas production potential, with estimated volumes; the description of the fish and wildlife, their habitats, and other resources within such areas; and an evaluation of the adverse effects that the carrying out of further exploration for, and the development and production of, oil and gas within such areas will have on the resources described. This report shall also contain: a description of how such oil and gas may be transported to processing facilities; an evaluation of how such oil and gas relates to the national need for additional oil and gas; and recommendations as to whether further exploration, development, and production should be permitted and, if so, 


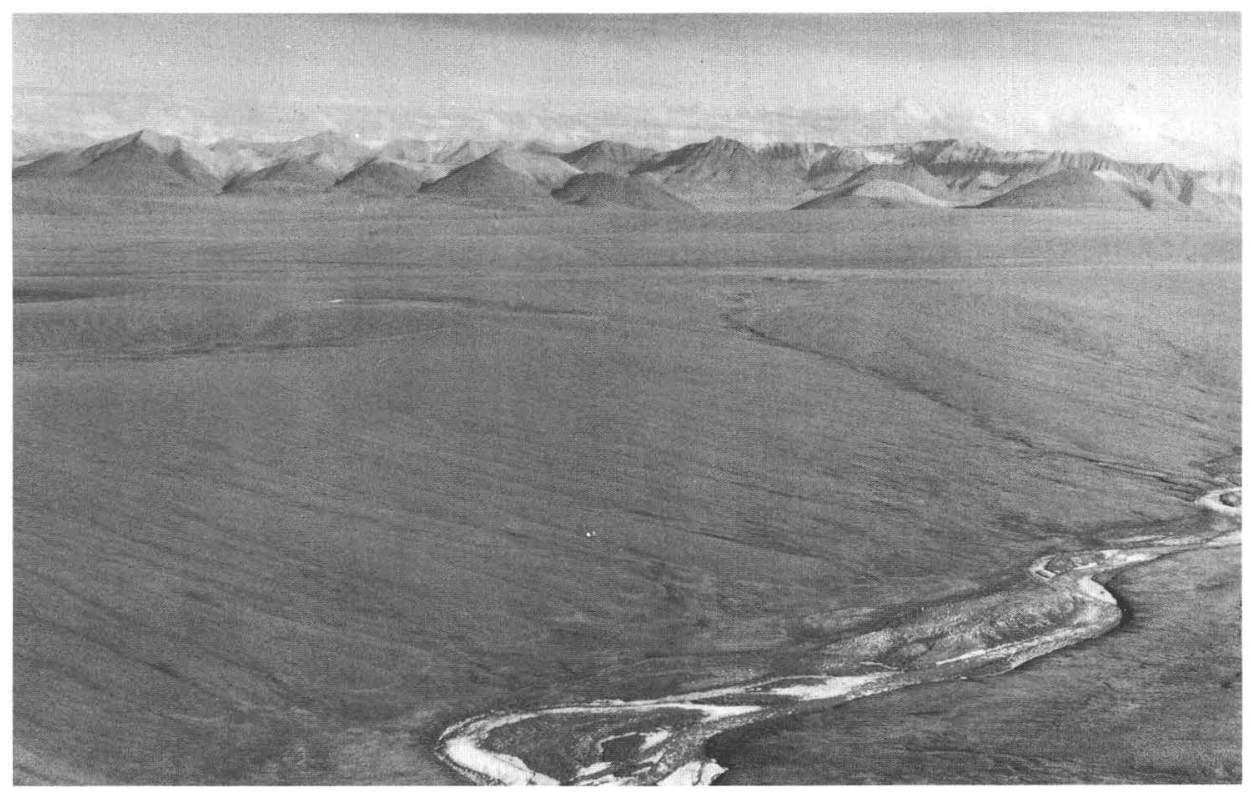

Figure 8.--1002 area of the Arctic Coastal Plain, Arctic National Wildlife Refuge, is subject of a petroleum assessment. Sadlerochit Mountains in background are part of a designated wilderness area. Photograph courtesy of Fish and Wildlife Service.

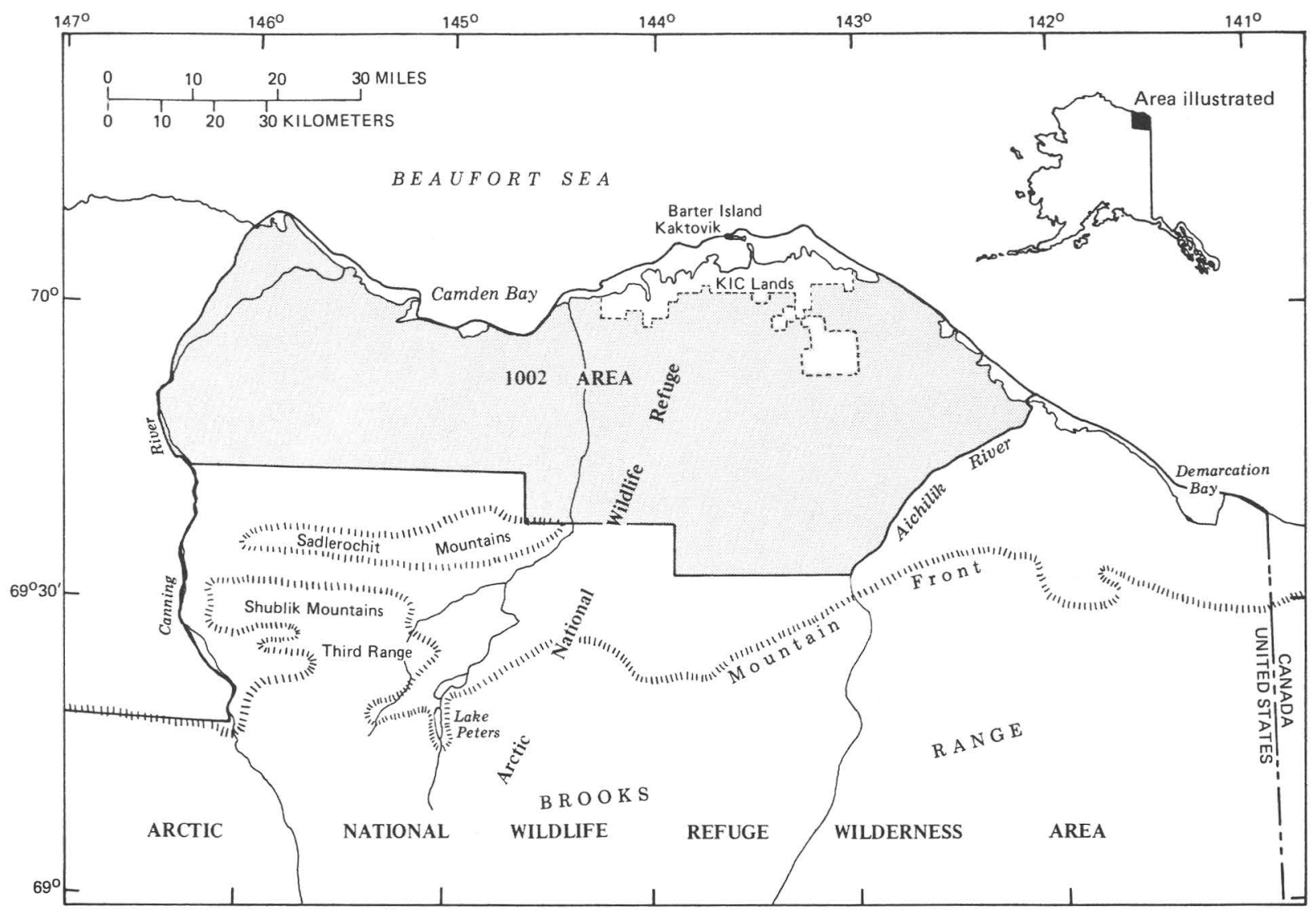

Figure 9.--Location of Arctic National Wildlife Refuge 1002 area. KIC, Kaktovik Inupiat Corp. lands. 
what additional legal authority is necessary to ensure that the adverse effects of such activities are avoided or minimized.

The FWS is the overall coordinator of the Section 1002 resource assessment. In June 1983, an interagency memorandum of understanding was negotiated that provided for assistance from the BLM and the USGS in assessing the hydrocarbon potential of the 1002 area of the coastal plain and in preparing the report to Congress. An Interagency Review Panel, composed of representatives from these three agencies and chaired by the FWS, was formed to review and make recommendations concerning the proposals from industry to conduct geologic studies and geophysical surveys in the 1002 area. An Interagency Advisory Work Group, composed of representatives from the same agencies and again chaired by the FWS, was formed in March 1984 to oversee preparation, including the writing of some sections, of the report. This group called on more than 50 scientists from the Department of the Interior to provide data and analyses of the biologic, physical, cultural, and economic environments; conduct geologic and geochemical investigations; and provide interpretations and analyses of the geophysical surveys, principally seismic and gravity, for the Secretary's report to the Congress.

Fish and Wildlife Service

The FWS conducted baseline studies, as directed by the Congress, from 1981 to 1985 . These studies focused on defining: (1) the ecology, distribution, and abundance of fish and wildlife species (fig. 10); (2) wildlife habitats within the 1002 area; and (3) the impacts of seismic exploration on tundra vegetation. An initial baseline report on fish, wildlife, and habitat resources was prepared by Garner and Reynolds, (1983), with annual updates for field studies from the years 1983-84 (Garner and Reynolds, 1984, 1985); a report summarizing these results was prepared by Garner and Reynolds (1986).

Under FWS special permits, Geophysical Service, Inc., sponsored by 23 participants the first season and by 21 participants the second season, conducted group seismic surveys during the winter-spring months of 1984 and 1985. A total of 760 line-miles of seismic data, with associated gravity observations, was obtained in 1984, and 573 line-miles of Vibroseis seismic data in 1985 .

Geologic field parties from 13 different companies collected surface geologic information in the 1002 area during the summers of 1983-85. International Technology, Ltd./Photogravity Co. was authorized to obtain gravity readings on an approximately 1-by-2-mi grid spacing over the entire 1002 area in fall 1983; approximately 1,300 gravity readings were obtained during this survey. Chevron Alaska, Inc., conducted a surface geologic study on the adjacent wilderness area under a special use permit in 1986. Also under a special use permit, two towers were erected in the

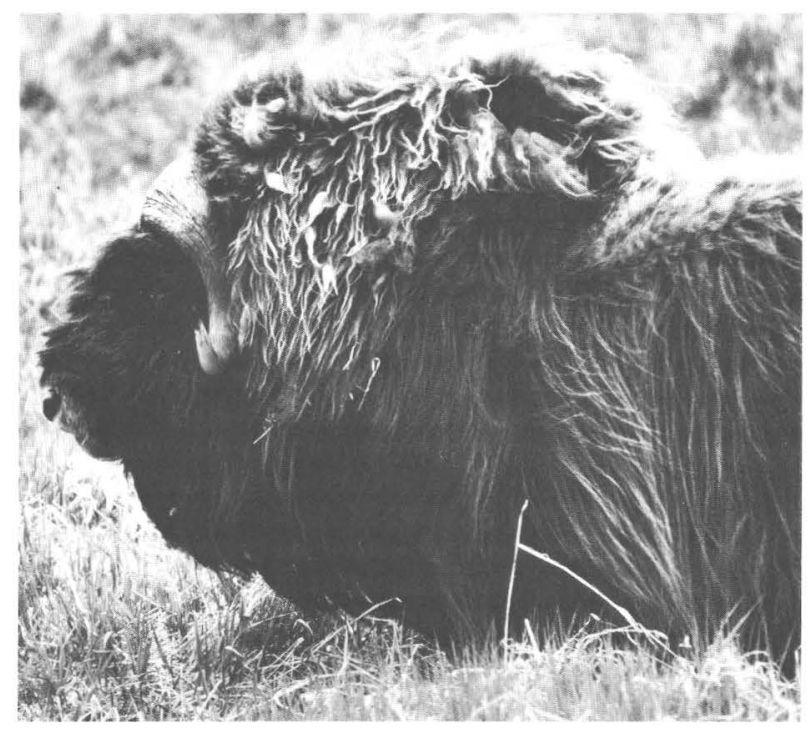

$$
\begin{aligned}
& \text { Figure 10.-- The musk ox is one of the } \\
& \text { inhabitants being studied in the } \\
& \text { Arctic National Wildlife Refuge } \\
& 1002 \text { area. Photograph courtesy } \\
& \text { of Fish and Wildlife Service. }
\end{aligned}
$$

ANWR as navigation aids for offshore oil and gas exploration and drilling activities. All exploration activities were closely monitored by the FWS, and all companies were required to submit copies of the data obtained as a result of their studies. The confidentiality of those data is addressed under the regulations that govern the 1002 area exploration program.

A lawsuit filed by a coalition of environmental organizations (Trustees for Alaska, American Wilderness Alliance, Defenders of Wildlife, Northern Alaska Environmental Center, and the Wilderness Society) delayed submission of the report to the Congress. The court ruling in the organizations' favor was upheld upon appeal. That 1986 ruling required the FWS to prepare an EIS and to solicit public comments before the Secretary's submission of the report to the Congress.

The draft, "Arctic National Wildlife Refuge, Alaska, Coastal Plain Resource Assessment, Report and Recommendation to the Congress of the United States and Legislative Environmental Impact Statement," was released on November 24, 1986 (U.S. Fish and Wildlife Service and others, 1986). The public-comment period extended through February 6, 1987, and three hearings were held on the report: January 5, 1987, in Anchorage, Alaska; January 6 in Kaktovik, Alaska; and January 9 in Washington, D.C.

More than 11,000 letters were received during the public-comment period. Approximately two-thirds favored opening the 1002 area of the coastal plain to oil and gas leasing; one-third supported no development and a wilderness designation for the area. 
The final report was released on April 20, 1987 (Clough and others, 1987). It includes a separate 998-page volume of all substantive comments received from the public, as well as various opinion letters and substantive written testimony received at the public hearings. The Secretary of the Interior confirmed the draft recommendation of the Assistant Secretary for Fish and Wildlife and Parks. His recommendation is that the Congress authorize full leasing of the 1002 area, in an orderly oil and gas leasing program which avoids unnecessary adverse effects on the 1002 area's wildlife, habitat, and environment.

\section{Bureau of Land Management}

The BLM's cooperative contribution to the ANWR 1002 area studies, mandated under ANILCA, and to the Secretary's report to the Congress included geophysical mapping of geologic structures with the potential for economically recoverable oil and natural gas resources, delineating the infrastructure required to get the potential resources to a point of transshipment to market, and evaluating the relation of those potential resources to the national needs for domestic oil and gas resources. Specific studies and accomplishments included:

1. Participation on the FWS-BLM-USGS Interagency Review Panel for proposed geological and geophysical exploration plans;

2. Participation on the FWS-BLM-USGS Interagency Advisory Work Group and assistance in the preparation of, and in the reviews of, the various sections of the Secretary's report;

3. Analyses and interpretations of geophysical survey data, principally seismic, provided by industry; the integration, in conjunction with the USGS, of these interpretations with geologic information provided from surface outcrops and from well logs in adjacent areas; and the preparation of time, depth, and isopach maps for the 1002 area;

4. Seismic delineation and mapping of 26 significant oil and (or) gas prospects on, or generally within, the 1002 area boundaries;

5. Participation with the USGS in developing the assessment of both potential inplace and potential recoverable petroleum resources in the 1002 area;

6. Projection of an exploration (drilling), development, production (with associated infrastructure), and transportation scenario, including a generalized pipeline routing, for bringing any discovered and economically recoverable petroleum resources to market;

7. Assessment of various options, with an evaluation of their engineering, environmental, and economic advantages and disadvantages, for transportation of petroleum from the 1002 area;

8. Determination of threshold oil-field sizes for economic viability under various assumed crude-oil market prices, inflation rates, discount rates, and royalty rates; and

9. Assessment of the effect of major oil and (or) gas discoveries within the 1002 area on the national security and flexibility for independent action, the Nation's economic health, and balance-of-payments problems at the turn of the century.

\section{U.S. Geological Survey}

The USGS' cooperative contribution to the ANWR 1002 area studies, mandated under ANILCA, and to the draft of the Secretary's report to the Congress included determination of the geologic framework, geologic trends and stratigraphic relations, petroleum geology, potential development in conjunction with the BLM, and a resource assessment, as well as a description of the physical environment of the 1002 area. Specific studies and accomplishments included:

1. Participation on the FWS-USGS-BLM Interagency Review Panel for proposed geologic and geophysical exploration plans;

2. Participation in the FWS-USGS-BLM Interagency Advisory Work Group and assistance in the preparation of, and in the reviews of, the various sections of the Secretary's report;

3. Geologic fieldwork, including rock sampling for organic and other chemical analyses, at various localities within the 1002 area and in adjacent areas where rock formations, anticipated to underlie the $\mathbf{1 0 0 2}$ area, crop out;

4. Reconnaissance snow and spring-discharge surveys, and computation of drainage areas, maximum flood discharges, unit runoffs, 2and 50-year-flood characteristics, for major streams within the 1002 area;

5. Preparation, in cooperation with the FWS and the U.S. Army's Cold Regions Research and Engineering Laboratory, of "Vegetation and Land Cover" maps (1:250,000 scale) for the 1002 area, using digital Landsat multispectral-scanner and digital-terrain data (Acevedo and others, 1982);

6. Preparation of "Engineering-Geologic Maps of Northern Alaska Coastal Plain and Foothills of the ANWR," including generalized surficial deposits of the 1002 area, on a 1:250,000 scale (Carter and others, 1986);

7. Preparation of a newly compiled geologic map (1:250,000 scale) of the 1002 area, the continuation of the coastal-plain areas to the east and to the west, and the mountainous areas, with outcrops of significance to 1002 area studies, to the south (Bader and Bird, 1986);

8. In cooperation with BLM geoscientists, determination of the geologic-structural framework, identification of regional and local geologic trends and stratigraphic relations, and integration of surface geology with the geophysical survey data, principally seismic, provided by industry to analyze the petroleum potential of the 1002 area; and 
9. Development, with assistance from the BLM, of estimates of both potential inplace and potential recoverable petroleum resources in the 1002 area.

A collection of 23 technical reports, summarizing the petroleum geology used in assessing the oil and gas resources of the 1002 area, will be published as U.S. Geological Survey Bulletin 1778 (Bird and Magoon, 1987). That volume will provide a technical supplement to the report to the Congress.

\section{COAL AND PEAT}

Alaska's 1986 coal production was 1.49 million tons (up 190,000 tons from 1985), with exports at 700,000 tons (up 105,000 tons from 1985) (Bundtzen and Green, 1987), in spite of a forecast by the Independent Petroleum Association of America predicting a 1-percent decline in 1986 for U.S. coal production (Alaska Report, Nov. 5, 1986). Alaskan coal production in 1986 was valued at $\$ 40.1$ million, an increase of $\$ 37,000$ over the 1985 value, and the fourth most valuable mineral commodity to the State of Alaska.

During 1986, industrial activity focused on three Alaskan coal fields: Beluga, Healy, and Jarvis Creek (fig. 13). The Diamond Alaska Coal Co. plans to drill 36 coreholes in their Beluga resource-area lease beginning in 1987, to add statistical confidence to the company's coalquality information (Alaska Journal of Commerce and Pacific Rim Reporter, Mar. 17, 1986). Usibelli Coal Co., located near Healy (fig. 13) and the only active coal mine in Alaska, produced 1.49 million tons of coal in spite of a March 1986 fire in the conveyor system in their loading facility, and October floods that washed out sections of the Alaska Railroad tracks south of Anchorage. The railroad is used by Usibelli to haul coal to the port of Seward for loading onto transport ships bound for Korea. In 1986, half of the coal Usibelli produced was sold in Alaska to supply electrical power and heating needs, and the remaining 700,000 tons was exported to Korea (Alaska Journal of Commerce and Pacific Rim Reporter, Feb. 9, 1987). In January 1987, exports were halted for a limited time, owing to a temporary glut of coal at the powerplant in South Korea. Shipments are expected to resume in March (Anchorage Daily News, Jan. 29, 1987). Usibelli Coal Co. is currently attempting to expand their market, both instate and to other Pacific Rim countries (Alaska Journal of Commerce and Pacific Rim Reporter, Feb. 9, 1987). The Delta Coal Co., holder of a BLM preferential lease in the Jarvis Creek coal field (fig. 13), has completed feasibility studies for mining coal. At present, they do not have a surface-mining permit or a firm market. The coal is reported to have a low sulfur content ( 0.42 to 1.5 weight percent) and an appar- ent rank of subbituminous $B$ to $C$.

The ADGGS continued its investigation of the Chicago Creek coal field on the Seward Peninsula (fig. 13). Feasibility studies on supplying coal to nearby villages for heat, as well as for fuel to a powerplant, have been completed (Retherford and others, 1986). Articles in Petroleum Information's Alaska Report (May 14, 1986) and the Alaska Journal of Commerce and Pacific Rim Reporter (Sept. 1, 1986) note that the Deadfall syncline area (fig. 13) in the northern Alaska coal fields can supply coal for heating to local villages for at least 100 years. Detailed environmental studies are ongoing. Current plans call for surface mining 6 months per year at a rate of 50,000 tons/yr; the coal will be trucked to nearby Omalik Lagoon and stockpiled to be barged to coastal villages.

Peat mined in Alaska is used primarily in agriculture and greenhouses as a soil conditioner; minor amounts are burned locally in villages for heat. Because of the continued slump in Alaskan housing construction, peat production for use by housing contractors was only $50,000 \mathrm{yd}^{3}$, about 41 percent less than in 1985 (Bundtzen and Green, 1987).

\section{Activity by Federal Agencies}

\section{U.S. Geological Survey}

The USGS investigated the quality and quantity of coal in the Chandler Lake $1: 250,000-$ scale quadrangle (fig. 13) in the southeastern part of the Northern Alaska coal field as part of AMRAP. Coal of Cretaceous age in the north third of the quadrangle has low contents of sulfur (0.13-0.56 weight percent) and ash (2.7-15.4 weight percent), and an apparent rank of high-volatile bituminous A to high-volatile bituminous $\mathrm{C}$. Also as part of AMRAP, coal of Tertiary age in the Nenana coal field has been mapped in the Healy $1: 250,000$-scale quadrangle in central Alaska (fig. 13; Csejtey and others, 1986).

Coal of Late Cretaceous to Tertiary age in the eastern part of the Northern Alaska coal field (fig. 13) has been sampled as part of the USGS Sedimentary Basins program. This program includes studies of depositional, structural, diagenetic, and thermal processes useful in resource analyses. Preliminary results of two coal cores from the Sagwon Bluffs along the Sagavanirktok River (fig. 11) indicate that these Tertiary coals have a mean sulfur content of 0.12 weight percent (0.08-0.17 weight percent), a mean ash content of 8.0 weight percent (2.7-16.4 weight percent), and a mode apparent rank of subbituminous $B$ (range of lignite $A$ to subbituminous $B$ ). Efforts to correlate coal beds (both surface and subsurface), evaluate the size of the resource area and determine depositional environments are continuing (Stephen Roberts, written commun., 1987).

Coals from the Nenana field near Healy (fig. 13) have been evaluated as petroleum sources. These Tertiary coals can be considered as 


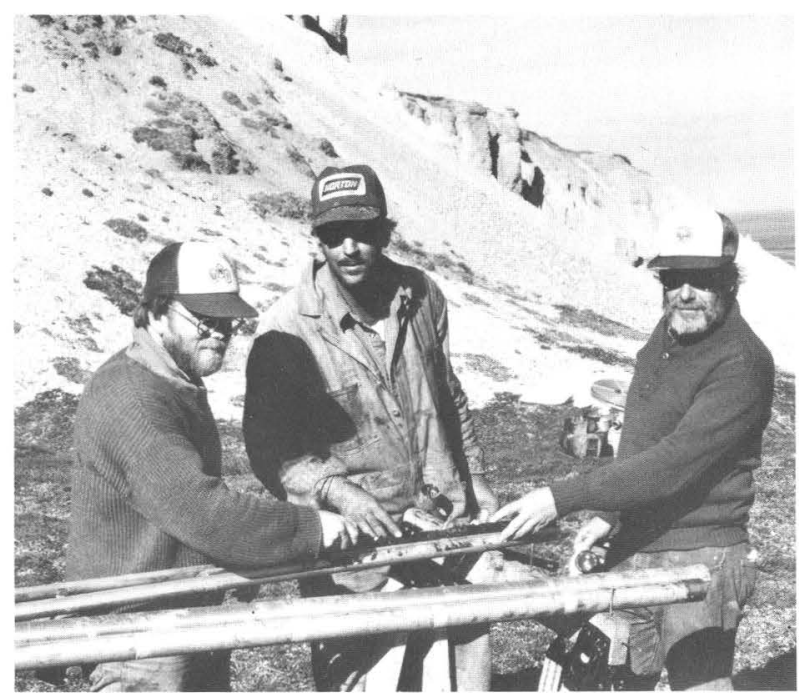

Figure 11.--U.S. Geologica 1 Survey geologists examine coal cores at the Sagwon Bluffs on the North Slope. Photograph by A.C. Clark.

potential sources of gas and possibly oil, but they are thermally immature (Stanley, 1987a). The horizontal and vertical variation across the stripmine face of coal beds in the Usibelli mine have also been studied (fig. 12). The upper part of the No. 3 coal bed shows a marked increase in the contents of beryllium, chromium, molybdenum, niobium, scandium, sulfur, vanadium, ytterbium, and yttrium, due to an interaction of oxygencharged ground-water solutions that came in contact with the upper part of the coal bed and, in part, to plant takeup of selected elements as nutrients in the original peat swamp (R.H. Affolter and G.D. Stricker, written commun., 1987).

The USGS has been investigating the thickest known coal bed in the State. The 185 -ft-thick bed is located on the Seward Peninsula in the Death Valley area (fig. 13). This Eocene coal bed is overlain by basalt and underlain by uraniumenriched floor rock. The apparent rank ranges from low-volatile bituminous A near the top of the bed to subbituminous A near the base (G.D. Stricker, written commun., 1987).

The USGS is continuing its investigations of the Beluga resource area on the west side of Cook Inlet (fig. 13). The coal there has an apparent rank of subbituminous $\mathrm{C}$ to $\mathrm{B}$, a low sulfur content (0.08-0.33 weight percent), and varying ash content (4.7-46.5 weight percent) (Stricker and others, 1986). The coal-ash mineralogy contains mainly kaolinite and minor mica-type clays, varying amounts of quartz, and seattered occurrences of the phosphate mineral goyazite (M.E. Brownfield, written commun., 1987). This information will provide background data for the future coal development envisioned by the Diamond Alaska Coal Co.

\section{Bureau of Land Management}

The BLM continued its management of the Delta Coal Co.'s lease in the Jarvis Creek coal field south of Delta Junction (fig. 13). Coal from this field is a potential feed stock to produce gas, which, in turn, would be used to generate electrical power for the U.S. Army base at Fort Greeley, south of Delta Junction. Interest in additional coal leasing on Federal land is low at this time.

\section{Fish and Wildlife Service}

The North Slope Borough conducted a phase II feasibility assessment for western Arctic coal

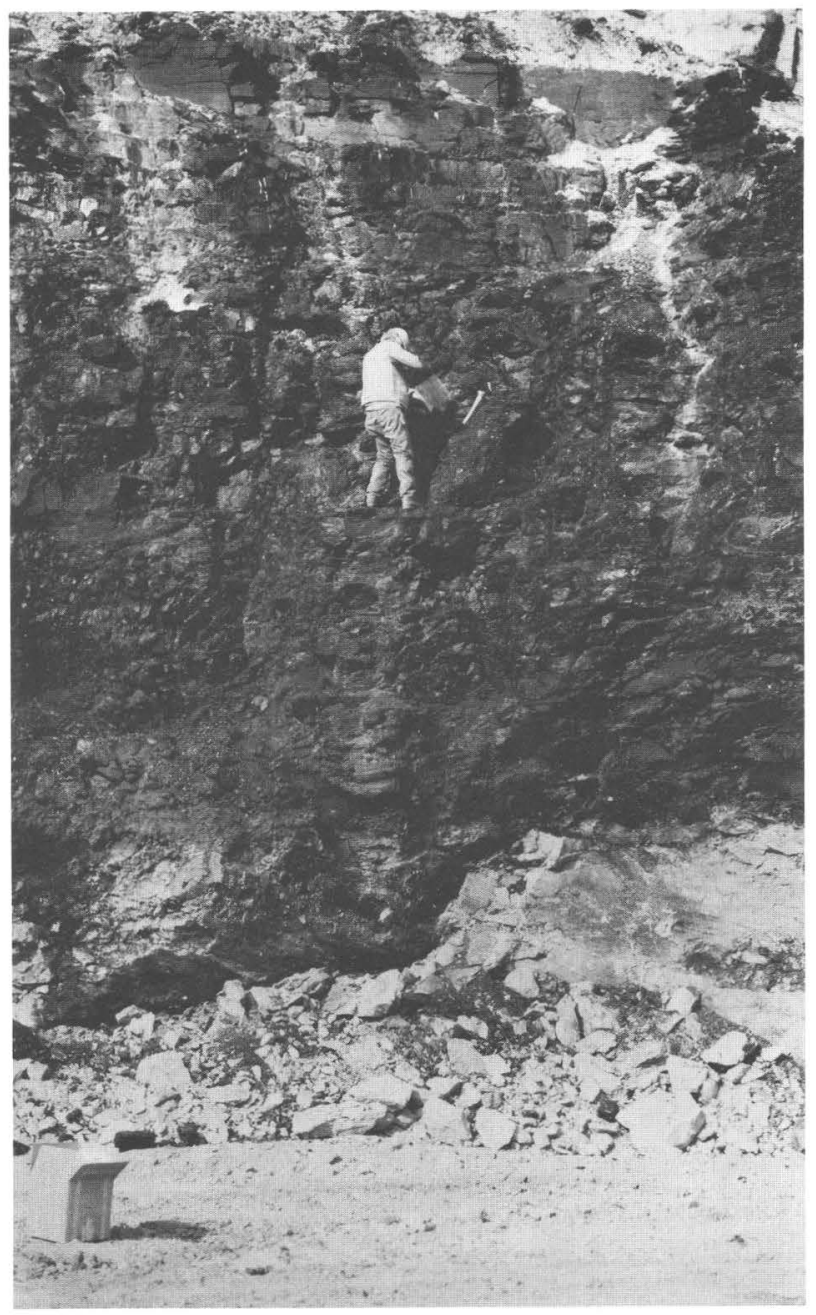

Figure 12.--U.S. Geological Survey geologist examines a coal seam at the Usibelli Coal Mine, Inc. Photograph by R.H. Affolter. 


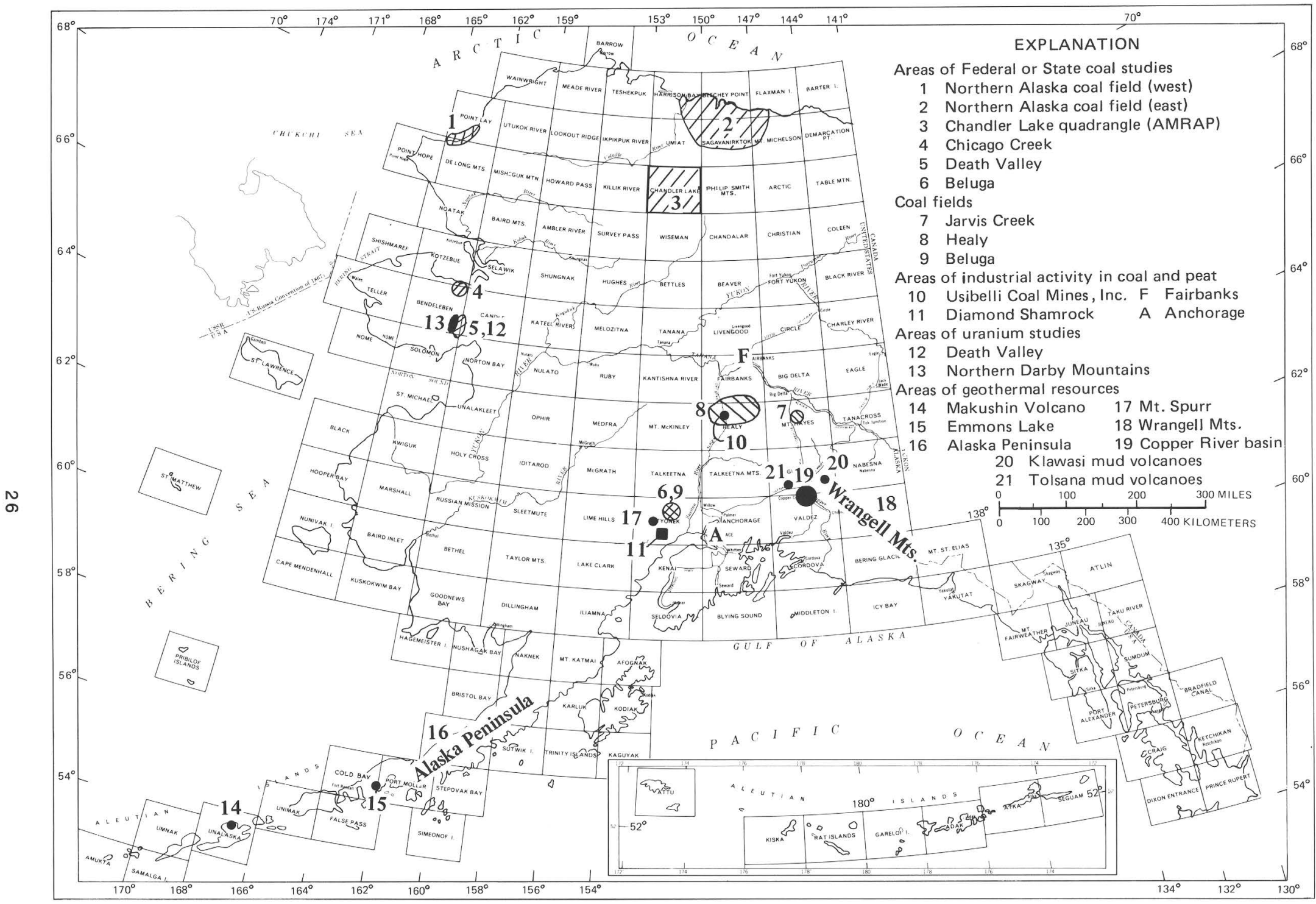

Figure 13.--Areas of potential coal and peat, uranium, and geothermal resources mentioned in text. 
development on Native inholdings in the NPRA. The FWS provided input to this planning report relative to environmental concerns in the area.

\section{Department of Energy}

The DOE is examining coal resources in Alaska as part of its Arctic and Offshore Research subprogram. The goal of this subprogram is to evaluate coal in terms of its contribution to the national resource base. The DOE also is actively studying coal-bed methane on a nationwide basis, and has sponsored research projects through the University of Alaska that investigate means of liquefying certain Alaskan coals and the beneficiation potential (for improvement of the ore grade) of coals crushed to various fragment sizes.

\section{URANIUM}

Despite a 7-year decline in uranium exploration in the United States, the uranium industry appears to have stabilized during 1986 . Imported uranium is a problem for domestic producers and continues to supply about 40 percent of U.S. requirements. In 1986, $\$ 17$ million was spent on uranium exploration in the United States, and about 14 million $\mathrm{lb}$ of $\mathrm{U}_{3} 0_{8}$ was produced (Chenowith, 1986).

There was no uranium exploration or production in Alaska during 1986. High exploration and production costs in the State discourage uranium activity during periods of low or moderate demand. However, certain kinds of potential uranium deposits could be of interest, such as surficial-deposits where exploration and development costs are generally low.

\section{Activity by Federal Agencies}

\section{U.S. Geological Survey}

Few reports specifically on uranium are being prepared by the USGS. However, reports being prepared for current mineral-assessment studies may include uranium along with other commodities.

\section{U.S. Bureau of Mines}

The USBM published a report on uranium occurrences in the northern Darby Mountains on the Seward Peninsula of Alaska (Foley and Barker, 1986). Although no uranium ore deposits are known in the Darby Mountains, a local granite is considered to be the source of the sedimentaryrock-hosted uranium at the Death Valley prospect, which occurs in the Death Valley sedimentary basin adjacent to the Darby Mountains (Dickinson and Cunningham, 1984).

\section{GEOTHERMAL RESOURCES}

Alaska's geothermal resources are currently used on a small, highly localized scale for recreation, space heating, and agriculture. Potential sources of geothermal energy are widespread, as indicated by present and former volcanic activity on the Aleutian Islands, the Alaska Peninsula, the Wrangell Mountains, and elsewhere in the State (fig. 13). Such geothermal areas as Mount Spurr, which are close to existing power-transmission networks, are potential sources of power for the population centers of Alaska, whereas other areas, such as those in the Aleutians, may find principal application as power sources for the fishing industry.

The Alaska Department of Natural Resources, Division of Oil and Gas held a geothermal lease sale for the Mount Spurr area on June 24, 1986. Two tracts, totaling 2,628 acres, were offered and attracted three bids; a previous sale in 1983 attracted one bid for 640 acres. The 10-year geothermal-prospecting leases are renewable if production is obtained.

Makushin Volcano, near Dutch Harbor and Unalaska, has long been considered a potential source of geothermal power. Studies of Makushin funded by the Alaska Power Authority and the DOE have helped to delineate the resource. As a followup to those studies, an engineering-geologic site evaluation of the area of a proposed powerplant and the transportation corridors from it has recently been completed by the ADGGS (Updike, 1986).

\section{Activity by Federal Ageneies}

\section{U.S. Geological Survey}

The USGS began detailed mapping at Emmons Lake caldera (fig. 14) in 1986. Estimates by Smith and Shaw (1975) indicate that the Emmons Lake system may have one of the highest igneous-related heat contents in the Aleutian voleanic are; MeNutt and Jacob (1986) reported seismic evidence for the presence of a crustal magma chamber beneath Emmons Lake. Geologic mapping will provide more reliable data on the ages and volumes of silicic eruptions, which will refine estimates of the resource base.

\section{Department of Energy}

The DOE provided funds in fiscal year 1985 for investigation of the geothermal-resource potential of Mount Spurr, and these studies continued in 1986. The cooperative project by the ADGGS and the University of Alaska included mapping and dating of volcanic deposits and chemical and geophysical surveys. Their work documented the presence of a long-lived magmatic system (not necessarily a high-level magma chamber), identified areas of thermal springs and fuma- 


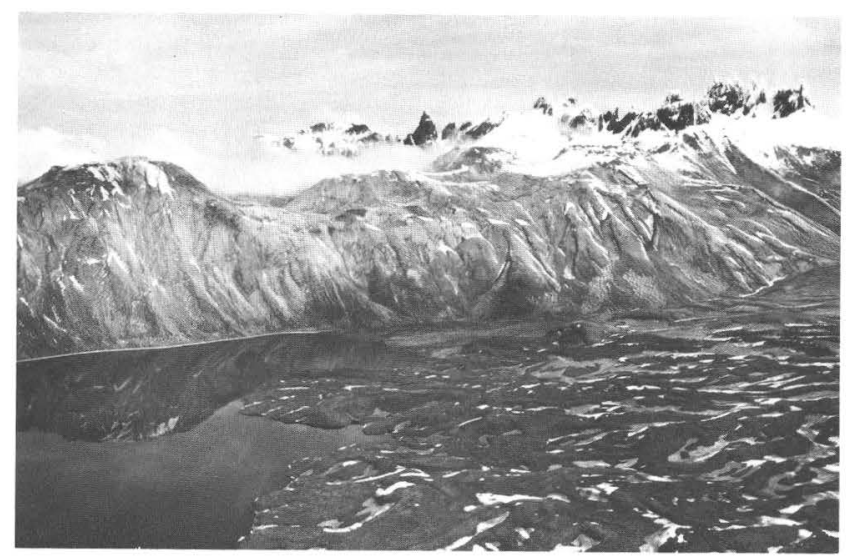

Figure 14.--Emmons Lake caldera east of Cold Bay is subject of U.S. Geological Survey geothermalresource research. View shows western caldera wall and Aghileen Pinnacles in background. Photograph by M.E. Yount.
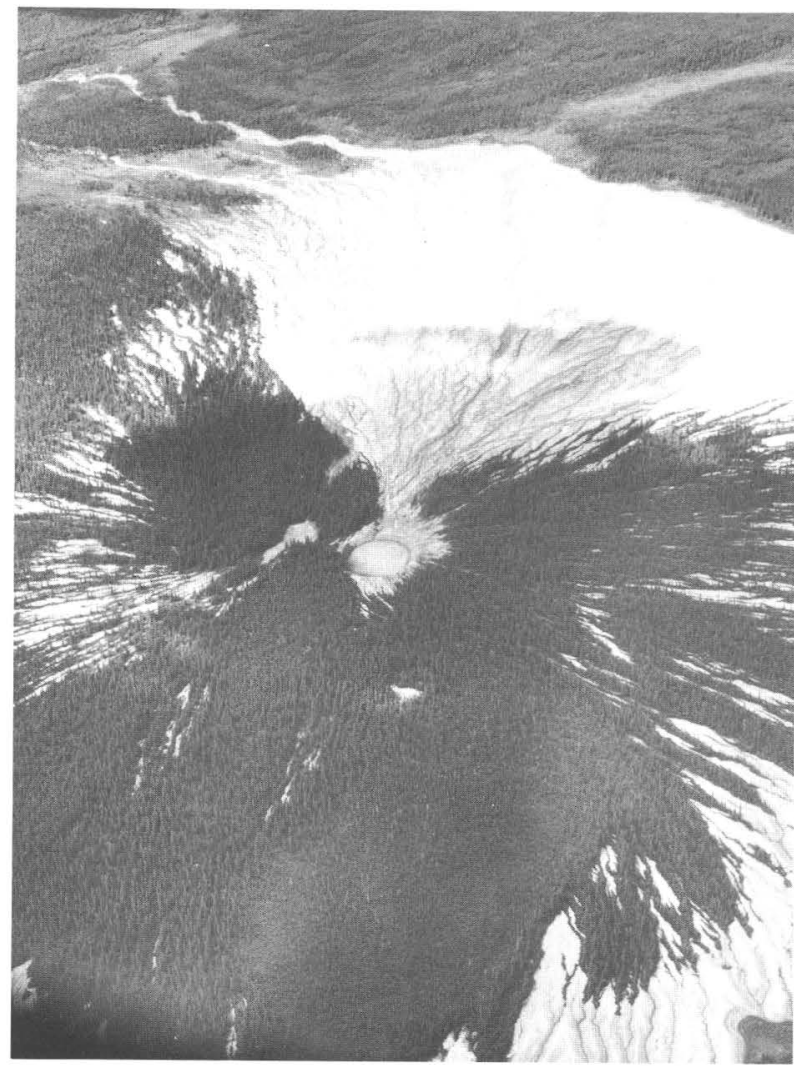

Figure 15.--Klawasi mud volcano in the Copper River basin is one target of Department of Energysponsored research. Photograph by T.P. Miller. rolic activity, and delineated targets for further study (Turner and Wescott, 1986).

A DOE-funded study of the Tolsona and Klawasi mud volcanoes (fig. 15) in the Copper River basin by Motyka and others (1986) examined the chemistry of gases and waters from the two areas, to determine whether a geothermal resource is present. Applicable chemical geothermometers indicate that Klawasi reservoir temperatures are $100-125{ }^{\circ} \mathrm{C}$, whereas those at Tolsona are $50-60{ }^{\circ} \mathrm{C}$. Chemical and geophysical evidence suggests that an igneous intrusion beneath Klawasi may be 2.5 to $3.0 \mathrm{~km}$ deep. Both areas are presently considered subeconomic for geothermal-resource development.

\section{NONFUEL-MINERAL RESOURCES}

\section{METALLIC MINERALS}

\section{Industry Activity}

Overall, the national and worldwide metals market remained depressed in 1986. Preciousmetal prices were relatively stable; consequently, industry exploration activity in Alaska in 1986 concentrated on gold and, to a lesser degree, platinum.

A total of 5,315 new mining claims were filed in Alaska during 1986, in comparison with 6,773 in $1985--a$ decrease of 22 percent. The number of active claims maintained in 1986 was 71,024 , in comparison with 81,782 for $1985^{--a}$ decrease of 14 percent.

Data obtained by the State of Alaska (Bundtzen and Green, 1987) indicate that statewide production of metals totaled about $\$ 62$ million in 1986 (table 3), a decrease of about 0.3 percent relative to 1985 . Gold accounted for 98 percent of the 1986 value. A total of 195 mechanized placer gold mines were in operation in 1986 , in comparison with 266 in 1985--a drop of 27 percent. Gold production in 1986 was 160,000 troy oz, in comparison with 190,000 troy oz in $1986--a$ decrease of 16 percent. Because the average price of gold increased from about $\$ 320 /$ troy oz in 1985 to about $\$ 380 /$ troy oz in 1986 , the dollar value of gold produced in $1986(\$ 60,800,000)$ decreased only 0.3 percent from the 1985 value $(\$ 61,175,000)$.

The reason for the decrease in the number of operating placer gold mines in 1986 is complex. The most significant factor is increased enforcement of enviromental regulations regarding the quality of water discharged from the mines. Three national parks and preserves were effectively closed to mining in 1986 owing to litigation (see next subsection). A total of 30 mining operations employing 175 people were unable to operate in 1986 because of this lawsuit (Bundtzen and Green, 1987).

Areas of important industry activity in 1986 are shown in figure 17. 
Table 3.--Mining production in Alaska, 1984-86.

[Assumed average prices: sand and gravel, \$3.75/ton, varying with 1ocation; gold, \$380/troy oz; coal (FOB Healy), \$26.86/ton; building stone, $\$ 4.80 /$ ton; peat, $\$ 7 / \mathrm{yd}^{3} ;$ silver, $\$ 5.06 / \mathrm{troy}$ oz; antimony $\$ 1.50 / 1 b$; tungsten, $\$ 190 /$ ton; mercury, $\$ 300 /$ flask. Prices not available for tin or jade. Data from Bundtzen and Green (1987)]

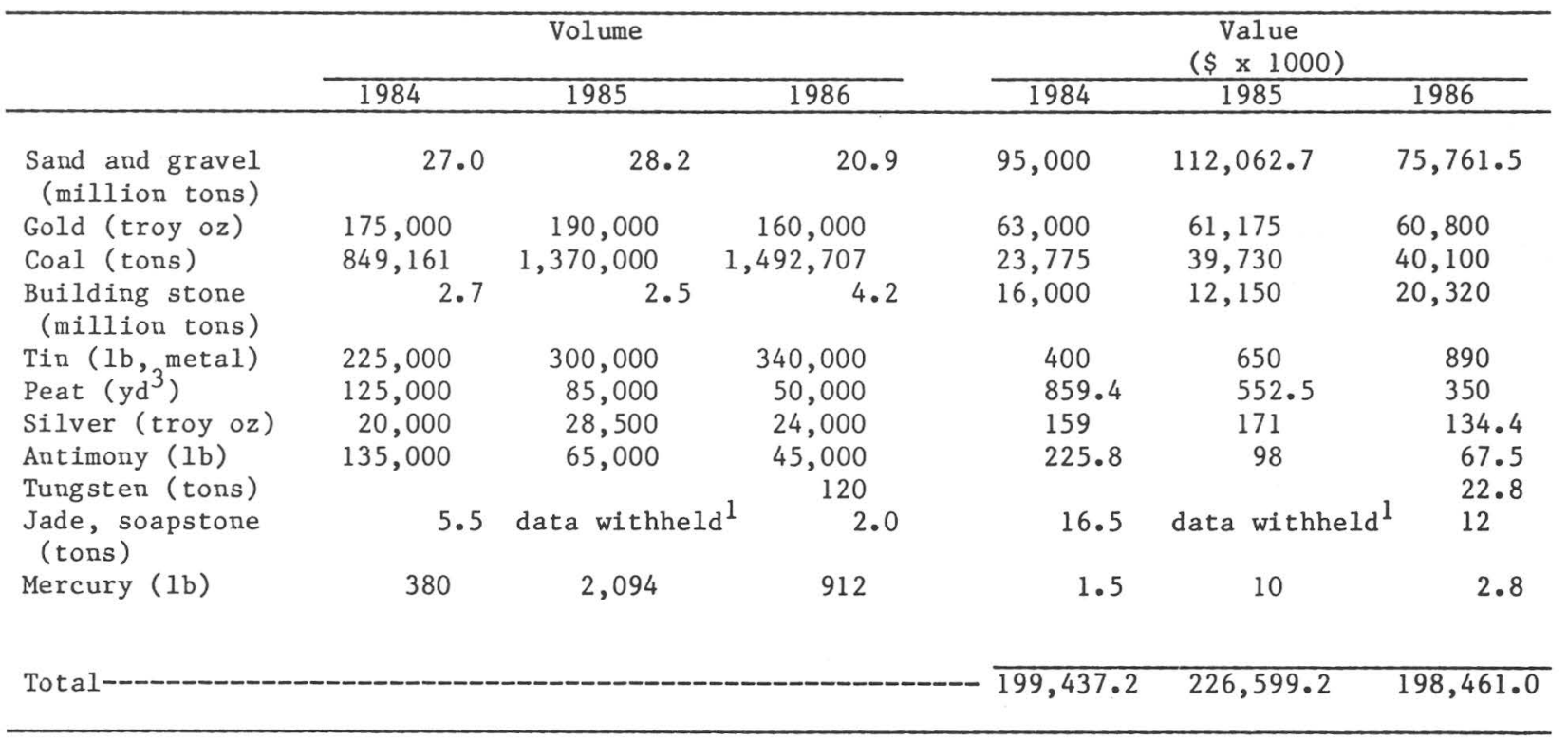

${ }^{1}$ Information withheld by mine operators

\section{Precious Metals}

The most significant precious-metals development in Alaska in 1986 was the onset of offshore mining near Nome by Inspiration Gold, Inc. (IGI). After a successful sampling program in 1985, IGI purchased and moved a large offshore dredge, the Bima, from Indonesia in July 1986. Thę Bima (fig. 16 ) is capable of processing $40,000 \mathrm{yd}^{3} / \mathrm{d}$ of sand and gravel. Actual mining was hampered by unusually bad weather and shortcomings in the circuit for handling the concentrates; still, the venture was considered encouraging enough for IGI to barge the dredge to Seattle for refitting during winter 1986-87. The project employed 66 people during operation from July to October, 44 of whom were Nome residents. In 1986, Nerco Minerals Co. and Meridian Minerals Co. signed an agreement to conduct exploration for gold and other metals in Alaska (Alaska Journal of Commerce and Pacific Rim Reporter, May 5, 1986). Actual exploration was to be carried out by Research Associates of Alaska (Fairbanks, Alaska), a wholly owned subsidiary of Nerco. On December 18, 1986, Nerco announced plans to relocate most of its geologists to Vancouver, Wash., reducing the size of the Fairbanks office by 75 percent.

Several Canadian companies explored for precious metals in Alaska in 1986. Queenstake Resources acquired lease rights to the Chichagof and adjoining Hirst-Chichagof mines near Juneau

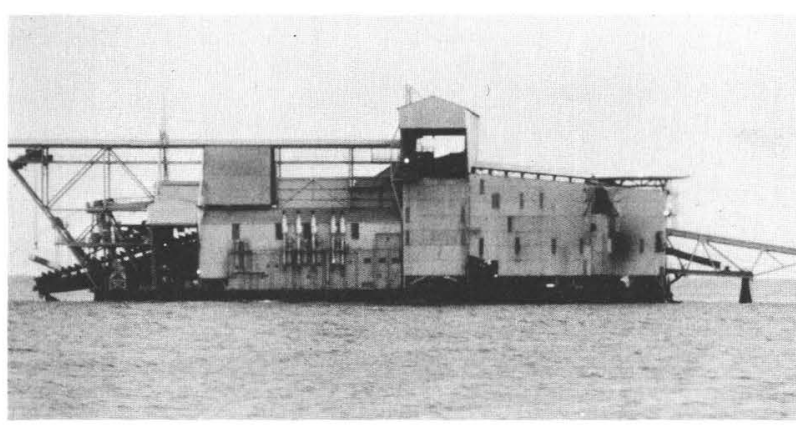

Figure 16.--The Bima, a new offshore gold dredge in the Nome area, is approximately $525 \mathrm{ft}$ long, 140 ft wide, and 14 stories high. Inspiration Gold, Inc., photograph by Laura Kosell.

(Northern Miner, Mar. 17, 1986). Plans called for partial rehabilitation of the mine workings and an evaluation of the remaining reserves. Echo Bay Mines Ltd. made plans to evaluate gold reserves at the Juneau and Treadwell mines near Juneau (Petroleum Information's Alaska Report, Oct. 8, 1986). Discovery Gold Explorations had plans to continue evaluating the Dawson mine on Prince of Wales Island (Alaska Journal of Commerce and Pacific Rim Reporter, Feb. 2, 1987). 


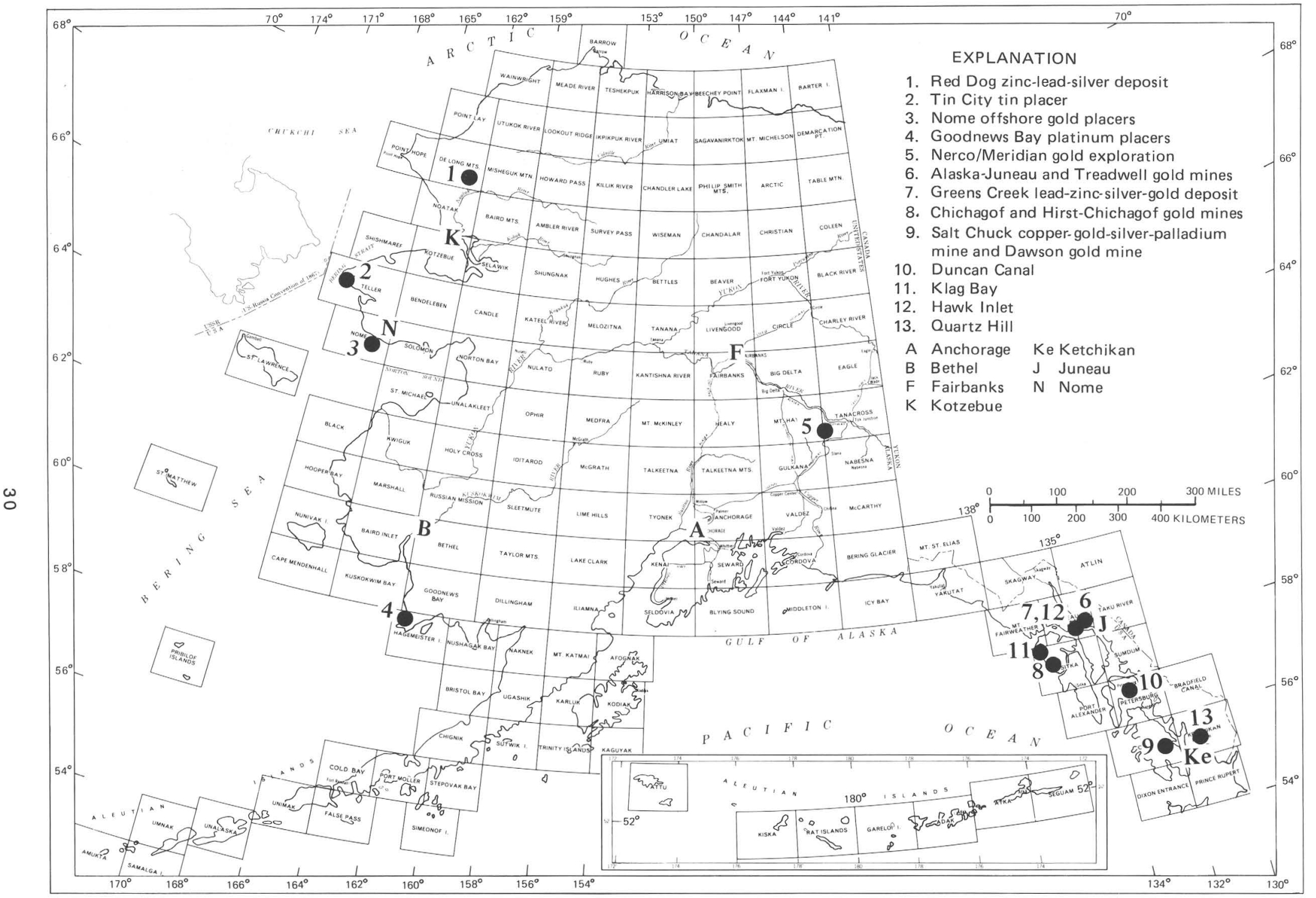

Figure 17.--Areas of significant industry activity for metallic minerals (excluding uranium) in 1986 (locs. 1-9), and mine locations referred to in text (locs. 1, $6,10-13)$. 
In January 1986, the Grant gold mine near Fairbanks was shut down after only 2 months of operation (Petroleum Information's Alaska Report, Jan. 8, 1986) because Aurex, Inc. was disappointed by initial operating results. Aurex, Inc., a subsidiary of Marubeni Corp. of Japan and a major partner in the operation, later withdrew from the project (Petroleum Information's Alaska Report, Jan. 29, 1986).

\section{Strategic and Critical Minerals}

Industry activity in 1986 in strategic and critical minerals was limited to tin and platinum. Tin City Mining Co. continued to mine placer tin at Tin City on the Seward Peninsula (T.K. Bundtzen, oral commun., 1987). Although small amounts of tin are produced at a few gold placer mines, the Tin City mine is the United States' only producing primary tin mine. In 1986, approximately 340,000 ib of tin metal was produced (averaging about 75 weight percent $\mathrm{Sn}$ ), up from the nearly $300,000 \mathrm{lb}$ produced in 1985. Hanson Properties continued to mine placer platinum at Goodnews Bay (fig. 17); production figures are confidential. Fears about the unstable political situation in South Africa generated numerous inquiries about the Goodnews Bay mine, the only significant producer of platinum in the United States (Petroleum Information's Alaska Report, July 23, 1986). The Canadian firms American Platinum, Inc., and Orbex Industries announced plans to examine the Salt Chuck mine, a former producer of copper, gold, silver, and palladium (a platinum-group metal) (Mining Journal, Oct. 31, 1986).

\section{Other Metals}

Zinc and lead prices began to rise slowly in the second half of 1986 , reversing the trends of previous years and providing further economic hope for several major mineral deposits in Alaska. Red Dog, one of the largest undeveloped zinc-lead-silver deposits in the world, continued to move closer to becoming a mine. The deposit, located in northwestern Alaska, has proven reserves of 85 million tons of zinc-lead-silver ore and a projected mine life of 50 years (Mining Engineering, Dec. 1986). The State of Alaska authorized $\$ 175$ million in loans for construction of a port facility to service the mine and for a road from the mine to the port. In March, Cominco Alaska, Inc., Mining Co. and the State reached an agreement on financing and on a loanrepayment schedule for the road (Anchorage Daily News, Mar. 18, 1986); construction of the port facility began in 1986. Request for bids for road construction are to begin during winter 1986-87, with construction to start during winter 1987-88. In November 1986, Cominco officials formally announced plans to develop the deposit; construction of the mine could begin as early as 1987 (Alaska Journal of Commerce and Pacific Rim Reporter, June 16, 1986).
Greens Creek, located on Admiralty Island in southeastern Alaska, is a lead-zinc-silver-gold deposit that also holds great promise of becoming a producing mine. In February 1986, Amselco Minerals, a subsidiary of BP North America, purchased Anaconda Minerals Co.'s share (39.4 percent) of the deposit (Petroleum Information's Alaska Report, Feb. 5, 1986). In May 1986, Amselco purchased Noranda Mining, Inc.'s share of 39.5 percent (Petroleum Information's Alaska Report, May 14, 1986). Road construction at the deposit began in August 1986, but a final decision about developing the property is not expected until early 1987.

For U.S. Borax's Quartz Hill molybdenum deposit, the year was one of waiting. Efforts to obtain necessary permits continued, but molybdenum prices will have to improve before mine construction can begin (Alaska Journal of Commerce and Pacific Rim Reporter, Oct. 27, 1986).

\section{Activity By Pederal Agencies}

\section{U.S. Geological Survey}

Studies of nonfuel minerals in Alaska are an important part of the USGS programs in Alaska. AMRAP continues as a major USGS program for geologic mapping and assessment of the mineral potential of Alaskan lands. AMRAP activities in 1986 were commensurate with the past few years. The TACT program (fig. 18) continues, and many of the data have been gathered for the southern and central parts of the transect.

\section{Alaska Mineral Resource Assessment Program}

AMRAP studies are conducted at four progressively more detailed levels to produce comprehensive assessments of Alaska's mineral and energy resources. Level I studies are statewide in scope; published maps are generally at a scale of $1: 2,500,000$. In 1986 , work continued on maintaining and updating the mineral data base for the entire State of Alaska, including a major compilation of the significant metallic lode deposits and placer districts of Alaska (Nokleberg and others, 1987).

Level Il studies address large parts of the State; resulting maps are generally at a scale of $1: 1,000,000$. Studies related to the metallogenesis of the eastern Alaska Range continued, and the last level 11 study in Alaska, on the geology and mineral resources of the Alaska Peninsula, began in 1986 .

Level III studies continue to receive the major effort of AMRAP (fig. 19), consisting of multidisciplinary evaluations involving team studies of selected $1^{\circ}$ by $3^{\circ}(1: 250,000$ scale) quadrangles. Geologic, geochemical, and geophysical data are gathered to define and assess 


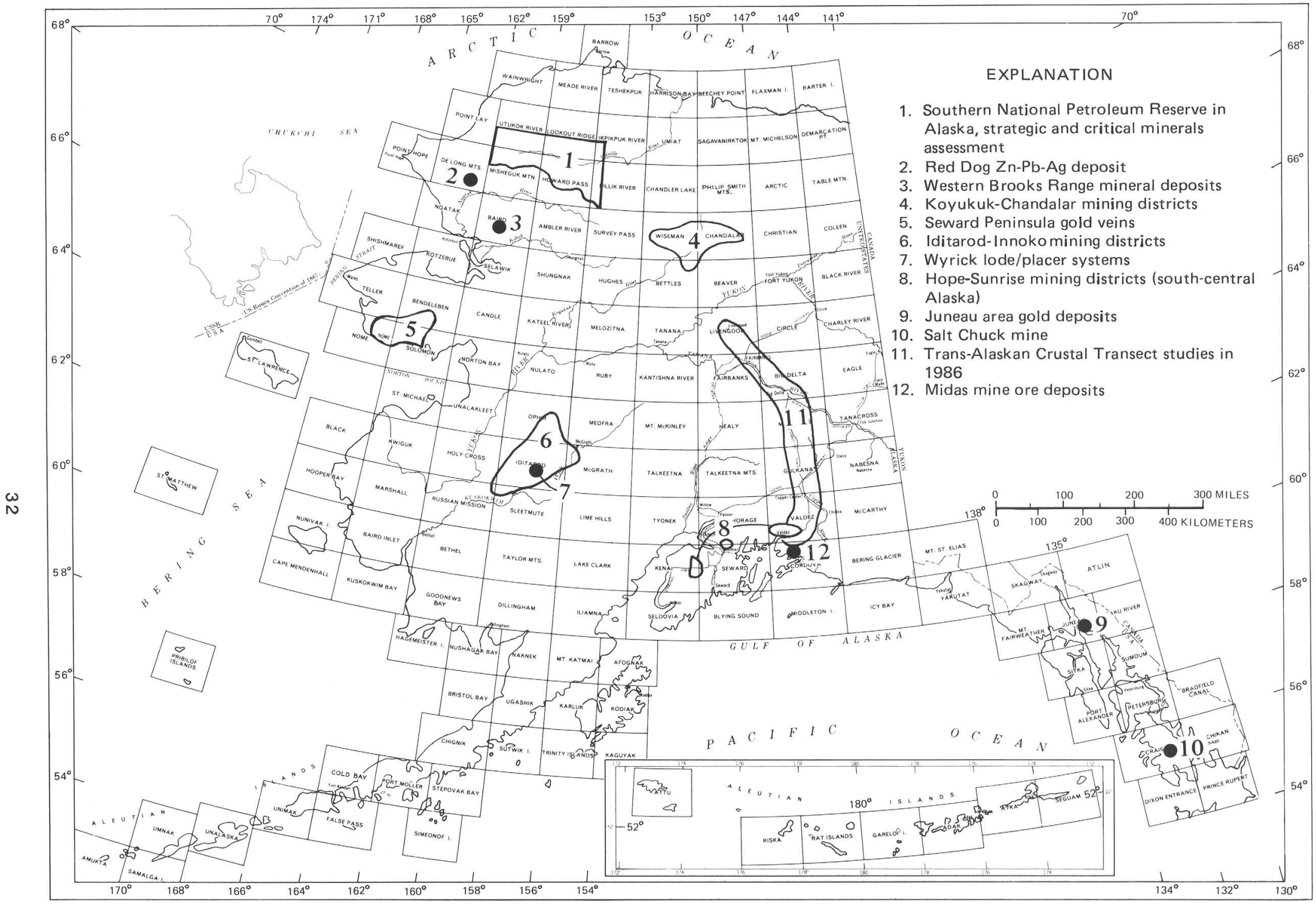

Figure 18.--Locations of U.S. Geological Survey metallic-mineral studies in 1986. 


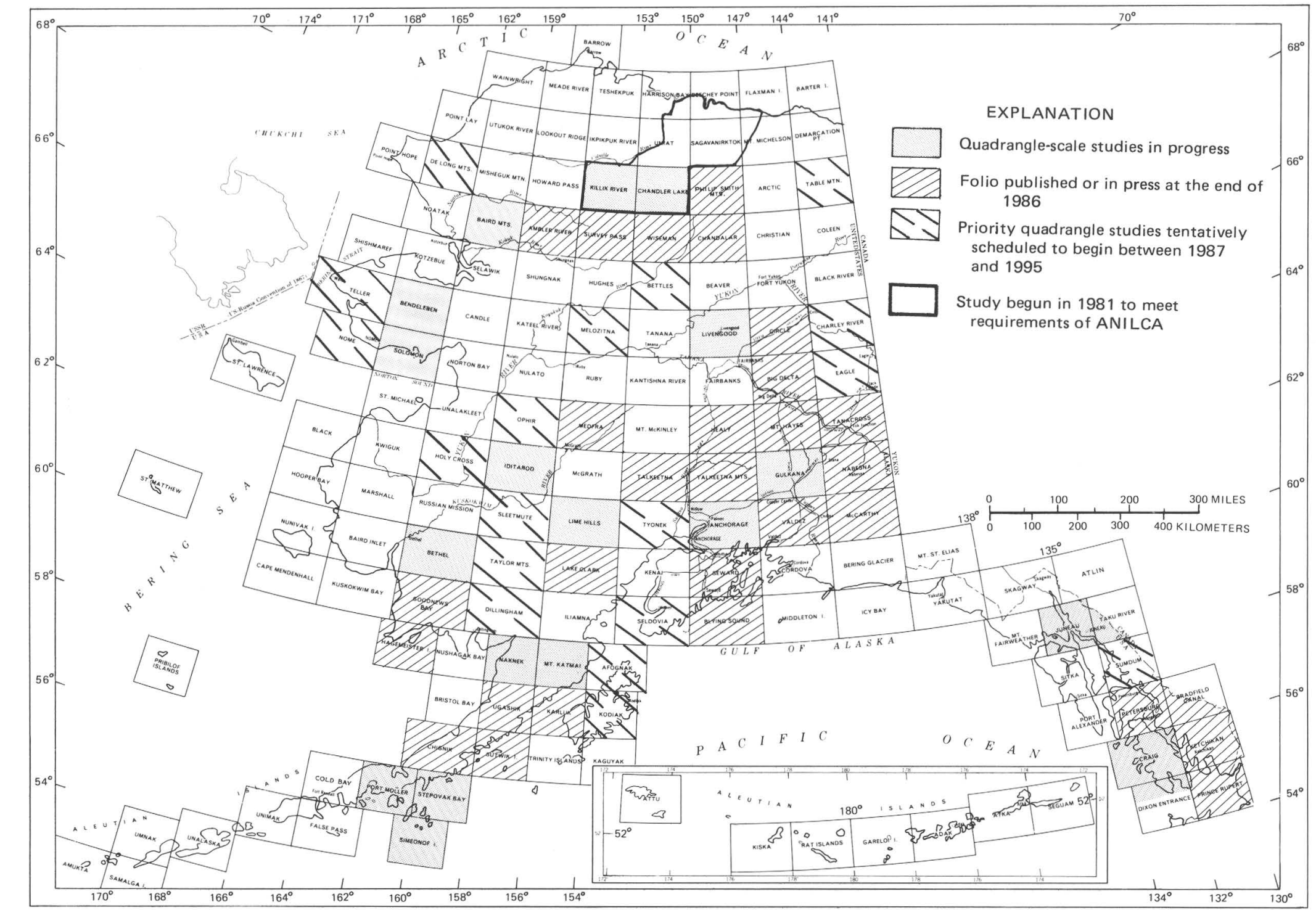

Figure 19.--Status of level III Alaska Mineral Resource Assessment Program quadrangle studies as of February 1987. 
areas of mineral-resource potential for specific types of deposits. Studies are in progress in 20 quadrangles. Fieldwork in the Bendeleben and Solomon quadrangles was completed in 1985; the geologic map and fossil data have been published (Till and others, 1986), and other reports are in preparation. In 1986, fieldwork was completed in the Baird Mountains, Port Moller, Stepovak Bay, Simeonof Islands, Iditarod (a joint project with the ADGGS), Mount Katmai, Naknek, Anchorage, Killik River, and Chandler Lake quadrangles; reports are currently in preparation for these areas. Fieldwork continues in the Livengood, Juneau, Taku River, Craig, Dixon Entrance, and Gulkana quadrangles; studies in Lime Hills and Bethel quadrangles were started in 1986. Most level III AMRAP projects also publish an assessment of the mineral resources of the quadrangle examined.

Level IV studies consist of detailed mapping (at a scale of $1: 63,360$ or larger) of mining districts, specific mineral deposits, and related subjects. The locations of level IV studies are shown in figure 19, and the project titles are listed in table 4.

Some of the reports published in 1986 as a result of AMRAP and related USGS programs include: examination of lode and placer gold deposits in part of the Iditarod quadrangle (fig. 20; Bundtzen and others, 1986); geology of placer deposits in the Iditarod quadrangle (Bundtzen and others, 1986); geology and mineralization at several mineral deposits in the Brooks Range (Folger and Schmidt, 1986; Schmidt and Folger, 1986); rock geochemical data for the Port Moller, Stepovak Bay, and Simeonof Island quadrangles (Angeloni and others, 1986); geologic maps of the Bendeleben and Solomon quadrangles, and the southern part of the Kotzebue quadrangle ('Till and others, 1986); a geologic map of Chugach National Forest (Nelson and others, 1986); a geologic map of the Wiseman quadrangle (Dillon and others, 1986); and analytical data for sediment samples from the Cordova and Middleton Island quadrangles (Sutley and others, 1986). Many other reports resulting from USGS activities in 1986 are in press or in preparation; among those relevant to mineral deposits are: geologic maps and (or) mineral-resource appraisals of the Katmai, Naknek, Baird Mountains, Port Moller, Stepovak Bay, Simeonof Islands, Iditarod, Mount Hayes, Chandler Lake, Bendeleben, and Solomon quadrangles and the southern part of the Kotzebue quadrangle; metallogeny and major mineral deposits of Alaska; and metalliferous lode deposits and placer districts of Alaska.

The third annual Mckelvey Forum, entitled "USGS Mineral Resources Research: Progress and Perspectives, 1987," included several oral and poster presentations on research of mineral deposits in Alaska. The forum was held March 1112, 1987, in Denver, Colo.

Table 4.--Level IV studies of the Alaska Mineral Resource Assessment Program active in 1986

[Figure 18 shows generalized areas under study. Project chiefs are listed in parentheses. Projects marked by an asterisk are of statewide scope. Data modified from Winkler and Grybeck (1986)]

Areal mineral-resource assessments

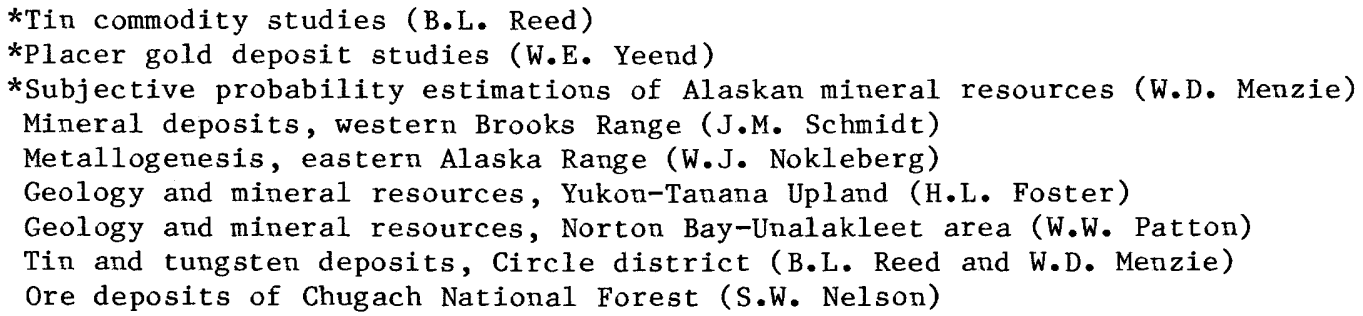

Areal energy-resource assessments

Petroleum potential of the Yukon-Kandik Basin (H.E. Cook) Geologic framework and petroleum potential of the Nenana Basin (R.G. Stanley) Coal studies in the Nenana Basin (C. Wahrhaftig) 
Genesis of trace elements of the Nenana Basin coal fields (G.D. Stricker)

Coal resources of northern Alaska (G.D. Stricker)

Uranium potential of Alaskan basins (K.A. Dickinson)

Exploration geophysical studies

Gravity studies (including Red Dog, Haines, and Red Mountain deposits) (D.J. Barnes) Geophysics of the Yukon-Koyukuk Basin and its borderlands (J.W. Cady)

Mining geophysics of central Alaska (D.L. Campbe11)

Biostratigraphic studies

Brooks Range and Arctic Slope studies (L.N. Marincovich)

*Paleozoic and Mesozoic radiolarians (C.D. Blome and B.L. Murchey)

*Brachiopod and conodont paleogeography (J.T. Dutro and A.G. Harris)

Mesozoic dinoflagellate biostratigraphy, southern Alaska (N. Albert)

Framework or process studies

Yukon-Koyukuk crustal transect study (W.W. Patton)

Structural analysis of interior metamorphic terranes (J.H. Dover)

Mafic and ultramafic rocks of Alaska (R.A. Loney)

Coastal sediments of upper Cook Inlet (S. Bartsch-Winkler)

Upper Mesozoic stratigraphy of the Alaska Peninsula (R.L. Detterman)

Upper Cook Inlet-Nelchina area stratigraphic studies (A. Grantz and T.E. Moore)

* Paleomagnetism of accreted terranes (C.S. Gromme)

*Metamorphic-facies map of Alaska (C. Duse1-Bacon)

Northwestern Alaska crustal study (A.B. Till)

Exploration geochemical studies

Alaska placer gold deposits (J.C. Antweiler)

Southern Alaska lode gold deposits (J.R. Goldfarb)

Geochemistry in glacial areas (E.B. Evenson)

Isotopic and radiometric studies

*K-Ar studies and radiometric-age file (N. Shew)

*Lead and oxygen isotope studies (S.E. Church)

Geochemical characterization of accreted igneous arcs, southern Alaska (F. Barker) 


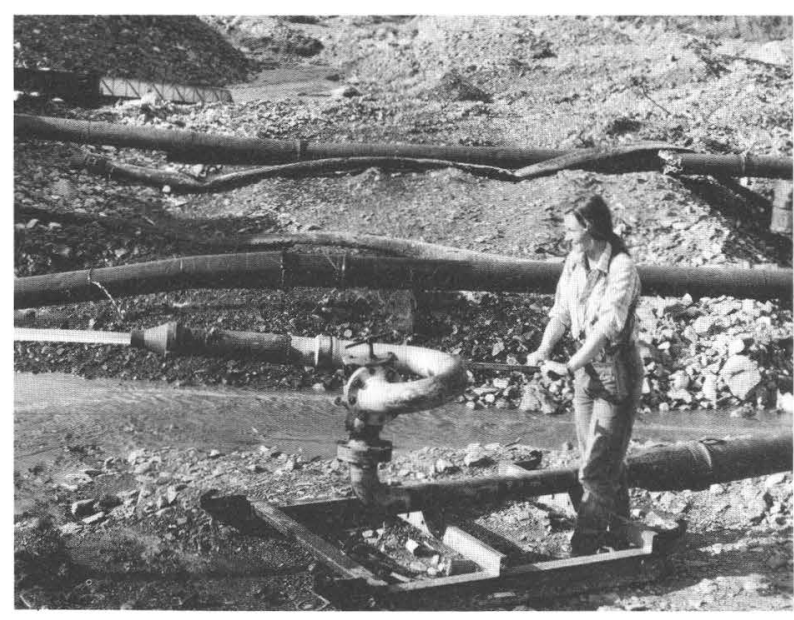

Figure 20.--U.S. Geological Survey geologist examining hydraulic gold-mining operation near Iditarod during mineral-assessment study. Photograph by D.J. Grybeck.

The third year of work on the TACT program was completed on schedule. This program is a major integrated multidisciplinary investigation designed to study the geology, tectonics, and deepcrustal structure of Alaska along a corridor parallel to the Trans-Alaska Pipeline. Fieldwork in 1986 concentrated on deep-crustal seismicrefraction studies in the central section of the transect (fig. 18). Recent reports include a major summary article on the geology, geophysics, and tectonics of southern Alaska (Page and others, 1986), and companion articles about the geology and geophysics of sections of the transect.

\section{Precious Metals}

USGS geologists are involved in several studies of precious-metal occurrences in Alaska. Research underway and reports published in 1986 include those on: gold veins of the Seward Peninsula, gold deposits of the Juneau area (Leach and others, 1986), and gold occurrences in southcentral Alaska (Goldfarb and others, 1986). In 1986 , a report was published on placer gold occurrences in the Koyukuk-Chandalar mining district. Most level III AMRAP studies also involve some aspect of precious-metal deposits.

\section{Strategic and Critical Minerals}

In 1986, the USGS initiated a study of the Salt Chuck copper, gold, silver, and palladium deposit, which also contains minor amounts of platinum. Budget constraints in 1986 prevented continuing a study of tin occurrences on the Seward Peninsula; this study is anticipated to resume in 1987. Also in 1986, a report was published on strategic and critical minerals in the NPRA (Ellersieck and Tailleur, 1986).

\section{Other Metals}

Studies of other types of mineral deposits in Alaska include an examination of mineral deposits in the western Brooks Range, and examination of ore deposits in Chugach National Forest (fig. 21).

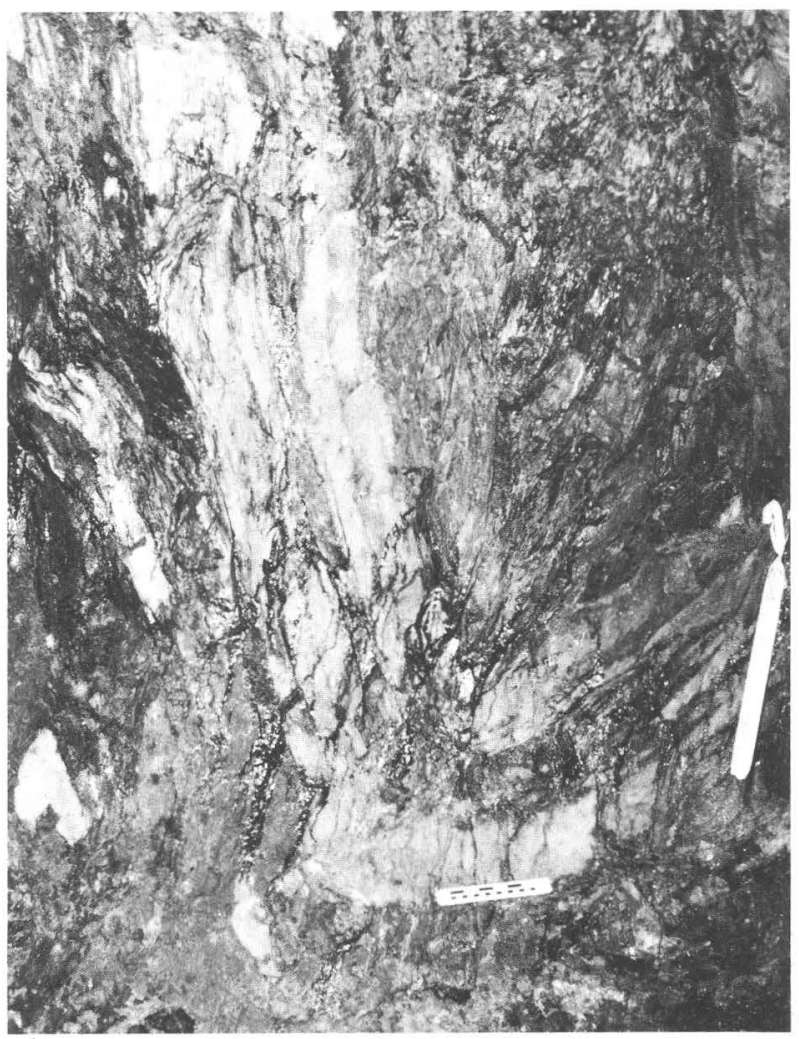

Figure 21.--Interbedded massive sulfide ore (dark layers of chalcopyrite and pyrite) and sandstone (light layers) in main stope of the Midas mine near Valdez. Study is part of U.S. Geological Survey investigation of ore deposits in Chugach National Forest. Photograph by S.W. Nelson.

\section{U.S. Bureau of Mines}

The USBM's AFOC is responsible for conducting four programs under the directorate of Mineral Data Analysis and for coordinating work with other USBM research centers throughout the United States.

\section{Minerals Availability Program}

The Minerals Availability Program is described in appendix 2 of this report. A density plot of mineral locations on the Minerals Availability System (MAS) data base in Alaska is shown in figure 22. In 1986, data for 145 Alaskan proper- 


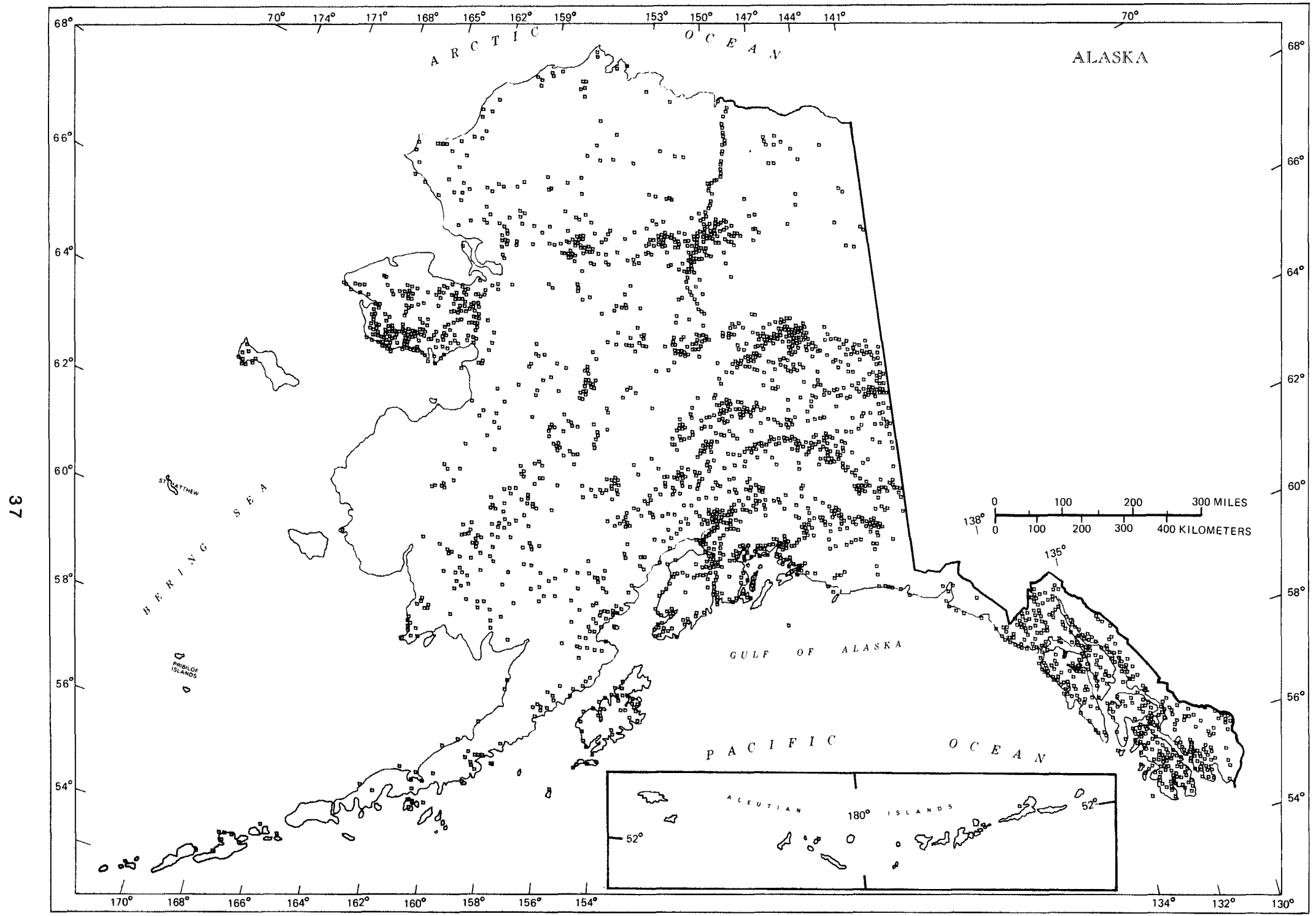

Figure 22.--Locations of minerals on U.S. Bureau of Mines Minerals Availability System computer data base, including known metallic minerals, coal, uranium, and developed quarries of sand and grave1, building stone, jade, and soapstone. Prepared by U.S. Bureau of Mines Alaska Field Operations Center, February $28,1987$. 
ties were entered in its MILS data base (a subset of MAS) as potential mineral producers. An MILS directory for Alaska, listing the names and locations of 281 deposits and detailed information for 67 significant deposits, is in the final editorial process. Minerals Availability Program activities included an economic-feasibility analysis of offshore gold mining in the Nome area, which is to be included in a USBM report to the Minerals Management Service.

Other activities during 1986 included a study of Alaska placer and lode production to predict remaining reserves of past Alaska precious-metal producers, and a study of the feasibility of mining near-shore and offshore mineral deposits of Alaska, initiated in 1986 as part of USBM participation in an Exclusive Economic Zone study.

\section{Minerals Policy and Analysis}

The USBM's Division of Minerals Policy and Analysis centered its attention on the status of land that is available for mineral exploration and development in Alaska versus land that is restricted. Map overlays at 1:250,000 scale showing the categories of land availability for northern, north-central, south-central, and southeastern Alaska have been open-filed in the USBM's Anchorage, Fairbanks, and Juneau offices (Roberts, 1985; Bottge, 1986b, c; Maas, 1987). Reports that include analytical data and landavailability maps at 1:500,000 scale have been published for southeastern, north-central, and south-central Alaska (Roberts, 1985; Bottge, $1986 \mathrm{~b}, \mathrm{c})$. The report on northern Alaska is in press, and a compilation for western and southwestern Alaska is in preparation. A report comparing the cost effectiveness of company towns versus commuting camps in developing Alaska's mineral resources was also published (Bottge, 1986a).

\section{State Mineral Activities}

Reports written under the auspices of the State Mineral Officer include the Alaska chapter in the "Minerals Yearbook, Volume II" and the annual preliminary "Mineral Industry Survey," which details significant mineral activity throughout the State in the preceding year. Periodic updates have been prepared for the "Alaska Mineral Briefing Profile," as have listings of associations and organizations interested in minerals, and of meetings, conferences, and symposia of the mineral industry. The State Mineral Officer continues to participate with the interagency team preparing the EIS for the Quartz Hill molybdenum mine project.

\section{Mineral Land Assessment}

The USBM's fieldwork in the Juneau mining district (loc. A, fig. 23) is part of a 4-year study.
The program will identify the type, amount, and distribution of mineral deposits in the district, determine ore reserves, study beneficiation technologies for the ore, make feasibility studies, and address economic and legislative effects on mineral development. The Juneau study is a cooperative effort involving the USBM and the ADGGS. ADGGS personnel make detailed geologic studies of selected areas, while USBM personnel conduct site-specific examinations.

The Juneau mining district has been subdivided into four areas for evaluation, shown in fig. 23: the Glacier Bay/Mount Fairweather area; the Volcanic area, which includes the West Lynn Canal, Haines, and Porcupine areas; the Juneau Gold Belt; and the Molybdenite area, bordering Canada, north and east of the Juneau Gold Belt.

Work in Glacier Bay is nearing completion. A metallurgic test sample collected from the upper and lower nunataks of the Brady Glacier nickel-copper-cobalt/platinum-group metals deposit is being evaluated for recovery of cobalt and platinum-group metals (PGM).

In the Haines area, a granite porphyry was discovered north of Klukwan that contained copper mineralization. Samples collected from a magnetite-copper-cobalt skarn discovered on the south side of the Tsirku River contain traces of gold. On the basis of sample results and geologic examination, several West Lynn Canal areas were determined to be favorable for hosting significant mineralization.

During July 1986, a USBM erew discovered copper-gold mineralization in a roadeut $3.1 \mathrm{mi}$ south of the city of Haines. Subsequent work on the prospect consisted of trenching, mapping, sampling, and geophysical surveys. Preliminary sample results indicate gold values as high as 0.9 troy oz/ton and copper values as high as 22 weight percent. Geophysical surveys conducted over the roadcut indicate that the mineralized zone extends for at least $1,000 \mathrm{ft}$ along strike and that a smaller mineralized area exists $130 \mathrm{ft}$ east of the roadcut zone.

As part of the USBM-ADGGS cooperative project, approximately $380 \mathrm{~km}^{2}$ in the upper Chilkat and Kelsaw River drainages (Skagway C-3 and C-4 quadrangles) and approximately $260 \mathrm{~km}^{2}$ in the northern Chilkat Mountains (Skagway A-2, $\mathrm{A}-3$, and A-4 quadrangles) were geologically mapped at a scale of 1:40,000, and sampled for mineral content by State geologists.

The USBM and ADGGS completed an evaluation of the placer resources of the Porcupine mining area near Haines during 1986. The USBM sampled and evaluated the placer deposits (fig. 24), and the ADGGS mapped the geology and summarized the glacial geologic history of the area. Three types of placer deposits occur in the area: (1) stream-channel gravels; (2) bench placers; and (3) alluvial fans. Each of these deposit types was sampled to estimate resources, identify gold fineness (a measure of gold purity), 
determine mineral-development-potential ratings for streams, and calculate optimum screening sizes for use in recovery plants. For 13 samples, gold fineness ranged from 669 to 902 and averaged 837; the fineness of pure gold is 1,000. Identified resources include $932,000 \mathrm{yd}^{3}$ of gravel rated at moderate or high mineral-development potential. A report summarizing the results of the study was published by Hoekzema and others (1986).

During the 1986 field season in the Juneau Gold Belt, the USBM located 51 prospects mentioned in various literature sources and reexamined 21 others. Field crews collected about 600 samples and mapped 7,850 ft of underground workings. Metallurgic test samples were collected from the Alaska Juneau mine, the Treadwell Mexican pit No. 1, Nevada Creek, the Ibex, the Peterson, the E Pluribus Unum, and the Jualin. Two USBM open-file reports were released on the Juneau Gold Belt, one on the results of 1985 work (Redman and others, 1986) and one on the historical development of mining in the gold belt (Redman, 1986).

Work in the Molybdenite area (fig. 23) was limited to reconnaissance efforts. Preliminary data analysis indicates that although molybdenum is widespread, concentrations are very rare. However, the data indicate that areas in Boundary Creek and the north fork of the Speel River are worthy of a followup investigation, and several adjacent areas of metamorphic rock may contain significant concentrations of base or precious metals. State geologists reconnaissance-mapped and geochemically sampled approximately $850 \mathrm{~km}$ of the northern part of the Molybdenite area (Skagway C-1, C-2, C-3, and D-2 quadrangles).

Fieldwork for the Chugach National Forest Roadless Area Review and Evaluation (RARE) II study was completed in 1982. USBM reports published in 1986 evaluating placer and lode gold deposits in and near Chugach National Forest are described below.

Information Circular 9091 (Hoekzema and Fechner, 1986) summarizes the USBM placer goid studies in Chugach National Forest. Five types of placer gold deposits were identified: alluvial, bench, eluvial, glacial, and marine. Placer mining from the mid-1890's through 1982 produced an estimated 133,800 troy oz of gold, of which twothirds was produced before 1920. As much as 6,800 troy oz of placer gold was produced from 1979 to 1982; most production came from Crow, Canyon, and Resurrection Creeks.

Placer sampling indicated a potential for gold production from alluvial and bench placers associated with historically mined drainages, such as Crow, Canyon, Resurrection, Sixmile, and Mills Creeks, and from unmined drainages, including the Avery, Kings, Snow, Copper, and Tasnuna Rivers and several smaller streams throughout Chugach National Forest. Results of tests indicated that gold from Chugach National Forest ranges in fineness from 455 to 950 . Subsequent investiga- tions in drainages with anomalous placer-sample values also identified previously unknown lode mineralizaton.

Information Circular 9113 (Hoekzema and others, 1986) describes the history, characteristics, distribution, and mineral-development potential of 21 lode gold deposits in or near Chugach National Forest. The report includes findings from a 4-year (1979-82) mineral evaluation conducted by the USBM and the USGS. This evaluation, undertaken to provide the USFS with mineral-resource data for decisionmaking on land use, included sitespecific mapping and sampling of more than 200 lode gold deposits. Of the 21 lode gold deposits described in Information Circular 9113, 14 contain a combined identified resource of 117,750 tons averaging 0.55 troy oz Au/ton and 0.2 troy $\mathrm{oz}$ $\mathrm{Ag} /$ ton. Two mineralized felsic dikes in the Summit Lake-Palmer Creek area contain a combined identified resource of 18 million tons grading 0.02 troy oz $\mathrm{Au} /$ ton and 0.16 troy oz $\mathrm{Ag} /$ ton. Identified resources were not determined for the remaining five deposits because of an absence of information.

Open-File Report 50-86 (Meyer, 1986) summarizes investigations of lode and placer deposits in the Valdez Creek mining district east of Cantwell. Three significant mineralized areas were delineated: the Chulitna River-Broad Pass area, the Clearwater Mountains area, and the Maclaren River and Glacier.

An evaluation of the mineral-development potential of onshore platinum and gold resources in the Goodnews mining district was completed in 1986. Preliminary results from the samples collected indicate that minor precious-metal resources exist along the beaches between Chagvan and Goodnews Bays, drainages in the Red Mountain area contain significant placer platinum values, and two drainages in the Wattamuse area have significant mineral development potential for placer gold. Float samples collected from the Upper Wattamuse Creek area contained as much as 2 troy oz Au/ton. Bulk samples collected from the top of Red Mountain show a source of both platinum and gold for the Salmon River placer deposits.

Additional reports summarizing USBM reconnaissance in the Yentna and Willow Creek mining districts were completed (Fechner, 1986; Kurtak, 1986).

\section{Critical and Strategic Minerals}

As part of the studies mandated by ANILCA, the USBM is evaluating occurrences of strategic and critical minerals. Project work in 1986 was divided between studies of tin-tantalumcolumbium and chromium-cobalt-PGM. The results of USBM chromite investigations in Alaska were summarized by Foley and others (1986). Locations of the 1986 USBM project work are shown in figure 23 and listed in table 5. Deposits 


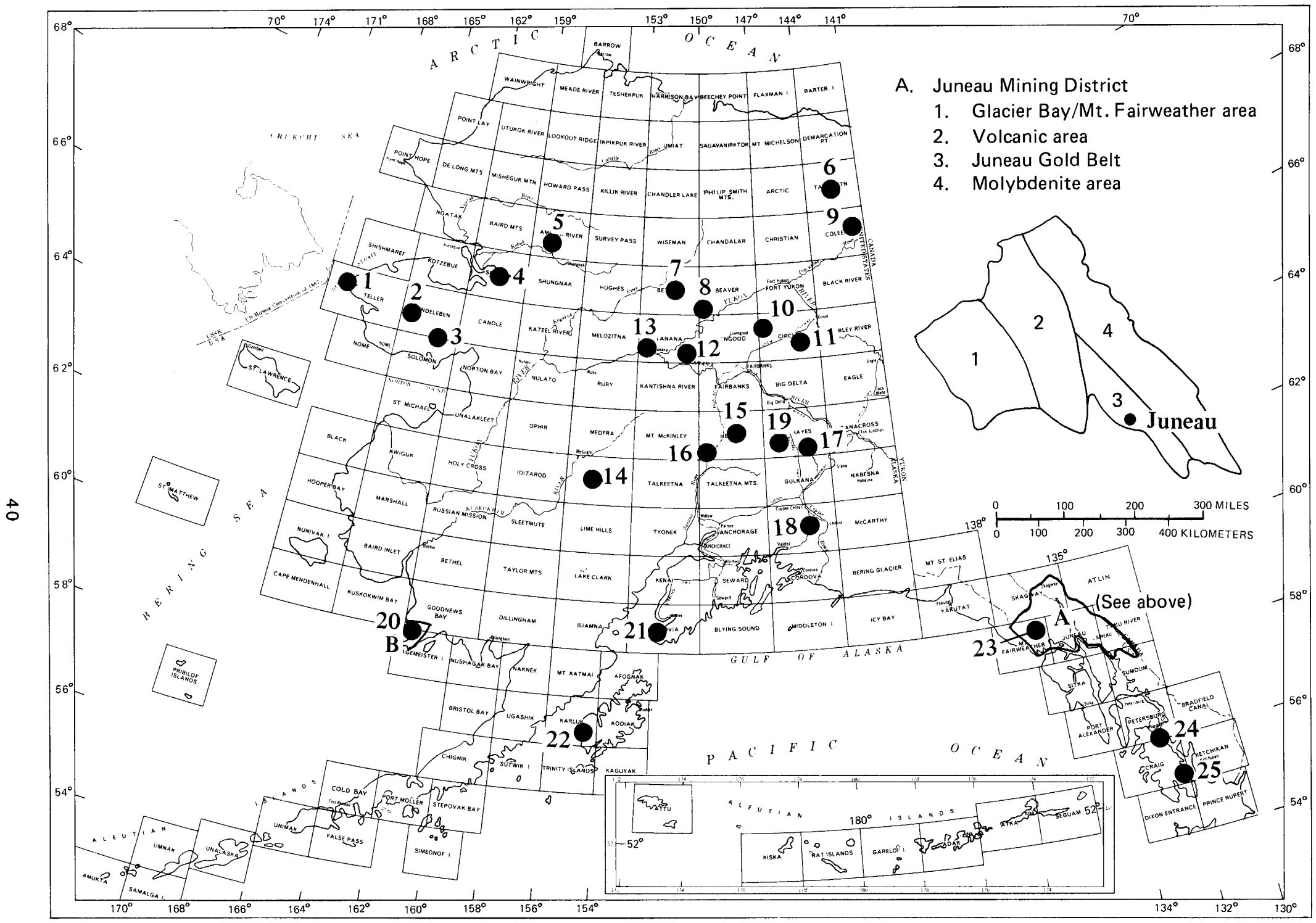

Figure 23.--Locations of U.S. Bureau of Mines 1986 mining-district studies (A, B) and 1986 studies of critical and strategic minerals (1-25) listed in table 5 . 
Table 5.--Areas of U.S. Bureau of Mines activity in mining districts and critical and strategic minerals in 1986

[See figure 23 for locations. PGM, platinum-group metals; REE, rare-earth element]

$\begin{array}{ll}\text { Mining district area } & \text { Deposit of major interest } \\ \text { A. Juneau } & \text { A. } \begin{array}{c}\text { Lode gold, volcanogenic massive sulfide, } \\ \text { sediment-hosted massive sulfide, } \\ \text { molybdenum porphyry, placer gold. }\end{array} \\ \text { B. Goodnews Bay } & \text { B. Placer gold and platinum }\end{array}$

Area of critical and strategic minerals

Element or mineral of interest

\begin{tabular}{|c|c|}
\hline 1. & $\begin{array}{l}\text { Cape Prince of Wales, } \\
\text { Cape Mountain. }\end{array}$ \\
\hline 2 . & Koug arok \\
\hline 3. & Selawik Hills \\
\hline 4. & Darby Mountains \\
\hline 5. & Bornite \\
\hline 6. & Bear Mountain \\
\hline 7. & Kanuti region \\
\hline 8. & Fort Hamlin $\mathrm{Hills}$ \\
\hline 9. & old Crow Hills \\
\hline 10. & Lime Peak (Rocky Mtn.) \\
\hline 11. & Ketchum Creek \\
\hline 12 . & Tofty \\
\hline 13. & Tozimoran Creek \\
\hline 14. & Kuskokwim \\
\hline 15. & Sheep Creek \\
\hline 16. & Chultina area \\
\hline 17. & Rainbow Mountain \\
\hline 18. & Tonsina \\
\hline 19. & MacClaren \\
\hline 20. & Goodnews Bay area \\
\hline 21 . & Red Mountain \\
\hline 22 . & Halibut Bay \\
\hline 23. & Brady Glacier \\
\hline 24. & Salmon Bay \\
\hline 25 . & Bokan Mountain \\
\hline
\end{tabular}

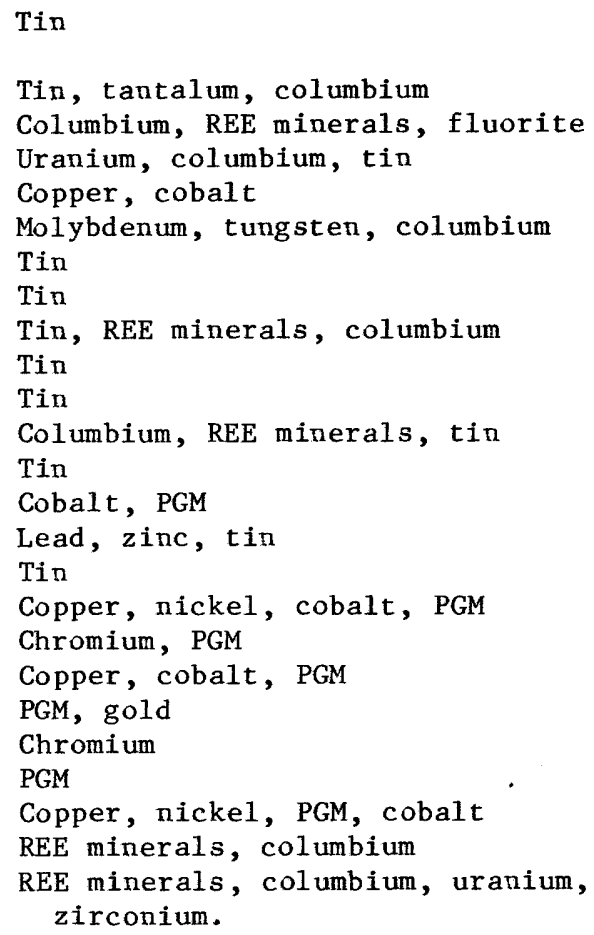

of columbium and rare-earth elements (REE's) on Prince of Wales Island were mapped and sampled in detail. Mapping, geophysical surveys, and sampling were continued in the areas of PGMbearing marine placers near Goodnews Bay, and of lode and placer tin occurrences in the Fort Hamlin Hills (loc. 8, fig. 23). Limited diamond drilling was utilized to further evaluate the chromite-PGM occurrences near Tonsina, where large but lowgrade zones of disseminated and stringer chromite occur.

Reconnaissance field studies were conducted for tin, REE's, and columbium in the Old Crow Hills (loc. 9, fig. 23), and for cobalt and PGM in the Kuskokwim and MacClaren areas (locs. 14 and 19, fig. 23). Further work is planned for these areas in 1987.

Data compilation and laboratory studies were in progress during 1986 for marine tin placers at Cape Prince of Wales, a tin placer at Tozimoran, a PGM occurrence on Kodiak Island, and columbium-REE occurrences in both the Selawik Hills and Salmon Bay (fig. 23). Efforts to develop a cobalt-recovery technique for copper ore from the Bornite deposit are under way at the USBM's Albany, Oreg., Research Center. Similarly, the Albany Research Center worked on tin recovery from the deposits at Ketchum Creek, 


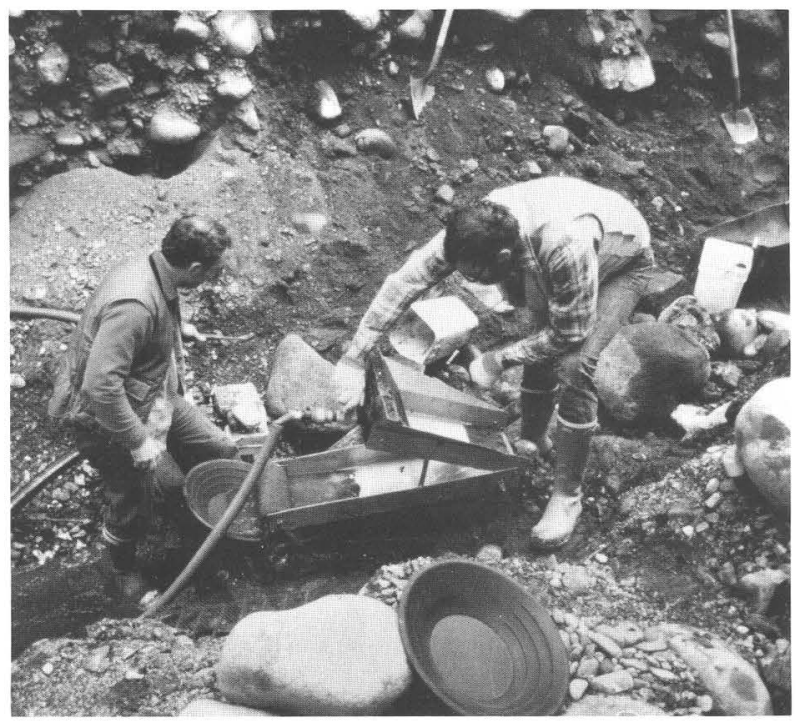

Figure 24.--U.S. Bureau of Mines' geologists sampling placer gold on Porcupine Creek in the Juneau mining district. Photograph by M.P. Meyer.

Sheep Creek, and Chultina (fig. 23).

Ore dressing and beneficiation testing at the USBM's Salt Lake City, Utah, Research Center are in progress on ores from the Kougarok tintantalum deposit, the Red Mountain chromite deposits, the copper-nickel-cobalt-PGM occurrences near Rainbow Mountain and Brady Glacier, and the columbium-REE prospects on Prince of Wales Island (fig. 23).

Several reports of strategic- and criticalmineral investigations were published in 1986. The results of tin placer and lode studies in the Kanuti area indicate reserve potential associated with the Sithylimenkat pluton in central Alaska (Barker and Foley, 1986). Examination of the lode PGM potential of the Goodnews Bay ultramafic body found PGM to be widely disseminated in the ultramafic host (Southworth and Foley, 1986). Columbium and REE minerals are prevalent in gold placers at Tofty; the report by Warner and others (1986) describes the carbonate sources of these minerals. Uranium vein occurrences in the Darby Mountains on the Seward Peninsula are associated with a regional anomaly of columbium in placer concentrates (Foley and Barker, 1986). Chromium investigations in Alaska and the results of metallurgic characterization are described in the proceedings of the chromium conference held in Corvallis, Oreg. (Daellenbach, 1986). The USBM has determined that low-grade Alaskan chromite deposits are adequate to meet U.S. consumption for at least 6 years. Tungsten-molybdenum porphyry mineralization at Bear Mountain in the ANWR was found to contain byproduct levels of columbium (Barker and Swainbank, 1986).
Placer Mining Effluents

During 1986, the USBM Tuscaloosa Ala., Research Center conducted field-test operations to clarify Alaskan placer-mining effluents at four sites in Alaska: Crooked Creek in the Circle mining district, Fairbanks Creek in the Fairbanks mining district, Olive Creek in the Livengood mining district, and Resurrection Creek in the Hope mining district. The results of this testing program were positive and indicated that the claydewatering technique using the flocculant polyethylene oxide (PEO) may be a means of mining some placer deposits within the framework of current regulation.

\section{Bureau of Land Management}

The BLM issued one mineral patent in 1986 for 21 placer gold claims. A total of 351.423 acres was conveyed for these claims in the Rampart area northwest of Fairbanks. The oil and gas section of this circular discusses the effect of the National Wildlife Federation v. Burford et al. lawsuit on mining-claim activity.

On February 18, 1986, a coalition of environmental and Native groups filed a lawsuit against the BLM over various National Environmental Policy Act (NEPA) issues. The group asked that all mining on BLM lands be halted until the BLM conducted an environmental assessment of each mining operation. The order would have closed operations at an estimated 242 mines, but an outof-court settlement on the temporary restraining order was reached in April, before the mining season began. In February 1987, a Federal judge ruled that the BLM is not required to perform either an NEPA analysis or a subsistence evaluation pursuant to Section 810 of ANILCA on placer operations that disturb 5 acres or less.

\section{Fish and Wildife Service}

In keeping with its primary mission, efforts of the FWS relating to mineral activity emphasize fish, wildlife, and habitat protection. However, some mining claims were located before refuges were established. According to BLM records, as of December 1986, there were 14 active patented placer mines, 107 active placer mines, 153 active lode mines, two millsites, and one mineral-survey application in 12 of Alaska's 16 national wildlife refuges. Most of the placer mines were in the Togiak and Yukon Delta National Wildlife Refuges, and most of the lode mines were in the Alaska Peninsula and Innoko National Wildlife Refuges (fig. 2).

The FWS is working to convince the U.S. Army Corps of Engineers and the Environmental Protection Agency to regulate placer mining under the Clean Water Act. Presently, these activities are not fully regulated in compliance with the act, and the FWS is concerned that impacts on $\mathrm{fish}$ and 
wildlife are not being adequately considered and mitigated.

Water and fish have been sampled in streams downstream from placer mines, as well as at control areas in the Kanuti and Innoko National Wildlife Refuges, and water has been sampled in the Nowitna National Wildlife Refuge. The analysis of those samples for heavy metals and arsenic was completed by the FWS's Patuxent Wildlife Research Center in 1986, and the FWS is currently reviewing those data.

The FWS initiated a study on bald eagles and heavy metals relative to the U.S. Borax Quartz Hill mine in southeastern Alaska; the study is premine development, to obtain baseline information. The FWS is coordinating with Greens Creek Mining, Inc., relative to environmental concerns with their Hawk Inlet Admiralty Island development of a mine for lead, zinc, copper, gold, and silver. Probable reopening of several old mines in southeastern Alaska was the impetus for additional environmental coordination and baseline sampling activities in 1986, including sampling of sediment and biota for heavy metals at Klag Bay on Chichagof Island. Discussions are ongoing about reopening the Chichagof gold mine by mining the tailings in the bay, a productive marine system. Sampling for heavy-metal concentrations and environmental coordination were also undertaken at the old gold mine in Duncan Canal on Kupreanof Island. There has been some coordination with BP Alaska Exploration, Inc., relative to their reopening of the original Juneau gold mine.

The final EIS for Cominco's world-class Red Dog mine north of Kotzebue was completed in 1986; permits for road and dock facilities were obtained, and construction began. The FWS commented on those permit applications and has initiated followup monitoring to ensure compliance with environmental stipulations.

\section{National Park Service}

The NPS has augmented its mineralsmanagement staff in Alaska to ensure that the program protects park resources consistent with law, regulation, and policy. A Minerals Management Division has been established in the Alaska Regional Office, comprising the Resource Assessment and Mining and Minerals branches. These branches review and analyze mining plans of operations, gather and analyze natural, cultural, and physical engineering information on claim areas; conduct claim-validity examinations; and develop and implement a long-term reclamation program. In addition to the Regional Office, Denali National Park and Preserve and WrangellSt. Elias National Park and Preserve have added mining engineers and environmental specialists to their staffs to implement park-specific aspects of the minerals-management program. Major NPS accomplishments during 1986 were:

1. Program authorization, hiring and orientation of staff, development of policy and procedures, and implementation of programs.

2. Processing and completeness review for $\mathbf{1 8}$ plans of operations for mining activities in five different park units; five plans were determined to be complete, and three received approval by the end of the calendar year.

3. Mineral examinations for claim-validity determinations were completed on 34 lode claims and 38 placer claims.

4. Field investigations were completed for engineering and environmental analyses on the five plans of operations.

5. Photopaneling and surveying of 361 claims in 83 claim groups in five park units was completed.

6. Color infrared and black-and-white aerial photographs were taken of all major claim areas in Denali and Wrangell-St. Elias National Parks and Preserves and in YukonCharley Rivers National Preserve.

7. A multiyear program was implemented for inventory of cultural resources on all mining claims and potential mining-access routes. Approximately one-third of these areas were surveyed in 1986. More than 100 culturalresource sites have been identified thus far.

On May 9, 1985, the Department of the Interior was sued by the Northern Alaska Environmental Center et al., over noncompliance with NPS regulations of mineral operations in Alaska. On July 22, 1985, the Federal District Court issued a preliminary injunction suspending approval of all existing operations effective at the end of the 1985 season, and required the NPS to prepare cumulative EIS's for the mining operations in Wrangell-St. Elias National Park and Preserve and in Yukon-Charley Rivers National Preserve.

The Government filed a motion for reconsideration, which was denied by the court on December 4, 1985. In a memorandum and order, the preliminary injunction was amended to include the requirement of an additional cumulative EIS for the mining operations in Denali National Park and Preserve. However, the court provided for NPS action on plans of operations within the three units requiring EIS's if no cumulative environmental impacts were to occur. The court also invalidated clauses in the NPS mining regulations (36 CFR 9A) that provided for temporary approval of plans of operations, and the automatic-approval provision, should NPS fail to act within 90 days.

In concert with the EIS's, Minerals Management Plans are also being prepared for these park units. These plans will provide policy and offer park-specific guidance for implementing the recommendations of the proposed action in the respective EIS's. To date, the NPS has initiated public and agency scoping, conducted field investigations, and is building a geographic-informationsystem data base to assist with EIS preparation. 


\section{U.S. Forest Service}

One of the largest mining developments in southeastern Alaska, Greens Creek, is in Admiralty Island National Monument, which is administered by Tongass National Forest. Ownership of the mine recently changed; AMSELCO Minerals, Inc. acquired a controlling interest in the deposit. AMSELCO is aggressively pursuing development of the mine. Construction of an access road from tidewater to the mine site is nearing completion and the construction of a second adit, to be used for ore haulage, has begun. AMSELCO intends to be producing concentrate by September of 1988. The Forest Service completed an EIS for the Greens Creek project in January 1983.

U.S. Borax and Chemical Corp.'s Quartz Hill molybdenum deposit is in Misty Fiords National Monument, on a 152,000 -acre tract that is excluded from designation as wilderness. The USFS was the lead agency for the draft EIS released in 1984; a revision became necessary when U.S. Borax provided additional information about marine tailings disposal. The revised draft is scheduled for release in 1987, and the final EIS will follow.

The USFS is preparing to update mineralsrelated data for revision of the Tongass Land Management Plan, scheduled for completion in 1989 and covering the national forest area in southeastern Alaska. Mineral-resource data, including areas of mineral interest, claim staking and exploration activity, and field investigations (such as the USGS' AMRAP), will be used to update the existing data base. This information will, in turn, be used to determine the areas of Tongass National Forest where mineral exploration and development are most likely to occur and to integrate minerals-related activities into the landmanagement process.

\section{INDUSTRIAL MINERALS}

Sand and gravel production, valued at $\$ 75.8$ million, was second only to petroleum production in Alaska's mineral economy for 1986. Production fell by 26 percent from 1985 , owing to the decline of oil-and-gas-related developments on the North Slope and the reduction in urban construction (Bundtzen and Green, 1987).

Building stone ranked fifth in importance to the value of Alaska's mineral industry during 1986 , an increase of 68 percent over the previous year (Bundtzen and Green, 1987). The greatest use of building stone occurred at three construction projects: the Nome seawall, the harbor in the Pribilof Islands, and the Bradley Lake damsite east of Homer.

\section{Activity By Federal Agencies}

\section{Bureau of Land Management}

The disposal of mineral materials (sand and gravel) is currently not a large activity for the BLM, partly owing to the remoteness of BLMadministered lands. Most of the land near transportation systems has been conveyed to the State of Alaska or to Regional Native Corporations. A total of 38 gravel permits were issued in 1986 , mostly related to operation and maintenance of the Trans-Alaska Pipeline north of the Yukon River.

\section{Fish and Wildlife Service}

Agreement was reached in 1986 between the FWS and the Salamatof Native Association, Inc., for an exchange within the Kenai National Wildlife Refuge. Under this exchange, the FWS will obtain a nondevelopment easement for approximately 36 acres in a 50 - to $100-\mathrm{ft}$-wide strip on Native lands on either side of the Kenai River. In exchange, the FWS will make available subsurface rights to sand and gravel on approximately 2,423 acres of the Salamatof Native Association's surface holdings within the Kenai National Wildlife Refuge boundary. The FWS provided extensive input to Arctic Slope Consulting Engineers (ASCE) relative to their gravel-mine proposal on Kaktovik Inupiat Corp. lands adjacent to the ANWR 1002 area, under terms of the August 9, 1983, exchange agreement between the United States of America and the Arctic Slope Regional Corp. The ASCE proposal also involved application for a Clean Water Act, Section 404, permit from the U.S. Army Corps of Engineers. During the negotiations preparatory to final approval of their plan, ASCE agreed to reduce the size of their pit from 2.5 to 1.8 million $\mathrm{yd}^{3}$, so that they do not disturb the valuable lake-basin/wetlands complex in the area. They also agreed to site reclamation requirements and several other mitigating measures requested by the FWS.

\section{U.S. Forest Service}

Annually, the USFS permits the removal of many thousands of tons of sand, gravel, and stone. The bulk of this material, in the form of quarried stone, is used in Tongass National Forest for the construction of timber-sale roads. Lesser amounts are used by State and local governments for the construction and maintenance of breakwaters, airports, and roads.

Chugach National Forest contains sizable deposits of sand and gravel. The Alaska Railroad has permits to use some of this material. A volume of $720,000 \mathrm{yd}^{3}$ has been sold in the Placer River area, for rail-haul sand and gravel intended for use in the Anchorage metropolitan area. 


\section{REFERENCES CITED}

Acevedo, William, Walker, Donald, Gaydos, Leonard, and Wray, James, 1982, Vegetation and land cover, Arctic National Wildlife Refuge coastal plain, Alaska: U.S. Geological Survey Miscellaneous Investigations 1-1443, scale 1:250,000.

Alaska Division of Geological and Geophysical Surveys, 1986, Oil and gas resources of Alaska: Information Circular 31, 9 p. [available from Alaska Department of Natural Resources, 400 Willoughby Center, Pouch M, Juneau, AK 99811].

Alaska Journal of Commerce and Pacific Rim Reporter, 715 L Street, Anchorage, AK 99501.

Alaska Oil and Gas Conservation Commission, 1987, 1986 statistical report: [available from State of Alaska Oil and Gas Conservation Commission, 3001 Porcupine Drive, Anchorage, AK 99501].

Anchorage Daily News [published daily by Anchorage Daily News, Inc., 1001 Northway Dr., Anchorage, AK 99508].

Angeloni, L.M., Wilson, F.H., and Sutley, Stephen, 1986, Map and tables showing preliminary rock geochemical data from Port Moller, Stepovak Bay, and Simeonof Island quadrangles, Alaska: U.S. Geological Survey Open-File Report 85-470, 180 p., scale 1:250,000.

Bader, J.W., and Bird, K.J., 1986, Geologic map of the Demarcation Point, Mount Michelson quadrangle, northeastern Alaska: U.S. Geological Survey Miscellaneous Investigations Map I-1791, scale $1: 250,000$.

Barker, J.C., and Foley, J.Y., 1986, Tin reconnaissance of the Kanuti and Hodzana rivers uplands, central Alaska: U.S. Bureau of Mines Information Circular $9104,27 \mathrm{p}$.

Barker, J.C., and Swainbank, R.C., 1986, A tungstenrich porphyry molybdenum occurrence at Bear Mountain, northeast Alaska: Economic Geology, v. 81 , no. 7 , p. 171-177.

Bird, K.J., and Magoon, L.B., eds., 1987, Petroleum geology of the northern part of the Arctic National Wildlife Refuge, northeastern Alaska: U.S. Geological Survey Bulletin 1778, 711 p.

Bottge, R.G., 1986a, Company towns versus company camps in developing Alaska's mineral resources: U.S. Bureau of Mines Information Circular 9107,19 p.

-1986b, Maps summarizing land availability for mineral exploration and development in northcentral Alaska: U.S. Bureau of Mines OpenFile Report 70-86, 14 quadrangle overlays, scale $1: 250,000$, and U.S. Bureau of Mines Special Report, scale $1: 500,000$.

1986c, Maps summarizing land availability for mineral exploration and development in southcentral Alaska: U.S. Bureau of Mines OpenFile Report 71-86, 21 quadrangle overlays, scale $1: 250,000$, and U.S. Bureau of Mines Special Report, scale $1: 500,000$.

Bundtzen, T.K., and Green, C.B., 1987, Alaska's mineral industry, 1986: Executive summary: Alaska Division of Geological and Geophysical Surveys Public Data File Report 87-2, 4 p.

Bundtzen, T.K., Miller, M.L., and Laird, G.M., 1986, Prospect examination of the Wyrick placer/lode system, Granite Creek, Iditarod-George mining district, Iditarod B-2 quadrangle, Alaska: Alaska Division of Geological and Geophysical Surveys Public Data File 86-29, 10 p.
Carter, L.D., Ferrians, O.J., Jr., and Galloway, J.P., 1986, Engineering-geologic maps of northern Alaska coastal plain and foothills of the Arctic National Wildlife Refuge: U.S Geological Survey Open-File Report 86-0334, 9 p., scale 1:250,000.

Carter, L.M.H., ed., 1986, USGS research on energy resources--1986: Program and abstracts: U.S. Geological Survey Circular 974, 84 p.

Clough, N.K., Patton, P.C., and Christiansen, A.C., eds., 1987, Arctic National Wildlife Refuge, Alaska, coastal plain resource assessment-Report and recommendation to the Congress of the United States and final legislative environmental impact statement: Washington, U.S. Fish and Wildlife Service, U.S. Geological Survey, and U.S. Bureau of Land Management, $2 \mathrm{v}$.

Collett, T.S., Bird, K.J., and Kvenvolden, K.A., 1986a, The effect of freezing-point depression on ice bearing permafrost, North Slope, Alaska [abs.]: American Geophysical Union Annual Meeting, San Francisco, 1986 Proceedings, p. 236.

Collett, T.S., Bird, K.J., Magoon, L.B., Kvenvolden, K.A., and Claypool, G.E., 1986b, Gas hydrates, North Slope Alaska [abs.], in Carter, L.M.H., ed., USGS research on energy resources---1986: Program and abstracts: U.S. Geological Survey Circular 974, p. 11-12.

Cook, H.E., Magoon, L.B., Stanley, R.G., and Casas, Arturo, 1987, Carbonate submarine fans and aprons in frontier petroleum region--Carboniferous Calico Bluff formation, east-central Alaska [abs.]: American Association of Petroleum Geologists Bulletin, v. 71, no. 5, p. 542.

Csejtey, Bela, Jr., Mullen, M.W., Cox, D.P., Gilbert, W.G., Yeend, W.E., Smith, T.E., Wahrhaftig, Clyde, Craddock, Campbell, Brewer, W.M., Sherwood, K.W., Hickman, R.G., Stricker, G.D., St. Aubin, D.R., and Goertz, D.J., III, 1986, Geology and geochronology of the Healy Quadrangle, Alaska: U.S. Geological Survey Open-File 86-396, 92 p.

Daellenbach, C.B., compiler, Chromium-chromite: Bureau of Mines assessment and research: U.S. Bureau of Mines Information Circular 9087, 141 p.

Dillon, J.T., Brosge, W.P., and Dutro, J.T., 1986, Generalized geologic map of the Wiseman quadrangle, Alaska: U.S. Geological Survey OpenFile Report 86-219, scale 1:250,000.

Elison, G.W., Rappoport, A.G., and Reid, G.M., 1986, Report of the caribou impact analysis workshop, Arctic National Wildlife Refuge, November 19-20, 1985: Fairbanks, Alaska, U.S. Fish and Wildlife Service, $39 \mathrm{p}$.

Ellersieck, Inyo, and Tailleur, I.L., 1986, The strategic and critical mineral resources of the southern part of the National Petroleum Reserve in Alaska: U.S. Geological Survey Open-File Report 86-0158, 12 p.

Fechner, S.A., 1986, 1984 sample results for Bureau of Mines site specific mineral investigations within the Yentna mining district, Alaska: U.S. Bureau of Mines Open-File Report 28-86, 53 p.

Foley, J.Y., and Barker, J.C., 1986, Uranium occurrences on the northern Darby Mountains: U.S. Bureau of Mines Information Circular 9103, 27 p.

Foley, J.Y., Barker, J.C., and Brown, L.L., 1986, Chromite resources in Alaska, in Chromium/chromite: Assessment and research: U.S. Bureau of Mines Information Circular 9087, p. 23-29.

Folger, P.F., and Schmidt, J.M., 1986, Geology of the carbonate-hosted Omar copper prospect, Baird 
Mountains, Alaska: Economic Geology, v. 81, no. 7, p. 1690-1695.

Garner, G.W., and Reynolds, P.E., eds., 1983, 1982 update report, baseline study of the fish, wildlife, and their habitats; Section 1002(c) of the Alaska National Interest Lands Conservation Act: Anchorage, U.S. Fish and Wildlife Service, Region 7, $379 \mathrm{p}$.

-1984, 1983 update report, baseline study of the fish, wildlife, and their habitats; Section 1002(c) of the Alaska National Interest Lands Conservation Act: Anchorage, U.S. Fish and Wildlife Service, Region $7,614 \mathrm{p}$.

----1985, 1984 update report, baseline study of the fish, wildlife, and their habitats; Section 1002(c) of the Alaska National Interest Lands Conservation Act: Anchorage, U.S. Fish and Wildlife Service, Region $7,2 \mathrm{v}$.

--1986, Final report, baseline study of the fish, wildlife, and their habitats; Section 1002(c), Alaska National Interest Lands Conservation Act: Anchorage, U.S. Fish and Wildlife Service, Region 7,2 v.

Goldfarb, J.R., Leach, D.L., Miller, M.L., and Pickthorn, W.J., 1986, Geology, metamorphic setting, and genetic constraints of epigenetic lode-gold mineralization within the Cretaceous Valdez Group, south-central Alaska, in Keppie, J.D., Boyle, R.W., and Haynes, S.J., eds., Turbidite-hosted gold deposits: Geological Association of Canada Special Paper 32, p. 87-105.

Gryc, George, 1985, The National Petroleum Reserve in Alaska: Earth-science considerations: U.S. Geological Survey Professional Paper 1240-C, 94 p.

Hamilton, T.D., and Galloway, J.P., eds., 1987, The U.S. Geological Survey in Alaska--accomplishments during 1986: U.S. Geological Survey Circular 998, $205 \mathrm{p}$.

Hoekzema, R.B., and Fechner, S.A., 1986, Placer gold sampling in and near the Chugach National Forest, Alaska: U.S. Bureau of Mines Information Circular $9091,42 \mathrm{p}$.

Hoekzema, R.B., Fechner, S.A., and Bundtzen, T.K., 1986, Distribution, analysis, and recovery of placer gold from the Porcupine mining area, southeast Alaska: U.S. Bureau of Mines Open-File Report 86$86,49 \mathrm{p}$.

Hoekzema, R.B., Fechner, S.A., and Kurtak, J.M., 1987, Evaluation of selected lode gold deposits in the Chugach National Forest, Alaska: U.S. Bureau of Mines Information Circular 9112, 62 p.

Kurtak, J.M., 1986, Results of 1984 Bureau of Mines site specific field studies within the Willow Creek mining district, Alaska: U.S. Bureau of Mines Open-File Report 17-86, 17 p.

Leach, D.B., Goldfarb, R.J., and Light, T.D., 1986, Fluid inclusion constraints on the genesis of the AlaskaJuneau gold deposit [abs.]: Association of Exploration Geochemists Annual Meeting, Vancouver, British Columbia, Canada, 1986, Proceedings, p. 53-54.

Leonard, K.R., and Huber, D.F., 1987, Status of Alaska Mineral Resources Data System, in Hamilton, T.D., and Galloway, J.P., eds., The U.S. Geological Survey in Alaska--accomplishments during 1986: U.S. Geological Survey Circular 998, p. 15-18.

Maas, K.M., 1987, Maps summarizing land availability for mineral exploration and development in northern Alaska: U.S. Bureau of Mines Open-File Report 10-87, 33 quadrangle overlays, scale $1: 250,000$.
Magoon, L.B., ed., 1986, Geologic studies of the lower Cook Inlet COST No. I well, Alaska Outer Continental Shelf: U.S. Geological Survey Bulletin 1596, $99 \mathrm{p}$.

Magoon, L.B., 1987, Petroleum system--a classification scheme for research, resource assessment, and exploration [abs.]: American Association of Petroleum Geologists Bulletin, v. 71, no. 5, p. 587.

McNutt, S.R., and Jacob, K.H., 1986, Determination of large-scale velocity structure of the crust and upper mantle in the vicinity of Pavlof Volcano, Alaska: Journal of Geophysical Research, v. 91, no. B5, p. 5013-5022.

Meyer, M.P., 1986, Results of 1984 Bureau of Mines site specific mineral investigations in the Valdez Creek Mining District, Alaska: U.S. Bureau of Mines Open-File Report 50-86, 24 p.

Mining Engineering, 1986, Progress report on Cominco's Red Dog project in Alaska, second largest zinc deposit ever discovered: v.138, no. 12, p. 10971101 .

Mining Journal, 1986, Salt Chuck/Silver District review: v. 307, no. 7889, p. 322.

Molenaar, C.M., Bird, K.J., and Collett, T.S., 1986a, Regional correlation sections across the North Slope of Alaska: U.S. Geological Survey Miscellaneous Field Investigations Map MF-1907.

---1986b, Regional stratigraphic correlation sections across the North Slope of Alaska [abs.], in Carter, L.M.H., ed., USGS Research on Energy Resources--1986: Program and abstracts: U.S. Geological Survey Circular 974, p. 43.

Morgantown Energy Technology Center, 1986, Proceedings of the Gas Hydrates, Arctic/Offshore Research, and Deep Source Gas Contractors Review Meeting: reports DOE/METC-87/0247 and NTIS/DE87001028.

---1987a, Arctic and Offshore Research Technology Status Report: reports DOE/METC-87/0247 and NTIS/DE87001028, $32 \mathrm{p}$.

--1987b, Gas Hydrates Technology Status Report: reports DOE/METC-87/6046 and NTIS/DE87001027, $25 \mathrm{p}$.

----1987c, Deep Source Gas Technology Status Report: reports DOE/METC-87/0250 and NTIS/DE87001031, $18 \mathrm{p}$.

Motyka, R.J., Hawkins, D.B., Poreda, R.J., and Jeffries, W.A., 1986, Geochemistry, isotopic composition and the origin of fluids emanating from mud volcanoes in the Copper River Basin, Alaska: Alaska Division of Geological and Geophysical Surveys Public Data File 86-34, $87 \mathrm{p}$.

Nelson, S.W., Dumoulin, J.A., and Miller, M.L., 1986, Geologic map of the Chugach National Forest, Alaska: U.S. Geological Survey Miscellaneous Studies Map MF 1645-B, scale 1:250,000.

Nelson, S.W., and Koski, Randy, 1987, The Midas Mine-a stratiform $\mathrm{Fe}-\mathrm{Cu}-\mathrm{Zn}-\mathrm{Pb}$ sulfide deposit in Late Cretaceous turbidite near Valdez, Alaska [abs.]: Geological Society of America Abstracts with Programs, v. 19, no. 6, p. 436.

Nokleberg, W.J., Bundtzen, T.K., Berg, H.C., Brew, D.A., Grybeck, Donald, Smith, T.E., and Yeend, Warren, 1987, Significant metalliferous lode deposits and placer districts of Alaska: U.S. Geological Survey Bulletin 1786, 200 p.

Northern Miner, 1986, Queenstake gets interest in an Alaskan property: v. 72, no. 1, p. 12.

Oil and Gas Journal [published weekly by Pennwell Publishing Co., 1421 South Sheridan Road, Box 1260, Tulsa, OK 74101]. 
Pacific Oil World [published monthly by Petroleum Publishers, Inc., 222 South Brea Blvd., Brea, CA 92621].

Page, R.A., Plafker, George, Fuis, G.S., Nokleberg, W.J., Ambos, E.L., Mooney, W.D., and Campbell, D.L., 1986, Accretion and subduction tectonics in the Chugach Mountains and Copper River Basin, Alaska: Initial results of the Trans-Alaskan Crustal Transect: Geology, v. 14, p. 501-505.

Petroleum Information, Alaska Report [published weekly by Petroleum Information, a subsidiary of Dun and Bradstreet Corp., P.O. Box 102278, Anchorage, AK 99510].

Redman, E.C., 1986, History of the Juneau Gold Belt 1869-1965; development of the mines and prospects from Windham Bay to Berners Bay: U.S. Bureau of Mines Open-File Report 91-86, 78 p.

Redman, E.C., Roberts, W.S., Clough, A.H., and Kurtak, J.M., 1986, Preliminary mine, prospect, and sample location maps and descriptions, Juneau Gold Belt Area: U.S. Bureau of Mines Open-File Report 8586,68 p., 4 sheets, varying scales.

Retherford, R.M., Hinderman, T.K., and Hawley, C.C., 1986, Preliminary feasibility study of a coal mine at Chicago Creek, Alaska: Summary Report: Alaska Division of Geological and Geophysical Surveys Report of Investigations 86-13, 38 p.

Roberts, W.S., 1985, Maps showing availability of land for mineral exploration and development in southeastern Alaska, 1984: U.S. Bureau of Mines Special Report, 34 p., scale 1:500,000.

--1985, Maps summarizing land availability for mineral exploration and development in southeastern Alaska, 1984: U.S. Bureau of Mines Open-File Report 78-85, 15 quadrangle overlays, scale $1: 250,000$.

Schmidt, J.M., and Folger, P.F., 1986, Pb-Zn-Ag mineralization in Paleozoic dolostones, Powdermilk prospect, Baird Mountains B-4 quadrangle, in Bartsch-Winkler, Susan, and Reed, K.M., eds., Geologic studies in Alaska by the U.S. Geological Survey during 1985: U.S. Geological Survey Circular 978, p. 19-21.

Smith, R.L., and Shaw, H.R., 1975, Igneous-related geothermal systems, in White, D.E., and Williams, D.L., eds., Assessment of geothermal resources of the United States--1975: U.S. Geological Survey Circular 726, p. 58-83.

Southworth, D.D., and Foley, J.Y., 1986, Lode platinumgroup metals potential of the Goodnews Bay ultramafic complex, Alaska: U.S. Bureau of Mines Open-File Report 51-86, 82 p.

Stanley, R.G., 1987a, Effects of weathering on petroleum source evaluation of coals from the Suntrana Formation near Healy, Alaska, in Hamilton, T.D., and Galloway, J.P., eds., The U.S. Geological Survey in Alaska--accomplishments during 1986: U.S. Geological Survey Circular 998, p. 99-103.

---1987b, Thermal maturity and petroleum source potential of the Cantwell Formation, in Hamilton, T.D., and Galloway, J.P., eds., The U.S. Geological Survey in Alaska--accomplishments in Alaska during 1986: U.S. Geological Survey Circular 998, p. 104-107.

---1987c, Petroleum source potential and thermal maturity of Cantwell Formation (Paleocene), Central Alaska Range: a reconnaissance study [abs.]: American Association of Petroleum Geologists Bulletin, v. 71, no. 5, p. 617 .
Stricker, G.D., Affolter, R.H., and Brownfield, M.E., 1986, Geochemical characterization of selected coals from the Beluga energy resource area, southcentral Alaska: Site of a proposed coal mine [abs.], in Carter, L.M.H., ed., USGS research on energy resources--1986: Program and abstracts: U.S. Geological Survey Circular 974, p. 65-66.

Sutley, S.J., O'Leary, R.M., and Goldfarb, R.J., 1986, Analytical results and sample locality map of moraine-sediment, stream-sediment, and heavy mineral concentrate samples from the Cordova and Middleton Island $1^{\circ}$ by $3^{\circ}$ quadrangles, Alaska: U.S. Geological Survey Open-File Report 86-381, 117 p., scale $1: 250,000$.

Tailleur, I.L., and Weimer, Paul, eds., 1987, Alaskan North Slope Geology: Pacific Section, Society of Economic Paleontologists and Mineralogists and Alaska Geological Society, v. 50, 2 v., 800 p.

Till, A.B., Dumoulin, J.A., Gamble, B.M., and Kaufman, D.S., 1986, Preliminary geologic map and fossil data, Solomon, Bendeleben, and southern Kotzebue quadrangles, Seward Peninsula, Alaska: U.S. Geological Survey Open-File Report 86-276, 69 p., scale $1: 250,000,3$ sheets.

Tiratsoo, E.N., 1984, Oilfields of the world (3d ed.): Bucks, U.K., Scientific Press, 392 p.

Turner, D.L., and Wescott, E.M., eds., 1986, Geothermal energy resource investigations at Mt. Spurr, Alaska: Fairbanks, University of Alaska, Geophysical Institute Report UAG R-308, $111 \mathrm{p}$.

Updike, R.G., ed., 1986, Engineering geology technical feasibility study, Makushin geothermal power project, Unalaska, Alaska: Alaska Division of Geological and Geophysical Surveys Public Data File 86-60, 2 v.

U.S. Fish and Wildlife Service, 1986a, Kanuti National Wildlife Refuge, draft comprehensive conservation plan, wilderness review and environmental impact statement: Anchorage, Alaska, 219 p.

--1986b, Koyukuk and northern unit of Innoko National Wildlife Refuge, draft comprehensive conservation plan, environmental impact statement, and wilderness review: Anchorage, Alaska, 265 p.

---1986c, Nowitna National Wildlife Refuge, draft comprehensive conservation plan, wilderness review and environmental impact statement: Anchorage, Alaska, $287 \mathrm{p}$.

--1986d, Selawik National Wildlife Refuge, draft comprehensive conservation plan, wilderness review, wild river plan, and environmental impact statement: Anchorage, Alaska, $278 \mathrm{p}$.

-.--1986e, Togiak National Wildlife Refuge, final comprehensive conservation plan, wilderness review and environmental impact statement: U.S. Fish and Wildlife Service, Anchorage, Alaska, $514 \mathrm{p}$.

U.S. Fish and Wildlife Service, U.S. Geological Survey, and U.S. Bureau of Land Management, 1986, Arctic National Wildlife Refuge, Alaska, coastal plain resource assessment--draft report and recommendation to the Congress of the United States and legislative environmental impact statement: Washington, $186 \mathrm{p}$.

U.S. National Park Service, 1985, Guide to National Park Service regulations governing mining and mining claims: Denver, Colo., Energy, Mining and Minerals Division, $30 \mathrm{p}$.

Warner, J.D., Mardock, C.L., and Dahlin, D.C., 1986, A columbium-bearing regolith on Upper Idaho Gulch, near Tofty, Alaska: U.S. Bureau of Mines 
Information Circular 9105, $29 \mathrm{p}$.

Winkler, G.R., and Grybeck, D.J., 1986, The Alaska Mineral Resource Assessment Program in 1985, in Bartsch-Winkler, Susan, and Reed, K.M., eds., Geologic studies in Alaska by the U.S. Geological Survey during 1985: U.S. Geological Survey Circular 978, p. 3-5.

World Oil [published monthly by Gulf Publishing Co., 3301 Allen Parkway, Houston, TX 77019].

\section{APPENDIX 1.--ALASKA MINERAL REPORTS RELEASED DURING 1986 AND EARLY 1987}

The following selected references contain pertinent information about energy resources and other minerals in Alaska published during 1986 or early 1987. This is only a selection of germane reports from the publications of any agency. Reports by Federal or State agencies can generally be obtained from the agency of fices in Alaska, or they are available in the Alaska Resources Library, Federal Building, 701 C Street, Anchorage, AK 99513.

The USGS publishes a monthly listing of its own releases, "New Publications of the U.S. Geological Survey," available free from the U.S. Geological Survey, 582 National Center, Reston, VA 22092. The contents of these listings are compiled in an annual publication, "Publications of the U.S. Geological Survey, 198," also free. Information about the prices and sources of listed reports is given in these two publications and is available from the USGS Public Inquiries Of fices.

The USBM's central distribution office is the Branch of Production and Distribution, 4800 Forbes Ave., Pittsburgh, PA 15213. Many USBM reports are available from the U.S. Government Printing Office in Washington, D.C., or from the National Technical Information Service in Springfield, Va. USBM reports listed here are available from the USBM library in Juneau; for further information, contact the Chief, Alaska Field Operations Center, 201 East 9th Ave., Anchorage, AK 99501.

\section{DEPARTMENT OF THE INTERIOR}

\section{U.S. Geological Survey}

Publications with one or more USGS authors:

Affolter, R.H., and Stricker, G.D., 1986, Geochemistry of some Tertiary alluvial lowland coals from the Capps and Chuitna coal fields, Cook Inlet region, Alaska, in Garbini, Susan, and Schweinfurth, S.P., eds., Symposium proceedings: A national agenda for coal-quality research: U.S. Geological Survey Circular 979, p. 215.

Anders, D.E., and Magoon, L.B., 1986, Geochemical study of surface oil shows and potential source rocks in the Arctic National Wildlife Refuge (North Slope Alaska) [abs.], in Carter, L.M.H., ed., 1986, USGS research on energy resources--1986: Program and abstracts: U.S. Geological Survey Circular 974, p. $1-2$.

Angeloni, L.M., Wilson, F.H., and Sutley, Stephen, 1986, Map and tables showing preliminary rock geochemical data from Port Moller, Stepovak Bay, and Simeonof Island quadrangles, Alaska: U.S. Geological Survey Open-File Report 85-470, 180 p., scale $1: 250,000$.
Bader, J.W., and Bird, K.J., 1986, Geologic map of the Demarcation Point, Mt. Michelson quadrangles, northeastern Alaska: U.S. Geological Survey Miscellaneous Investigations Map I-1791, scale $1: 250,000$.

Barton, C.C., and Light, T.D., 1987, Structural fabric analysis of the Perseverance Slate and gold-bearing quartz veins in the south ore body of the AlaskaJuneau lode system, southeastern Alaska, in Hamilton, T.D., and Galloway, J.P., eds., The U.S. Geological Survey in Alaska--accomplishments during 1986: U.S. Geological Survey Circular 998, p. $110-112$.

Berg, H.C., 1986, Metallogenesis and mineral exploration in southeastern Alaska [abs.]: Geological Society of America Abstracts with Programs, v. 18 , no. 2, p. 84-85.

Bernstein, L.R., and Cox, D.P., 1986, Geology and sulfide mineralogy of the Number One ore body, Ruby Creek copper deposit, Alaska: Economic Geology, v. 81, no. 7, p. 1675-1689.

Bird, K.J., and Magoon, L.B., eds., 1987, Petroleum geology of the northern part of the Arctic National Wildlife Refuge, northeastern Alaska: U.S. Geological Survey Bulletin 1778, $711 \mathrm{p}$.

Bird, K.J., Magoon, L.B., and Molenaar, C.M., 1986, Advances in understanding North Slope oil and gas accumulations [abs.], in Carter, L.M.H., ed., USGS research on energy resources--1986: Program and abstracts: U.S. Geological Survey Circular 974, p. 6.

Bolm, J.G., and McCulloh, T.H., 1986, Sandstone diagenesis, in Magoon, L.B., ed., Geologic studies of the lower Cook Inlet COST No. I well, Alaska Outer Continental Shelf: U.S. Geological Survey Bulletin 1596, p. 51-53.

Bouma, A.H., and Hampton, M.A., 1986, Environmental geology, in Magoon, L.B., ed., Geologic studies of the lower Cook Inlet COST No. 1 well, Alaska Outer Continental Shelf: U.S. Geological Survey Bulletin 1596, p. 11-15.

Brew, D.A., Himmelberg, G.R., Ford, A.B., and Jachens, R.C., 1987, Ultramafic and mafic sills in the vicinity of the Treadwell gold deposits, Douglas Island, southeastern Alaska, in Hamilton, T.D., and Galloway, J.P., eds., The U.S. Geological Survey in Alaska--accomplishments during 1986: U.S. Geological Survey Circular 998, p. 119-123.

Bruns, T.R., von Huene, Roland, Culotta, R.D., Lewis, S.D., and Ladd, J.W., 1986, Geology and petroleum potential of Shumagin continental margin, western Gulf of Alaska [abs.]: American Association of Petroleum Geologists Bulletin, v. 70, no. 7, p. 915.

Carter, L.M.H., ed., 1986, USGS research on energy resources--1986: Program and abstracts: U.S. Geological Survey Circular 974, 84 p.

Church, S.E., Gray, J.E., and Delevaux, M.H., 1986, Use of $\mathrm{Pb}$-isotopic signatures for geochemical exploration in the Healy quadrangle, eastern Alaska Range, in Bartsch-Winkler, Susan, and Reed, K.M., eds., Geologic studies in Alaska by the U.S. Geological Survey during 1985: U.S. Geological Survey Circular 987, p. 38-41.

Claypool, G.E., 1986, Petroleum geochemistry, in Magoon, L.B., ed., Geologic studies of the lower Cook Inlet COST No. I well, Alaska Outer Continental Shelf: U.S. Geological Survey Bulletin 1596, p. 33-39.

Collett, T.S., Bird, K.J., Magoon, L.B., Kvenvolden, K.A., and Claypool, G.E., 1986, Gas hydrates, North 
Slope Alaska [abs.], in Carter, L.M.H., ed., USGS research on energy resources--1986: Program and abstracts: U.S. Geological Survey Circular 974, p. $11-12$.

Collett, T.S., Kvenvolden, K.A., Magoon, L.B., and Bird, K.J., 1987, Geochemical and geologic controls of the inferred occurrence of natural gas hydrate in the Kuparuk 2D-15 well, North Slope, Alaska, in Hamilton, T.D., and Galloway, J.P., eds., 1987, The U.S. Geological Survey in Alaska--accomplishments during 1986: U.S. Geological Survey Circular 998, p. 24-26.

Cooper, A.K., Marlow, M.S., and Scholl, D.W., 1986, Future hydrocarbon studies in the Bering Sea [abs.], in Carter, L.M.H., ed., USGS research on energy resources--1986: Program and abstracts: U.S. Geological Survey Circular 974, p. 12.

Cruz, E.L. and Cobb, E.H., compilers, 1986, Map showing occurrences of antimony minerals in Alaska: U.S. Geological Survey Mineral Investigations Resources Map MR-0093, 5 p., scale $1: 2,500,000$.

Csejtey, Bella, Jr., Mullen, M.W., Cox, D.P., Gilbert, W.G., Yeend, W.E., Smith T.E., Wahrhaftig, Clyde, Craddock, Campbell, Brewer, W.M., Sherwood, K.W., Hickman, R.G., Stricker, G.D., St. Aubin, D.R., and Goertz, D.J., III, 1986, Geology and geochronology of the Healy quadrangle, Alaska:U.S. Geological Survey Open-File Report 86-396, 96 p.

Dillon, J.T., Brosge, W.P., and Dutro, J.T., 1986, Generalized geologic map of the Wiseman quadrangle, Alaska: U.S. Geological Survey OpenFile Report 86-219, scale 1:250,000.

Duttweiler, K.A., 1986, Sulfide occurrences in the Itkillik River region, southeast Chandler Lake quadrangle, Brooks Range, in Bartsch-Winkler, Susan, and Reed, K.M., eds., Geologic studies in Alaska by the U.S. Geological Survey during 1985: U.S. Geological Survey Circular 978, p. 10-13.

-1987 , Use of factor analysis in locating base metal mineralization in the Killik River quadrangle, Alaska, in Hamilton, T.D., and Galloway, J.P., eds., The U.S. Geological Survey in Alaska-accomplishments during 1986: U.S. Geological Survey Circular 998, p. 27-30.

Egbert, R.M., 1986, Petrography, provenance, and tectonic significance of Middle and Upper Jurassic sandstone from Tuxedni Bay, in Magoon, L.B., ed., Geologic studies of the lower Cook Inlet COST No. 1 well, Alaska Outer Continental Shelf: U.S. Geological Survey Bulletin 1596, p. 61-63.

Ellersieck, Inyo, and Tailleur, I.L., 1986, The strategic and critical mineral resources of the southern part of the National Petroleum Reserve in Alaska: U.S. Geological Survey Open-File Report 86-0158, 12 p.

Fisher, M.A., von Huene, Roland, and Hampton, M.A., 1986, Summary geologic report for petroleum lease sale 非100, Kodiak shelf, Alaska: U.S. Geological Survey Open-File Report 84-24, 51 p.

Folger, P.F., Goldfarb, R.J., and Schmidt, J.M., 1987, Geochemical evaluation of the Baird Mountains quadrangle, Alaska, in Hamilton, J.D., and Galloway, J.P., eds., The U.S. Geological Survey in Alaska--accomplishments during 1986: U.S. Geological Survey Circular 998, p. 31-34.

Folger, P.F., and Schmidt, J.M., 1986, Geology of the carbonate-hosted Omar copper prospect, Baird Mountains, Alaska: Economic Geology, v. 81, no. 7, p. 1690-1695.
Goldfarb, R.J., Leach, D.L., Miller, M.L., and Pickthorn, W.J., 1986, Geology, metamorphic setting, and genetic constraints of epigenetic lode-gold mineralization within the Cretaceous Valdez Group, south-central Alaska, in Keppie, J.D., Boyle, R.W., and Haynes, S.J. eds., Turbidite-hosted gold deposits: Geological Association of Canada Special Paper 32, p. 87-105.

Goldfarb, R.J., Light, T.D., and Leach, D.L., 1986, Nature of the ore fluids at the Alaska-Juneau gold deposit, in Bartsch-Winkler, Susan, and Reed, K.M., eds., Geologic studies in Alaska by the U.S. Geological Survey during 1985: U.S. Geological Survey Circular 978, p. 92-95.

Gray, J.E., Church, S.E., and Delevaux, M.H., 1986, Lead-isotope results from gold-bearing quartz veins from the Valdez and Orca Groups, Chugach National Forest, in Bartsch-Winkler, Susan, and Reed, K.M., eds., Geologic studies in Alaska by the U.S. Geological Survey during 1985: U.S. Geological Survey Circular 978, p. 45-50.

Gryc, George, ed., 1987, National Petroleum Reserve in Alaska: U.S. Geological Survey Professional Paper 1399,38 p. (in press).

Hamilton, T.D., and Galloway, J.P., eds., 1987, The U.S. Geological Survey in Alaska--accomplishments during 1986: U.S. Geological Survey Circular 998, $199 \mathrm{p}$.

Harris, A.G., Tailleur, I.L., and Lane, H.R., 1986, Conodont thermal maturation patterns in Paleozoic and Triassic rocks, northern Alaska - geologic and exploration implications [abs.], in Carter, L.M.H., ed., 1986, USGS research on energy resources-1986: Program and abstracts: U.S. Geological Survey Circular 974, p. 21.

Hitzman, M.W., Proffett, J.M., Jr., Schmidt, J.M., and Smith, T.E., 1986, Geology and mineralization of the Ambler district, northwestern Alaska: Economic Geology, v. 81, no. 7, p. 1592-1618.

Jenson, S.K. and Trautwein, C.M., 1986, Definition of multivariate geochemical associations with polymetallic mineral occurrences using a spatially dependent clustering technique and rasterized stream sediment data; an Alaskan example [abs.]: Journal of Geochemical Exploration, in Nichols, C.E., ed., Exploration for ore deposits of the North American Cordillera, v. 25, no. 1-2, p. 242.

Keith, T.E.C., Page, N.J., Oscarson, R.L., and Foster, H.L, 1987, Platinum-group element concentrations in a biotite-rich clinopyroxenite suite, Eagle C-3 quadrangle, Alaska, in Hamilton, T.D., and Galloway, J.P., eds., The U.S. Geological Survey in Alaska--accomplishments during 1986: U.S. Geological Survey Circular 998, p. 62-66.

Koch, R.D., Brew, D.A., and Ford, A.B., 1987, Newly discovered molybdenite occurrence near Boundary Creek, Coast Mountain, southeastern Alaska, in Hamilton, T.D., and Galloway, J.P., eds., 1987, The U.S. Geological Survey in Alaska--accomplishments during 1986: U.S. Geological Survey Circular 998, p. 124-125.

Leach, D.B., Goldfarb, R.J., and Light, T.D., 1986, Fluid inclusion constraints on the genesis of the AlaskaJuneau gold deposit [abs.]: Association of Exploration Geochemists Annual Meeting, Vancouver, British Columbia, Canada, 1986, Proceedings, p. 53-54.

Leonard, K.R., and Huber, D.F., 1987, Status of Alaska Mineral Resources Data System, in Hamilton, T.D., and Galloway, J.P., eds., The U.S. Geological 
Survey in Alaska--accomplishments during 1986: U.S. Geological Survey Circular 998, p. 15-18.

Light, T.D., Cady, J.W., Weber, F.R., McCammon, R.B., and Rinehart, C.D., 1987, Sources of placer gold in the southern part of the White Mountains National Recreation Area, east-central Alaska, in Hamilton, T.D., and Galloway, J.P., eds., The U.S. Geological Survey in Alaska--accomplishments during 1986: U.S. Geological Survey Circular 998, p. 67-69.

Loney, R.A., Himmelberg, G.R., and Shew, Nora, 1987, Salt Chuck palladium-bearing ultramafic body, in Hamilton, T.D., and Galloway, J.P., eds., The U.S. Geological Survey in Alaska--accomplishments during 1986: U.S. Geological Survey Circular 998, p. 126-127.

Magoon, L.B., ed., 1986, Geologic studies of the lower Cook Inlet COST No. I well, Alaska Outer Continental Shelf: U.S. Geological Survey Bulletin 1596, 99 p.

Menzie, W.D., Reed, B.L., and Keith, T.E.C., 1986, Lime Peak--an evolved granite with tin-enriched alteration, in Bartsch-Winkler, Susan, and Reed, K.M., eds., Geologic studies in Alaska by the United States Geological Survey during 1985: U.S. Geological Survey Circular 978, p. 25-27.

Molenaar, C.M., Bird, K.J., and Collett, T.S., 1986, Regional correlation sections across the North Slope of Alaska [abs.], in Carter, L.M.H., ed., USGS research on energy resources--1986: Program and abstracts: U.S. Geological Survey Circular 974, p. 43.

---1986, Regional correlation sections across the North Slope of Alaska: U.S. Geological Survey Miscellaneous Field Investigations Map MF-1907.

Mosier, E.L., and Lewis, J.S., 1986, Analytical results, geochemical signatures, and sample locality map of lode gold, placer gold, and heavy-mineral concentrates from the Koyukuk-Chandalar mining district, Alaska: U.S. Geological Survey Open-File Report 86-345, $174 \mathrm{p}$.

Nelson, S.W., Dumoulin, J.A., and Miller, M.L., 1986, Geologic map of the Chugach National Forest, Alaska: U.S. Geological Survey Miscellaneous Studies Map MF-1645-B, scale 1:250,000.

Nelson, S.W., and Koski, Randy, 1986, The Midas Mine-a stratiform $\mathrm{Fe}-\mathrm{Cu}-\mathrm{Zn}-\mathrm{Pb}$ sulfide deposit in Late Cretaceous turbidite near Valdez, Alaska [abs.]: Geological Society of America Abstracts with Programs, v. 19, no. 6, p. 436.

Newberry, R.J., and Brew, D.A., 1987, The AlaskaJuneau gold deposit; remobilized syngenetic versus exotic epigenetic origin, in Hamilton, T.D., and Galloway, J.P., eds., The U.S. Geological Survey in Alaska--accomplishments during 1986: U.S. Geological Survey Circular 998, p. 128-131.

Nokleberg, W.J., Bundtzen, T.K., Berg, H.C., Brew, D.A., Grybeck, Donald, Smith, T.E., and Yeend, Warren (plus 55 contributors), 1987, Significant metalliferous lode deposits and placer districts of Alaska: U.S. Geological Survey Bulletin 1786, 200 p., scale $1: 5,000,000,2$ sheets.

Nokleberg, W.J., Bundtzen, T.K., Berg, H.C., Brew, D.A., Grybeck, Donald, and Yeend, W.E., 1987, Metallogeny and major mineral deposits of Alaska: Alaskan Decade of North American Geology, Geological Society of America, $154 \mathrm{p}$.

Odum, J.K., Gardner, C.A., Schmoll, H.R., Yehle, L.A., and Dearborn, L.L., 1986, Lithologic, geotechnical, and geophysical data for drill hole CE-82-1, Chuitna East coal field, Cook Inlet region, Alaska:
U.S. Geological Survey Bulletin 1637, 9 p.

O'Leary, R.M., Hoffman, J.D., Risoli, D.A., and Tripp, R.B., 1986, Analytical results and sample locality map of stream-sediment and heavy-mineral concentrate samples from the Circle quadrangle, Alaska: U.S. Geological Survey Open-File Report 86-204, 126 p.

Page, R.A., Plafker, George, Fuis, G.S., Nokleberg, W.J., Ambos, E.L., Mooney, W.D., and Campbell, D.L., 1986, Accretion and subduction tectonics in the Chugach Mountains and Copper River Basin, Alaska: Initial results of the Trans-Alaskan Crustal Transect: Geology, v. 14, p. 501-505.

Parrish, J.T., 1986, The Shublik Formation--a model for deposition in an ancient marine upwelling zone [abs.], in Carter, L.M.H., ed., USGS research on energy resources--1986: Program and abstracts: U.S. Geological Survey Circular 974, p. 54.

Prensky, S.E., 1986, List of released wells and availability of digital well-log data for Atlantic, Pacific and Alaskan OCS regions through December 31, 1985: U.S. Geological Survey Open-File Report 86-48, 40 p.

Rosenblum, Sam, Carlson, R.R., Nishi, J.M., and Overstreet, W.C., 1986, Platinum-group elements in magnetic concentrate from the Goodnews Bay district, Alaska: U.S. Geological Survey Bulletin $1660,38 \mathrm{p}$.

Sable, E.G., Stricker, G.D., and Affolter, R.H., 1986, Nanushuk Group coal investigations--Nor th Slope of Alaska [abs.], in Carter, L.M.H., ed., USGS research on energy resources--1986: Program and abstracts: U.S. Geological Survey Circular 974, p. 59-60.

Schmidt, J.M., 1986, Stratigraphic setting and mineralogy of the Arctic volcanogenic massive sulfide prospect, Ambler district, Alaska: Economic Geology, v. 81, no. 7, p. 1619-1643.

Schmidt, J.M., and Folger, P.F., 1986, Pb-Zn-Ag mineralization in Paleozoic dolostones, Powdermilk prospect, Baird Mountains B-4 quadrangle, in Bartsch-Winkler, Susan, and Reed, K.M., eds., Geologic studies in Alaska by the U.S. Geological Survey during 1985: U.S. Geological Survey Circular 978, p. 19-21.

----1987, Organic content and rockeval pyrolysis of carbonate rocks from the Omar copper project, Baird Mountains, Alaska, in Hamilton, T.D., and Galloway, J.P., eds., The U.S. Geological Survey in Alaska--accomplishments during 1986: U.S. Geological Survey Circular 998, p. 43-46.

Stanley, R.G., 1987, Effects of weathering on petroleum-source evaluation of coals from the Suntrana Formation near Healy, Alaska, in Hamilton, T.D., and Galloway, J.P., eds., The U. $\bar{S}$. Geological Survey in Alaska--accomplishments during 1986: U.S. Geological Survey Circular 998, p. 99-103.

-.-1987, Thermal maturity and petroleum source potential of the Cantwell Formation, in Hamilton, T.D., and Galloway, J.P., eds., The U.S. Geological Survey in Alaska--accomplishments in Alaska during 1986: U.S. Geological Survey Circular 998, p. $104-107$.

Stevenson, A.J., and Vallier, T.L., 1986, Evolution, structure, and petroleum potential of Aleutian subduction complex [abs.]: American Association of Petroleum Geologists Bulletin, v. 70, no. 7, p. 935.

Stricker, G.D., Affolter, R.H., and Brownfield, M.E., 
1986, Geochemical characterization of selected coals from the Beluga energy resource area, southcentral Alaska: site of a proposed coal mine [abs.], in Carter, L.M.H., ed., 1986, USGS research on energy resources--1986: Program and abstracts: U.S. Geological Survey Circular 974, p. 65-66.

Sutley, S.J., O'Leary, R.M., and Goldfarb, R.J., 1986, Analytical results and sample locality map of moraine-sediment, stream-sediment, and heavy mineral concentrate samples from the Cordova and Middleton Island $1^{\circ}$ by $3^{\circ}$ quadrangles, Alaska: U.S. Geological Survey Open-File Report 86-381, 117 p., scale $1: 250,000$.

Tailleur, I.L., and Weimer, Paul, eds., 1987, Alaskan North Slope geology: Pacific Section, Society of Economic Paleontologists and Mineralogists, v. 50, 2 v., 800 p.

Till, A.B., Dumoulin, J.A., Gamble, B.M., and Kaufman, D.S., 1986, Preliminary geologic map and fossil data, Solomon, Bendeleben, and southern Kotzebue quadrangles, Seward Peninsula, Alaska: U.S. Geological Survey Open-File Report 86-276, 69 p., scale $1: 250,000,3$ sheets.

Updike, R.G., and Carpenter, B.A., 1986, Engineering geology of the Government Hill area, Anchorage, Alaska: U.S. Geological Survey Bulletin 1588, 32 p.

von Huene, Roland, 1986, Potential gas generation in subducted sediments of the eastern Aleutian Trench area [abs.], in Carter, L.M.H., ed., 1986, USGS research on energy resources--1986: Program and abstracts: U.S. Geologica! Survey Circular 974, p. 69.

White, E.R., Galloway, J.P., and Booth, S.E., compilers, 1986, Reports about Alaska in USGS publications released in 1985, in Bartsch-Winkler, Susan, and Reed, K.M., eds., Geologic studies in Alaska by the U.S. Geological Survey during 1985: U.S. Geological Survey Circular 978, p. 146-159.

----1986, Reports about Alaska in non-USGS publications in 1985 that include USGS authors, in Bartsch-Winkler, Susan, and Reed, K.M., eds., Geologic studies in Alaska by the U.S. Geological Survey during 1985: U.S. Geological Circular 978, p. $160-168$.

Wiley, T.J., 1986, Tectonics--first order control of sediment distribution and hydrocarbon potential: examples from the western margin of North America [abs.], in Carter, L.M.H., ed., USGS research on energy resources--1986: Program and abstracts: U.S. Geological Survey Circular 974, p. 74-75.

Winkler, G.R., 1986, Data releases and folio reports prepared for the Alaska Mineral Resource Assessment Program and the Regional Alaska Mineral Resource Assessment Program listed alphabetically by quadrangle, in Bartsch-Winkler, Susan, and Reed, K.M., eds., Geologic studies in Alaska by the U.S. Geological Survey during 1985: U.S. Geological Survey Circular 978, p. 110-145.

Winkler, G.R. and Grybeck, D.J., 1986, The Alaska Mineral Resource Assessment Program in 1985, in Bartsch-Winkler, Susan and Reed, K.M., eds., Geologic studies in Alaska by the U.S. Geological Survey during 1985: U.S. Geological Survey Circular 978, p. 3-5.

Yeend, Warren, 1987, Placer gold related to mafic schist? Circle District, in Hamilton, T.D., and Galloway, J.P., eds., The U.S. Geological Survey in Alaska--accomplishments during 1986: U.S. Geological Survey Circular 998, p. 74-76.

\section{U.S. Bureau of Mines}

Barker, J.C., 1986, Platinum-group metals, gold and chromiun resource potential offshore of Platinum, Alaska [abs.]: presented at 16th Annual Underwater Mining Conference, November 1986, Biloxi, Miss. [Available at U.S. Bureau of Mines Library, Juneau, Alaska].

Barker, J.C., and Foley, J.Y., 1986, Tin reconnaissance of the Kanuti and Hodzana rivers uplands, central Alaska: U.S. Bureau of Mines Information Circular $9104,27 \mathrm{p}$.

Barker, J.C. and Swainbank, R.C., 1986, A tungsten-rich porphyry molybdenum occurrence at Bear Mountain, northeast Alaska: Economic Geology, v. 81 , no. 7, p. 171-177.

Bottge, R.G., 1986, Company towns versus company camps in developing Alaska's mineral resources: U.S. Bureau of Mines Information Circular 9107, 19 p.

---1986, Availability of land for mineral exploration and development in Alaska: presented at Alaska Miners Association Convention, October 1986, Anchorage, Alaska, 7 p. [Available at U.S. Bureau of Mines Library, Juneau, Alaska].

---1986, Maps summarizing land availability for mineral exploration and development in northcentral Alaska: U.S. Bureau of Mines OpenFile Report 70-86, 14 quadrangle overlays, scale 1:250,000, and U.S. Bureau of Mines Special Report, scale $1: 500,000$.

---1986, Maps summarizing land availability for mineral exploration and development in southcentral Alaska: U.S. Bureau of Mines OpenFile Report 71-86, 21 quadrangle overlays, scale $1: 250,000$, and U.S. Bureau of Mines Special Report, scale $1: 500,000$.

Daellenbach, C.B., compiler, 1986, Chromiumchromite: Bureau of Mines assessment and research; proceedings of Bureau of Mines briefing held at Oregon State University, Corvallis, Oregon, June 4-5, 1985: U.S. Bureau of Mines Information Circular 9087,141 p.

Fechner, S.A., 1986, 1984 sample results for Bureau of Mines site specific mineral investigations within the Yentna mining district, Alaska: U.S. Bureau of Mines Open-File Report 28-86, 53 p.

Fechner, S.A. and Hoekzema, R.B., 1986, Distribution, analysis, and recovery of gold from Kantishna placers, Alaska: U.S. Bureau of Mines Open-File Report $1-86,54 \mathrm{p}$.

Foley, J.Y. and Barker, J.C., 1986, Uranium occurrences on the northern Darby Mountains, Seward Peninsula, Alaska: U.S. Bureau of Mines Information Circular 9103, $27 \mathrm{p}$.

Foley, J.Y., Barker, J.C., and Brown, L.L., 1986, Chromite resources in Alaska, in Chromium/chromite: Assessment and research: U.S. Bureau of Mines Information Circular 9087, p. 23-29.

Hoekzema, R.B. and Fechner, S.A., 1986, Placer gold sampling in and near the Chugach National Forest, Alaska: U.S. Bureau of Mines Information Circular 9091,42 p.

Hoekzema, R.B., Fechner, S.A., and Bundtzen, T.K., 1986, Distribution, analysis, and recovery of placer gold from the Porcupine mining area, southeast Alaska: U.S. Bureau of Mines Open-File Report 86$86,49 \mathrm{p}$.

Hoekzema, R.B., Fechner, S.A., and Kurtak, J.M., 1987, 
Evaluation of selected lode gold deposits in the Chugach National Forest, Alaska: U.S. Bureau of Mines Information Circular 9113, $62 \mathrm{p}$.

Kurtak, J.M., 1986, Results of 1984 Bureau of Mines site specific field studies within the Willow Creek mining district, Alaska: U.S. Bureau of Mines Open-File Report 17-86, 17 p.

Kurtak, J.M. and Jeske, R.E., 1986, Mineral investigations in the Chugach National Forest, Alaska (islands area): U.S. Bureau of Mines OpenFile Report 54-86, 302 p.

Maas, K.M., 1987, Maps summarizing land availability for mineral exploration and development in northern Alaska: U.S. Bureau of Mines Open-File Report 10-87, 33 quadrangle overlays, scale $1: 250,000$.

Meyer, M.P., 1986, Results of 1984 Bureau of Mines site specific mineral investigations in the Valdez Creek Mining District, Alaska: U.S. Bureau of Mines Open-File Report 50-86, 24 p.

Pittman, T.L., 1986, The mineral industry of Alaska, in U.S. Bureau of Mines Minerals Yearbook, 1985, $\bar{v}$. II, Area Reports, Domestic: U.S. Bureau of Mines, (in press).

-..-1986, The mineral industry of Alaska in 1986: U.S. Bureau of Mines Mineral Industry Surveys, 2 p.

Redman, E.C., 1986, History of the Juneau Gold Belt 1869-1965: Development of the mines and prospects from Windham Bay to Berners Bay: U.S. Bureau of Mines Open-File Report 91-86, 78 p.

Redman, E.C., Roberts, W.S., Clough, A.H., and Kurtak, J.M., 1986, Preliminary mine, prospect, and sample location maps and descriptions, Juneau Gold Belt Area: U.S. Bureau of Mines Open-File Report 8586,68 p., 4 sheets, varying scales.

Southworth, D.D. and Foley, J.Y., 1986, Lode platinumgroup metals potential of the Goodnews Bay ultramafic complex, Alaska: U.S. Bureau of Mines Open-File Report 51-86, 82 p.

Warner, J.D., Mardock, C.L., and Dahlin, D.C., 1986, A columbium-bearing regolith on Upper Idaho Gulch, near Tofty, Alaska: U.S. Bureau of Mines Information Circular 9105, 29 p.

\section{Fish and Wildlife Service}

Clough, N.K., Patton, P.C., and Christiansen, A.C., eds., 1987, Arctic National Wildlife Refuge, Alaska, coastal plain resource assessment--report and recommendation to the Congress of the United States and final legislative environment impact statement: Washington, U.S. Fish and Wildlife Service, U.S. Geological Survey, and U.S. Bureau of Land Management, $2 \mathrm{v}$.

Elison, G.W., Rappoport, A.G., and Reid, G.M., 1986, Report of the caribou impact analysis workshop, Arctic National Wildlife Refuge, November 19-20, 1985: Fairbanks, Alaska, U.S. Fish and Wildlife Service, 39 p.

Garner, G.W., and Reynolds, P.E., eds., 1986, Final report, baseline study of the fish, wildlife, and their habitats, Section 1002(c) of the Alaska National Interest Lands Conservation Act: Anchorage, Alaska, U.S. Fish and Wildlife Service, Region 7, 2 v.

U.S. Fish and Wildlife Service, 1986, Kanuti National Wildlife Refuge, draft comprehensive conservation plan, wilderness review and environmental impact statement: Anchorage, Alaska, 219 p.

---1986, Koyukuk and northern unit of Innoko National
Wildlife Refuge, draft comprehensive conservation plan, environmental impact statement: Anchorage, Alaska, $265 \mathrm{p}$.

--.-1986, Nowitna National Wildlife Refuge, draft comprehensive conservation plan, wilderness review and environmental impact statement: Anchorage, Alaska, 287 p.

----1986, Selawik National Wildlife Refuge, draft comprehensive conservation plan, wilderness review, wild river plan, and environmental impact statement: Anchorage, Alaska, 278 p.

----1986, Togiak National Wildlife Refuge, final comprehensive conservation plan, wilderness review and environmental impact statement: Anchorage, Alaska, 514 p.

U.S. Fish and Wildlife Service, U.S. Geological Survey, and U.S. Bureau of Land Management, 1986, Arctic National Wildlife Refuge, Alaska, coastal plain resource assessment--draft report and recommendation to the Congress of the United States and legislative environmental impact statement: Washington, $172 \mathrm{p}$.

West, R.L., 1986, Baseline histopathological and contaminant studies of four arctic fish species in Beaufort Lagoon, Arctic National Wildlife Refuge, Alaska: Fairbanks, Alaska, U.S. Fish and Wildlife Service, Fishery Resources Progress Report No. FY 86-4.

\section{National Park Service}

Deschu, Nancy, 1986, Turbidity and settleable solids in mined and unmined streams in the Kantishna Hills, Denali National Park and Preserve: U.S. National Park Service, Alaska Regional Office, Research/Resources Management Report AR-7.

U.S. National Park Service, 1986, Environmental assessment and analysis, proposed plan of operations, Trinity Mining, Humbolt Creek, Bering Land Bridge National Preserve: Alaska Regional Office, 49 p.

----1986, Environmental assessment and Regional Director's analysis, 1986 Plan of Operations for Edison Association placer claim, Wrangell-St. Elias National Park and Preserve, Alaska: Alaska Regional Office, $54 \mathrm{p}$.

--1986, Environmental assessment and Regional Director's analysis, 1986 Plan of Operations for Sunshine Lode patented claim (Nabesna Mine), Wrangell-St. Elias National Park and Preserve, Alaska: Alaska Regional Office, 51 p.

---1986, Environmental handbook for cyanide leaching projects: Intermountain Soils, Inc., Denver, Colo., $57 \mathrm{p}$.

---1986, Reclamation research plans for Alaska National Park System units: Environmental Science and Engineering, Inc., and Beck Consultants, Inc., $104 \mathrm{p}$.

\section{Department of Energy}

List includes publications resulting from DOE-sponsored research:

Feyk, C., and Sackinger, W.M., 1986, Formation of surface films at a sea ice/steel interface under impressed current conditions: International Symposium on Arctic Corrosion, Ist, Corrosion/86, National Association of Corrosion Engineers Conference, Houston, Tex., 1986, Proceedings. 
Kovacs, Austin, Morey, R.M., Cox, G.F.N., and Valleau, N.C., 1987, Electromagnetic property trends in sea ice: U.S. Army Corps of Engineers, Cold Regions Research and Engineering Laboratory, CRREL Report 87-6, 45 p.

Morgantown Energy Technology Center, 1986, Proceedings of the Gas Hydrates, Arctic/Offshore Research, and Deep Source Gas Contractors Review Meeting: reports DOE/METC-86/6037 and NTIS/DE86006404.

---1987, Arctic and Offshore Research Technology Status Report: reports DOE/METC-87/0247 and NTIS/DE87001028, 32 p.

----1987, Gas Hydrates Technology Status Report: reports DOE/METC-87/6046 and NTIS/DE86001027, $25 \mathrm{p}$.

-1987, Deep Source Gas Technology Status Report: reports DOE/METC-867/0250 and NTIS/DE87001031, $18 \mathrm{p}$.

Sackinger, W.M., Feyk, C., and Shoemaker, H.D., 1986, Spray ice formation characteristics, and adhesion to ship and structure coatings: Annual Arctic Offshore Technology Conference and Exhibition, 3d, Calgary, Alberta, Canada, 1986.

Sackinger, W.M., Norlund, O.P., and Shoemaker, H.D., 1986, Low adhesion coatings for sea spray ice on offshore drilling units in northern waters: International Offshore and Navigation Conference and Exhibition, Helsinki, Finland, 1986, Proceedings, p. 512-527.

Scott, J.H., Petersen, J.K., Osterkamp, T.E., and Kawasaki, K., 1986, Interpretation of geophysical well logs in permafrost: $\mathrm{DOE} / \mathrm{BC} / 10810-1938$ and NTIS/DE86001052, 124 p.

Shoemaker, H.D., 1986, Arctic and Offshore Research Information System (AORIS): Annual Arctic Offshore Technology Conference Exhibition, 3d, Calgary, Alberta, Canada, 1986.

Theuveny, B., and Sackinger, W.M., 1986, Method of calculation of cathodic protection for current distribution for steel of fshore structures in the Arctic: International Symposium on Arctic Corrosion, 1st. Corrosion/86, National Association of Corrosion Engineers Conference, Houston, Tex., 1986.

Turner, D.L., and Wescott, E.M., eds., 1986, Geothermal energy resource investigations at Mt. Spurr, Alaska: Fairbanks, University of Alaska, Geophysical Institute Report UFAG R-308, 111 p.

\section{OTHER FEDERAL AGENCIES}

Godfrey, R.N., and Eaton, R.A., 1986, Engineering surveys along the Trans-Alaska Pipeline: U.S. Army, Cold Regions Research and Engineering Laboratory Special Report 86-28, 85 p. [Available from CRREL, 72 Lyme Road, Hanover, NH, 03755].

\section{NON-FEDERAL REPORTS}

\section{Alaska Division of Geological and Geophysical Surveys}

List includes publications by the ADGGS and outside publications with ADGGS authors:

Alaska Division of Geological and Geophysical Surveys, 1986, Arctic National Wildlife Refuge: Public Data File 86-86.

-1986, Geological and mining consultants available for work in Alaska, revised July, 1986: Information
Circular 8, 32 p.

1986, Oil-and-gas resources of Alaska: Information

Circular 31, 9 p.

---1986, Resource information--Upper Kuskokwim River Basin Land-Use Plan: Public Data File 86-53.

1986, Summary of existing data and potential for commercial hydrocarbon accumulations, Bristol Bay, Alaska: Public Data File 86-13, 20 p.

-1987, Map of Division of Geological and Geophysical Surveys publications with author and quadrangle indexes, revised January 15, 1987: Information Circular 23, 5 p., scale 1:3,265,000.

Bundtzen, T.K., 1986, Placer geology of the Porcupine Mining District, Skagway B-4 quadrangle, Alaska: Alaska Division of Geological and Geophysical Surveys Public Data File 86-27, 26 p.

-.-1986, Prospect examination of a gold-tungsten placer deposit at Alder Creek, Vinasale Mountain area, western Alaska, Alaska Division of Geological and Geophysical Surveys Public Data File 86-15, 10 p.

Bundtzen, T.K., and Clautice, K.H., 1986, Prospect examination of the Golden Eagle lode-gold prospect near Porcupine, Skagway B-4 quadrangle, Alaska: Alaska Division of Geological and Geophysical Surveys Public Data File 86-18, 7 p.

Bundtzen, T.K. and Eakins, G.R., Green, C.B., and Lueck, L.L., 1986, Alaska's Mineral Industry-1985: Alaska Division of Geological and Geophysical Surveys Special Report 39, 68 p.

Bundtzen, T.K., and Kline, J.T., 1986, Coal, peat, and geothermal potential of Kuskokwim Area Plan: Alaska Division of Geological and Geophysical Surveys Public Data File 86-88, 13 p.

Bundtzen, T.K., Miller, M.L., and Laird, G.M., 1986, Prospect examination of the Wyrick placer/lode system, Granite Creek, Iditarod-George mining district, Iditarod B-2 quadrangle, Alaska: Alaska Division of Geological and Geophysical Surveys Public Data File 86-29, 10 p.

Eakins, G.R., and Kline, J.T., 1986, Chicago Creek coal investigation: summary of field trip, September 813, 1980: Alaska Division of Geological and Geophysical Surveys Public Data File 86-30, 7 p.

Forbes, R.B., Kline, J.T., Clough, A.H., 1987, A preliminary investigation of alluvial diamond discoveries in placer gravels of Crooked Creek, Circle District, Alaska: Alaska Division of Geological and Geophysical Surveys Report of Investigations 87-2, scale $1: 63,360$.

Goff, K.M., 1986, Slide presentation on Alaska coal: Alaska Division of Geological and Geophysical Surveys Public Data File 86-31, 49 p.

Hansen, J.J., and Kornbrath, R.W., compilers, 1986, Resource appraisal simulation for petroleum in the Arctic National Wildlife Refuge, Alaska: Alaska Division of Geological and Geophysical Surveys Professional Report 90, 13 p.

Hitzman, M.W., 1986, Geology of the Ruby Creek copper deposit, southwestern Brooks Range, Alaska: Economic Geology, v. 81, no. 7, p. 16441674.

Johnson, Kurt, 1986, DGGS Alaská coal regions data base: Alaska Division of Geological and Geophysical Surveys Public Data File 86-87, 64 p.

Mack, S.F., 1986, Using turbidity to predict total suspended solids in mined streams in interior Alaska: Alaska Division of Geological and Geophysical Surveys Public Data File 86-84, 108 p.

Mack, S.F., and Moorman, M.A., 1986 Hydrologic and 
water-quality investigations related to the occurrence of placer mining in interior Alaska, summers 1984-1985: Alaska Division of Geological and Geophysical Surveys Public Data File 86-16, $138 \mathrm{p}$.

Manning, K.H., and Stevens, D.L., 1986, The Chicago Creek and Norton Sound area, coal exploration programs, 1982: Alaska Division of Geological and Geophysical Surveys Public Data File 86-58, 103 p.

Maurer, M.A., 1986, Chemical and biological water quality of selected streams in the Beluga coal area, Alaska: Alaska Division of Geological and Geophysical Surveys Public Data File 86-51, 59 p.

Merritt, R.D., 1986, Alaska coal fields and seams: Alaska Division of Geological and Geophysical Surveys Public Data File 86-67, 41 p.

---1986, Alaska: Coal fields and seams: Alaska Division of Geological and Geophysical Surveys Public Data File 86-90, 55 p.

----1986, Analysis of Beluga lease sale and coal exports (1982): Alaska Division of Geological and Geophysical Surveys Public Data File 86-93, 15 p.

----1986, Characterization of Alaska coal overburden: Alaska Division of Geological and Geophysical Surveys Public Data File 86-64, 42 p.

-.-1986, Chronicle of Alaska coal-mining history: Alaska Division of Geological and Geophysical Surveys Public Data File 86-66, 25 p.

----1986, Coal geology and resources of the Matanuska Valley, Alaska: Alaska Division of Geological and Geophysical Surveys Public Data File 86-76, 93 p.

----1986, Coal geology and resources of the Nenana Basin, Alaska: Alaska Division of Geological and Geophysical Surveys Public Data File 86-74, 70 p.

----1986, Coal geology and resources of the Susitna lowland, Alaska: Alaska Division of Geological and Geophysical Surveys Public Data File 86-75, 98 p.

--1986, Coal reports of the Alaska Division of Geological and Geophysical Surveys (1984): Alaska Division of Geological and Geophysical Surveys Public Data File 86-94, 5 p.

---1986, Coal reports of the State of Alaska Department of Natural Resources Division of Geological and Geophysical Surveys: Alaska Division of Geological and Geophysical Surveys Public Data File 86-97, 17 p.

-1986, Coal resources of the Miocene Unga Conglomera te Member, Bear Lake Formation, Unga Island, Alaska Peninsula: Alaska Division of Geological and Geophysical Surveys Public Data File 86-69, 33 p.

----1986, Evaluation of Alaska's coal potential (1982): Alaska Division of Geological and Geophysical Surveys Public Data File 86-92, 18 p.

----1986, Exploring for coal on the last frontier: Alaska Division of Geological and Geophysical Surveys Public Data File 86-89, 23 p.

---1986, Geology and coal resources of the Wood River Field, Nenana Basin: Alaska Division of Geological and Geophysical Surveys Public Data File 86-68, 37 p.

--1986, Paleoenvironmental and tectonic controls in the major coal basins of Alaska: Alaska Division of Geological and Geophysical Surveys Public Data File 86-73, 74 p.

---1986, Petrology of Cretaceous and Tertiary coals of southern Alaska: Alaska Division of Geological and Geophysical Surveys Public Data File 86-65, 49 p.

----1986, The Seward coal terminal (1985): Alaska Division of Geological and Geophysical Surveys
Public Data File 86-95, 15 p.

-1986, Western arctic coal-study proposal (1986): Alaska Division of Geological and Geophysical Surveys Public Data File 86-96, 13 p.

Merritt, R.D., Eakins, G.R., and Johnson, K.J., 1986, Proposal for entry of Alaska coal data into the National Coal Resource Data System of the U.S. Geological Survey: Alaska Division of Geological and Geophysical Surveys Public Data File 86-71, 33 p.

Merritt, R.D., Eakins, G.R., and Rawlinson, S.E., 1986, Coal and peat resource programs for Alaska: Alaska Division of Geological and Geophysical Surveys Public Data File 86-70, 27 p.

Merritt, R.D., and Hawley, C.C., 1986, Map of Alaska's coal resources: Alaska Division of Geological and Geophysical Surveys Special Report 37, scale $1: 2,500,000$.

Merritt, R.D., and McGee, D.L., 1986, Depositional environments and resource potential of Cretaceous coal-bearing strata at Chignik and Herendeen Bay, Alaska Peninsula: Alaska Division of Geological and Geophysical Surveys Public Data File 86-72, 44 p.

Morehouse, J.A., 1986, Coal bibliography of northwest Alaska: Alaska Division of Geological and Geophysical Surveys Public Data File 86-56, 33 p.

Motyka, R.J., Hawkins, D.B., Poreda, R.J., and Jeffries, W.A., 1986, Geochemistry, isotopic composition, and origin of fluids emanating from mud volcanoes in the Copper River Basin, Alaska: Alaska Division of Geological and Geophysical Surveys Public Data File 86-34, $87 \mathrm{p}$.

Motyka, R.J., Queen, L.D., Janik, C.J., Sheppard, D.S., Poreda, R.J., and Liss, S.A., 1986, Fluid geochemistry and fluid-mineral equilibria in test wells and thermal-gradient holes at the Makushin geothermal area, Unalaska Island, Alaska: Alaska Division of Geological and Geophysical Surveys Public Data File 86-59, 155 p.

Newberry, R.J., compiler, 1986, Compendium of data on skarn deposits of Alaska: Alaska Division of Geological and Geophysical Surveys Public Data File 86-17,851 p.

---1986, Mineral resources of the northcentral Chugach Mountains, Alaska: Alaska Division of Geological and Geophysical Surveys Report of Investigations 86-23, $44 \mathrm{p}$.

Ramsey, J.P., Retherford, R.M., Hickok, B., and Williams, J., 1986, Northwest coal investigations: Alaska Division of Geological and Geophysical Surveys Public Data File 86-55, 81 p.

Rawlinson, S.E., 1986, Peat-resource and surficialgeologic map of the south Kenai Peninsula, Alaska: Alaska Division of Geological and Geophysical Surveys Public Data File 86-15, scale $1: 31,680$.

Retherford, R.M., Hinderman, T.K., and Hawley, C.C., 1986, Preliminary feasibility study of a coal mine at Chicago Creek, Seward Peninsula, Alaska: Summary report: Alaska Division of Geological and Geophysical Surveys Report of Investigations 86-13, $38 \mathrm{p}$.

Robinson, M.S., 1986, Basic statistical analysis of geochemical results for rock, pan-concentrate, and stream-sediment samples from the Sleetmute A-5, A-6, B-5, and B-6 quadrangles, southwest Alaska: Alaska Division of Geological and Geophysical Surveys Public Data File 86-6, 81 p.

----1986, Tungsten and arsenic concentrations in rock, 
pan concentrate, and stream sediment samples from the Steele Creek area, northeast of Fairbanks: Alaska Division of Geological and Geophysical Surveys Public Data File 86-81, 6 p.

Sturmann, A.G., 1986, Mining-claim information for the Big Delta quadrangle, Alaska (1985), revised May 1986: Alaska Division of Geological and Geophysical Surveys Report of Investigations 86-18, $4 \mathrm{p}$.

1986, Mining-claim information for the Circle quadrangle, Alaska (1985), revised April 1986: Alaska Division of Geological and Geophysical Surveys Report of Investigations 86-19, 12 p.

--1986, Mining-claim information for the Fairbanks quadrangle, Alaska (1985), revised May 1986: Alaska Division of Geological and Geophysical Surveys Report of Investigations $86-20,8$ p.

-.---1986, Mining-claim information for the Livengood quadrangle, Alaska (1985), revised April 1986: Alaska Division of Geological and Geophysical Surveys Report of Investigations 86-21, 10 p.

Wiltse, M.A., 1986, Suggested collection methods for heavy-mineral samples: Alaska Division of Geological and Geophysical Surveys Public Data File 86-54, $11 \mathrm{p}$.

Updike, R.G., March, G.D., Allely, R.D., Krause, K.K., Jones, Doug, Nye, C.J., Long, W.E., Reeder, J.W., Carrick, S.J., Maurer, M.A., Holmes, C.E., and Davies, J.N., 1986, Engineering geology technical feasibility study, Makushin geothermal power project, Unalaska, Alaska: Division of Geological and Geophysical Surveys Public Data File 86-60, $273 \mathrm{p}$.

\section{Additional Non-Federal Publications}

Alaska Construction and Oil, 1986, Seismic sleuths search for new Cook Inlet oil: v. 27, no. 10, p. 18, 20-21.

Alaska Report, 1986, State's third diamond found northeast of Fairbanks: Petroleum Information, v. 32, no. 39, sec. 1, p. 3.

Alaska Mines and Geology [published quarterly by the State of Alaska Department of Natural Resources, P.O. Box 80007, College, AK, 99708].

Alaska Oil and Gas Conservation Commission, 1987, 1986 statistical report [available from Alaska Oil and Gas Conservation Commission, 3001 Porcupine Drive, Anchorage, AK, 99501].

American Gold News, 1986, Alaska's famous gold dredge 8 cut $4 \frac{1}{2}$ mile track and scooped up $7 \frac{1}{2}$ million ounces of gold, 1928 to 1959: American Gold News, v. 53, no. 7, p. 3 .

Babalola, O.O., 1986, Hydrocarbon exploration targets in the Ellesmerian of the National Petroleum Reserve, Alaska, from seismic stratigraphic and structural interpretations [abs.]: Geological Society of America Abstracts with Programs, v. 18, no. 6, p. 531 .

Chugach Gem and Mineral Society, 1986, Guidebook for rockhounds [available from Chugach Gem and Mineral Society, Box 92027, Anchorage, AK, 99509].

Chenowith, W.L., 1986, Developments in uranium in 1985: American Association of Petroleum Geologists Bulletin, v. 70, no. 10, p. 1632-1637.

Crawford, Mark, 1986, Interior sets fight on Alaska oil patch: Science, v. 234, no. 4782, p. 1317.

Crow, Patrick, and Williams, Bob, 1987, Arctic National Wildlife Refuge: Will it be leased or locked up?:
Oil and Gas Journal, v. 85, no. 5, p. 12-15.

Dunn, Anthony, 1986, A mineral collecting adventure in the skarn zone, Wrangell Mountains, Alaska: Rocks and Minerals, v. 61 , no. 6, p. 338-344.

Duval, David, 1986, Red Dog, Con mine see Cominco action: Northern Miner, v. 72, no. 39, p. 1-2.

Einaudi, M.T., and Hitzman, M.W., 1986, Mineral deposits in northern Alaska: Introduction: Economic Geology, v. 81, no. 7, p. 1583-1591.

Folger, P.F., 1986, The geology and geochemistry of the carbonate-hosted Omar copper deposit, Baird Mountains, Canada [abs.]: Geological Association of Canada-Mineralogical Association of CanadaCanadian Geophysical Union Joint Annual Meeting, Ottawa, Ontario, Canada, 1986, Program with Abstracts, p. 69.

Friedman, S.A., Jones, R.W., Jackson, M.L., and Treworgy, C.G., 1986, Developments in coal in 1985: American Association of Petroleum Geologists Bulletin, v. 70, no. 10, p. 1643-1649.

Geo-Heat Center, 1986, Alaska, feasibility of power production at Unalaska is under evaluation; Mt. Spurr lease sale completed: Oregon Institute of Technology, Geo-Heat Center Quarterly Bulletin, v. 9 , no. 4, p. 20.

Hilton, Don, and Mroz, T.H., 1986, Characteristics of possible reservoir rocks of methane gas hydrates: National Petroleum Reserve of Alaska [abs.]: Geological Society of America Abstracts with Programs, v. 18, no. 4, p. 292.

-----Reservoir environment of methane gas hydrate; National Petroleum Reserve in Alaska [abs.], Geological Association of Canada-Mineralogical Association of Canada-Canadian Geophysical Union Joint Annual Meeting, Ottawa, Ontario, Canada, 1986, Program with Abstracts, p. 81-82.

Hohler, J.J., and Bishoff, W.E., 1986, Alaska: Potential for giant fields, in Halbouty, M.T., ed., Future petroleum provinces of the world: American Association of Petroleum Geologists Memoir 40, p. 131-142.

Lueck, Larry, 1986, Petrologic and geochemical characterization of the Red Dog and other basemetal sulfide and barite deposits in the DeLong Mountains, western Brooks Range, Alaska: Fairbanks, University of Alaska, Mineral Industry Research Laboratory Publication 71, 105 p.

Mapmakers, 1986, Alaska oil and gas lease maps (revised ed.): [available from The Mapmakers, Star Route Box 7625, Palmer, AK 99645].

McNutt, S.R., and Jacob, K.H., 1986, Determination of large-scale velocity structure of the crust and upper mantle in the vicinity of Pavlof Volcano, Alaska: Journal of Geophysical Research, v. 91, no. B5, p. 5013-5022.

Megiris, F.A., and Sood, M.K., 1986, Trace element chemistry of Kennecott-type copper sulphides, McCarthy quadrangle, Alaska [abs.]: Geological Society of America Abstracts with Programs, v. 18, no. 4, p. 316.

Mining Journal, 1986, Alaska Apollo consolidates Shumagin claims: v. 307, no. 7879 , p. 131.

---1986, Gold: Inspiration in Alaska: v. 307, no. 7885 , p. 237.

Moore, D.W., Young, L.E., Modene, J.S., and Plahuta, J.T., 1986, Geologic setting and genesis of the Red Dog zinc-lead-silver deposit, western Brooks Range, Alaska: Economic Geology, v. 81, no. 7, p. 1696-1727.

Newkirk, S.R., and Eastoe, C.J., 1986, Sulfur isotope 
signatures of volcanogenic massive sulfide mineralization in the Delta district, east-central Alaska Range, Alaska [abs.]: Geological Society of America Abstracts with Programs, v. 18, no. 2, p. 163.

Northern Miner, 1986, Camindex takes control over Valdez Creek: v. 72, no. 3, p. 3.

----1986, Queenstake gets interest in an Alaskan property: v. 72, no. 1, p. 12.

----1986, Silverado halts production at gold mine in Alaska: v. 71 , no. 44 , p. 6 .

Oil and Gas Journal, 1986, Alaska drops two sales from leasing schedule: v. 84 , no. 29 , p. 41 .

-----1986, Alaska mulls slower leasing schedule: v. 84, no. 39, p. 34-35.

-...1986, Alaskan group backs drilling on Arctic National Wildlife Refuge: v. 84, no. 31, p. 24-25.

-1986, Amoco plans ice island wildcat in Alaskan Beaufort: v. 84, no. 2, p. 37

---1986, Leasing recommended on Alaskan wildlife area: v. 84 , no. 48, p. $32-33$.

Pacific Oil World [published monthly by Petroleum Publishers, 222 South Brea Boulevard, Brea, CA 92621].

Petroleum Information, Alaska Report [published weekly by Petroleum Information Corporation, a subsidiary of A.C. Nielsen, P.O. Box 102278, Anchorage, AK 99510].

Petroleum Information, 1986, Special report--1985 annual review--Alaska: Alaska Report, v. 32, no. 3, sec. 1, p. 5-13.

Petzet, G.A., 1986, Prudhoe Bay horizontal well yields hefty flow: Oil and Gas Journal, v. 84, no. 7, p. 4243.

Puchner, C.C., 1986, Geology, alteration, and mineralization of the Kougarok Sn deposit, Seward Peninsula, Alaska: Economic Geology, v. 81, no. 7, p. $1775-1794$.

Read, J.J., and Meinert, L.D., 1986, Gold-bearing quartz vein mineralization at the Big Hurrah Mine, Seward Peninsula, Alaska: Economic Geology, v. 81, no. 7, p. $1760-1774$.

Reeder, J.W., 1986, An analysis of fault and volcanic dike orientations for the Makushin Volcano region of the Aleutian Arc, in Reilly, W.I., and Harford, B.E., eds., Recent crustal movements of the Pacific region: Royal Society of New Zealand Bulletin 24, p. $201-212$.

Reid, J.C., 1986, Roof greisen formation at the Kougarok tin (tantalium-niobium) prospect, Seward Peninsula, Alaska [abs.]: Geological Society of America Abstracts with Programs, v. 18, no. 6, p. 727.

Rintoul, Bill, 1987, Alaska drilling/production: Pacific Oil World, v. 79, no. 1, p. 62-71.

Simmons, G.G. and Ferrell, J.E., 1986, TAPS repair shows value of deformation monitoring: Oil and Gas Journal, v. 84, no. 14, p. 79-83.

Sims, John, and Green, C.B., 1986, Mining news--good and bad: Alaska Construction and Oil, v. 27, no. 1, p. $22-25$.

Smith, S.C., 1986, Base metals and mercury in bryophytes and stream sediments from a geochemical reconnaissance survey of Chandalar quadrangle, Alaska: Journal of Geochemical Exploration, v. 25, no. 3, p. 345-365.

Sopuck, L.G., and Vernam, D.J., 1986, Distribution and movement of moose (Alces alces) in relation to the Trans-Alaska oil pipeline: Arctic, v. 39, no. 2, p. $138-144$.
Specht, R.N., Brown, A.E., Selman, C.H., and Carlisle, J.H., 1986, Geophysical case history, Prudhoe Bay field: Geophysics, v. 51, no. 5, p. 1039-1049.

Spendlove, Earl, 1986, Field trip: Nenana River jade; near Alaska's Mt. McKinley, there are rocks filled with jade!: Rock and Gem, v. 16, no. 5, p. 49-51,71.

Steefel, Carl, 1986, The Johnson River prospect, Alaska: A gold-rich "black smoker" analog from the Jurassic [abs.]: Geological Society of America Abstracts with Programs, v. 18, no. 6, p. 761.

Steenblock, L.J., 1986, Oil and gas developments in Alaska in 1985: American Association of Petroleum Geologists Bulletin, v. 70, no. 10, p. 1224-1230.

Wade, W.W., 1986, Exploration and production in Alaska: A review and forecast: World Oil, v. 2, p. 101-106.

World Oil [published monthly by Gulf Publishing Company, 3301 Allen Parkway, Houston, TX 77019].

Young, L.E., Moore, D.W., Modene, J.S., and Plahuta, J.T., 1986, Geologic setting and genesis of the Red Dog zinc, lead, and silver deposit, western Brooks Range, Alaska [abs.]: Geological Society of America Abstracts with Programs, v. 18, no. 6, p. 799.

\section{APPENDIX 2.--ROLES OF FEDERAL AGENCIES IN MINERAL PROGRAMS}

Department of the Interior

U.S. Geological Survey

The mission of the USGS is to provide information about geology, topography, and hydrology that contributes to prudent management of the Nation's natural resources. The USGS carries out its mission through research that produces geographic, cartographic, and remotely sensed information; geologic, geochemical, and geophysical maps and studies; energy-, mineral- and waterresource assessments; geohazards research, including toxic-waste studies; and participation in multidisciplinary projects, maintaining data bases, and publishing reports and maps.

In Alaska, USGS is active in assessing minerals, including metalliferous and energy resources. Field and laboratory researchers also gather information about domestic petroleum, coal, uranium, and geothermal resources. At the request of land-managing agencies, the USGS provides mineral-resource assessments for land planning, including wilderness studies.

Within Alaska, the USGS maintains offices for its Geologic, National Mapping, and Water Resources Divisions. The Branch of Alaskan Geology within the Geologic Division, which is the primary USGS office studying mineral resources in Alaska, is headquartered in Anchorage and has a field office in Fairbanks. Other Alaskan branch geologists are stationed in Menlo Park, Calif. During the summer field season, many USGS scientists from other branches within the Geologic 
Division conduct mineral-related research in Alaska.

\section{U.S. Bureau of Mines}

The mission of the USBM is to help assure that the Nation's mineral supplies are adequate to maintain national security, economic growth, and employment. The USBM's Alaska Field Operations Center (AFOC) has headquarters in Anchorage and offices in Juneau and Fairbanks. The AFOC carries out its mission through five programs:

1. Minerals Availability Program--This program is part of a worldwide USBM program responsible for developing the Minerals Availability System (MAS) computer data base and the Mineral Industry Location System (MILS), a subset of MAS. MILS contains basic information about the identification and location of known mineral deposits. MAS is more extensive, containing information about reserve estimates, mineral extraction and beneficiation methodologies, environmental constraints to mining, and cost analyses for selected major mineral deposits. A computer and communications system allows the information to be stored, manipulated, and retrieved as computer-plotted map overlays and printouts of MAS/MILS data, enabling rapid and uniform development of cost data for MAS mineral-deposit evaluations. MAS and MILS mineral-deposit data are crossindexed to several other minerals-information data bases.

2. Minerals Policy and Analysis--This program emphasizes analyses of newly developed and existing mineral data to interpret their significance relative to local and national mineral needs. Assessment of technical, institutional, political, social, and economic factors that affect the supply of and demand for domestic and international minerals is the key to identifying mineral issues.

3. State mineral activities--This program covers minerals-related activities in Alaska and assists in developing and releasing nonfuelmineral-industry information. The section of State Mineral Activities in Alaska provides USBM direct communication with industry, the Alaska Division of Geological and Geophysical Surveys and the Division of Mining, other minerals-oriented agencies, individuals, and private firms. The USBM's State Mineral Officer collects, analyzes, and reports mineral data and develops information about activities and trends in the mining industry. This program produces the annual USBM Minerals Yearbook chapters and Mineral Industry Surveys.
4. Mineral land assessment--This is the USBM's major Alaskan program, conducted in cooperation with other Federal and State agencies. Mineral assessments are both area and commodity oriented. In support of the Secretary of the Interior's commitment to assess the mineral potential of public lands in Alaska, the AFOC has begun a program to evaluate mineral resources of the mining districts in the State. The first project, initiated in 1985 in the Juneau mining district, seeks to identify the type, amount, and distribution of mineral deposits; related studies will determine ore reserves and beneficiation technologies. Studies of economic feasibility and legislative effects on mineral development will also be addressed. Studies of other mining districts will follow.

A statewide program provides an inventory and specific technical evaluations of the State's critical and strategic mineral deposits on Federal lands that are closed to mineral entry and on lands open to entry that are not of current interest to industry. In addition to locating, mapping, and estimating the size and grade of deposits, the USBM obtains bulk samples for metallurgic research to determine recovery and extraction methods and costs; these studies are undertaken in cooperation with the USBM Research Centers in Albany, Oreg., and Salt Lake City, Utah. These investigations provide reserve estimates of marginal and submarginal deposits in Alaska and its coastal waters.

5. Mining research--Mining research at the AFOC is related to mineral land-assessment activities, as well as providing assistance to alleviate problems in mining, milling and refining of ore. USBM and university research centers cooperate with the AFOC to solve mineral-utilization problems. Bulk samples of ores from various parts of Alaska have been sent to the USBM Research Centers in Albany, Oreg., and Salt Lake City, Utah, to determine characterization and beneficiation properties related to recovery of the minerals. Beneficiation is the processing of ores for the purposes of: (1) regulating the size of a desired product, (2) removing unwanted constituents, and (3) improving the quality, purity, or assay grade of a desired product.

\section{Bureau of Land Management}

The BLM is responsible for multiple-use management of both the surface and subsurface of 23 million acres of the National Petroleum Reserve in Alaska, plus an additional 76 million acres elsewhere in Alaska (see fig. 1). The second figure changes from day to day because of the 
ongoing progiam of land conveyance to State and Native organizations. In addition, the BLM administers mineral resources on approximately 100 million acres of other Federal lands, including acquired lands and private lands where the Federal Government has retained the mineral rights.

In December 1984, the BLM revised its policy statement on mineral resources to reflect its continuing commitment to encourage private enterprise to develop domestic minerals in a manner consistent with the need for these resources. Land-use planning decisions will reflect energy and mineral values addressed by mineralresource assessments. Public lands are generally to remain open to environmentally sound mineral exploration and development.

\section{Fish and Wildlife Service}

The FWS provides Federal leadership to conserve, protect, and enhance fish and wildlife and their habitats for the continuing benefit of people. In Alaska, the FWS seeks to accomplish this mission through programs that implement provisions of the Endangered Species Act, Marine Mammal Protection Act, Fish and Wildlife Coordination Act, Rivers and Harbors Act, National Wildlife Refuge System Administration Act, Alaska National Interest Lands Conservation Act (ANILCA), various migratory-bird laws and treaties, and other statutes.

Under ANILCA, 16 refuges in Alaska were created or enlarged to conserve fish and wildlife populations and their habitats, as well as other values. Except for valid rights existing at the time of establishment, these refuges are closed to entry and location under mining laws. The refuges are open to entry under leasing laws; however, they are closed to mining of Federal coal by the Federal Coal Leasing Amendments Act of 1975, and closed to geothermal-resource leasing by the Geothermal Steam Act of 1970. Although many traditional activities have been deemed appropriate for these refuges, other uses, including oil and gas leasing, will be permitted only when such activities are compatible with the purposes for which the refuges were established. Compatible uses will be determined through a comprehensive conservation planning process under way for Alaskan national wildlife refuges.

\section{National Park Service}

The act establishing the NPS (39 Stat. 535) in 1916 directed it to $1 * * *$ conserve the scenery and natural and historical objects and the wild ife * * *" and to provide for enjoyment of the same in such a manner and by such means as will leave them unimpaired for the enjoyment of future generations." Management policies are based on the concept of preservation and provide for the appropriate recreational use of natural and cultural resources within the park system. Regulation of mineral activities relate to the recognition of valid existing rights, typically mining claims that were incorporated into a particular park unit when it was established.

The NPS manages mining activities through regulations found at Title 36 , Subpart $9 \mathrm{~A}$, of the Code of Federal Regulations. These regulations apply to any mining activities on patented or valid unpatented mining claims. Any proposed plan of operations must conform to the regulations as further detailed in a "Guide to National Park Service Regulations Governing Mining and Mining Claims" (U.S. National Park Service, 1985).

\section{Department of Agriculture}

\section{U.S. Forest Service}

The mission of the USFS is to provide a continuing flow of natural-resource goods (including mineral and energy resources) and services to help meet national needs and contribute to meeting such needs worldwide. The USFS' responsibility is to encourage and support environmentally sound mineral enterprises on Federal lands under its jurisdiction, consistent with other surface-resource values. Under authority of the Forest Service Organic Act, the USFS administers regulations for the protection of surface resources from activities concerned with locatable minerals. In managing the use of these resources, the USFS ${ }^{\dagger}$ objective is that unnecessary adverse environmental impacts to surface and cultural features and values which might result from lawful prospecting operations be minimized and damages be repaired. This objective is accomplished through the application of reasonable conditions that do not interfere with legitimate, well-planned mineral operations. The USFS also provides research information and technology to help with postmining reclamation.

\section{Department of Energy}

The Federal Government's mission is to reduce the Nation's vulnerability to disruptions of energy supplies and to mitigate any adverse impacts on the Nation, should a shortage occur. With regard to Alaska, the energy sources currently being addressed by the DOE are fossil fuels (petroleum and coal) and geothermal.

The strategy for responding to petroleumsupply interruptions is to rely on the free market, supplemented as necessary and appropriate with other measures, such as the Strategic Petroleum Reserve. The DOE's Fossil Energy Research and Development Programs are aimed at careful consideration of the alternatives available and the relative chances for success in fostering an adequate supply of energy at a reasonable cost through: long-term, high-risk research and development. Alternatives for increasing domestic petroleum supplies include (1) the DOE's Unconventional Gas Recovery Program, which emphasizes the development of advanced technol- 
ogies for the extraction of natural gas from resources that are classified as unconventional because of unique geologic settings and production mechanisms which are not now well understood; and (2) DOE programs for developing tertiary oil recovery, tar sand, and heavy-oil deposits of the United States.

The purpose of the DOE's Geothermal Energy Program is to develop the technology needed by industry for the use of geothermal resources. DOE research is aimed toward improving methods used to locate, extract, and convert geothermal heat to usable forms of energy. Through DOE funding in Alaska, Federal and State agencies have researched and published several studies of specific geothermal systems.

A further purpose of DOE programs is to generate data essential to the private sector's decisionmaking process, leading to the development of commercial projects. 
